\title{
ESTUDO ORTOPANTOMOGRÁFICO DAS INCLINAÇÕES AXIAIS DOS DENTES ANTERIORES, COMPARANDO PACIENTES TRATADOS ORTODONTICAMENTE E JOVENS COM OCLUSÃO NORMAL
}

\section{RENATA RODRIGUES DE ALMEIDA}

Dissertação apresentada à Faculdade de Odontologia de Bauru, da Universidade de São Paulo, como parte dos requisitos para obtenção do título de Mestre em Odontologia, área de Ortodontia.

\section{BAURU}




\section{ESTUDO ORTOPANTOMOGRÁFICO DAS INCLINAÇÕES AXIAIS DOS DENTES ANTERIORES, COMPARANDO PACIENTES TRATADOS ORTODONTICAMENTE E JOVENS COM OCLUSÃO NORMAL}

\section{RENATA RODRIGUES DE ALMEIDA}

Dissertação apresentada à Faculdade de Odontologia de Bauru, da Universidade de São Paulo, como parte dos requisitos para obtenção do título de Mestre em Odontologia, área de Ortodontia.

(Edição Revista)

Orientador: Prof. Dr. Arnaldo Pinzan

\section{BAURU}




\begin{tabular}{|l}
\hline AL64e \\
Almeida, Renata Rodrigues de \\
Estudo ortopantomográfico das inclinações axiais dos \\
dentes anteriores, comparando pacientes tratados \\
ortodonticamente e jovens com oclusão normal / Renata \\
Rodrigues de Almeida. - Bauru, 1999. \\
144p.: il. ; $30 \mathrm{~cm}$ \\
Dissertação. (Mestrado) - Faculdade de Odontologia \\
de Bauru. USP. \\
Orientador: Prof. Dr. Arnaldo Pinzan \\
\hline
\end{tabular}

Autorizo, exclusivamente para fins acadêmicos e científicos, a reprodução total ou parcial desta dissertação, por processos fotocopiadores e/ ou meios eletrônicos.

Assinatura do autor (a):

Data: 


\section{RENATA RODRIGUES DE ALMEIDA}

17 de dezembro de 1973

Bauru SP

1992 1995

1996

1996

1998

Associações
Nascimento

Curso de Odontologia na Faculdade de Odontologia de Lins.

Professora Assistente da Faculdade de Odontologia de Lins, Disciplina de Ortodontia.

Curso de Especialização em Radiologia, na Faculdade de Odontologia de Bauru da Universidade de São Paulo.

Curso de Pós Graduação em Ortodontia, ao nível de Mestrado, na Faculdade de Odontologia de Bauru da Universidade de São Paulo.

Sociedade Paulista de Ortodontia 
Agradecimento Especial,

Ao inestimável mestre Professor Dr. Arnaldo Pinzan, eximio orientador desta pesquisa, pela compreensão, incentivo, paciência e confiança em mim depositada e também à sua familia que sempre brindowme com sua sincera amizade.

Minha admiração e meu reconhecimento. 
Agradecimento Especial,

Ao meu pai e professor Dr. Renato Rodrigues de Almeida, exemplo de humildade e dedicação, que além de transmitir seus conhecimentos na Ortodontia contribuindo para o aprimoramento de minha formação docente, sempre esteve presente nos momentos de decisão aconsethando e orientando-me.

A minha eterna gratidão. 
Agradecimento Especial,

Ao mew irmão Marcio, pela incansável ajuda, imenso carinho e paciência dispensados na elaboração e revisão deste trabalho além dos ensinamentos transmitidos durante todo meu curso de graduação e de mestrado e à minha cunhada Pati pelo apoío e amizade ofertada.

A sinceridade de minha gratidão 


\section{Agradecimentos}

Aos Professores Doutores e suas respectivas familias, Décio Rodrigues Martins, Guitherme dos Reis Pereira Janson, José Fernando Castanha Henriques, e Marcos Roberto de Freitas, pelos ensinamentos criteriosos transmitidos, pela minha formação na ciência ortodôntica e pela amizade e apoio constante não apenas durante o curso, mas em todos estes anos de convívêncía.

Ao Professor Doutor Aymar Pavarini, Diretor da Faculdade de Odontología de Baurw.

Ao Professor Doutor Luiz Fernando Pegoraro, Presidente da Comissão de Pós-Graduação da Faculdade de Odontologia de Bauru, pela oportunidade que me for concedida.

Ao Professor Doutor Marcos Roberto de Freitas, Coordenador do Curso de Pós-Graduação em 
ortodontia, ao nivel de Mestrado pelos conhecimentos transmitidos e amizade ofertada.

À amiga Maria Helena Ferreira Vasconcelos pela amizade e ensinamentos que sempre me dedicow.

Ao Pedro Pauto (Peo) pelos ensinamentos no Curso de Ortodontia Preventiva e pelos anos de convivêncía.

Aos amigos Dani e Danito pela sinceridade de suas amizades em todos esses anos de convivência, peta paciência, carinho e atenção a mim dedicada durante todo o curso de graduação e de pós.

Aos amigos do Curso de Mestrado, Ana Carla, Ana Cláudia, Dani, Fausto, Karina, Karyna, Pauto e Roberto, por todos os bons momentos de convívio, pela estima e colaboração durante o curso. 
Aor Colegas do antigo Doutorado, Marcinha, Eduardo, Jorge e Pedro Paulo, pela amizade e auxítio nas autas laboratoriais.

Aos Funcionários da Disciplina de Ortodontia, Verinha, Sérgio, Tía Maria, Cristina, Cristiane e Daniel, que sempre me acotheram e me ajudaram dispensando atenção, carinho e amizade.

Ao Daniel que, com todo capricho, ajudou na confecção das figuras deste trabalho.

A Verinha que não mediu esforços para que esta pesquisa fosse entregue dentro do prazo e ao Sérgio pelas incansáveis horas de bate-papo.

Ao Professor José Martha e a tia Sara que, com atenção, executaram of testes estatisticos $e$ me orientaram e também pela amizade de tantos anos.

Ao Professor Doutor Guitherme dos Reis Pereira Janson peto auxitio na elaboração do Abstract. 
Ao Professor Doutor Orívaldo Tavano pelos ensinamentos a mim oferecidos.

Aos funcionários da biblioteca, especialmente à Rita e à Valéría, pelas constantes orientações e pelo zelo nos serviços prestados.

Aos funcionários da Discíplina de Radiologia, em especial ao Celinho e à Walderez pela amizade $e$ prontidão no atendimento durante $\sigma$ curso de especiatização e de mestrado.

Aos meus pacientes, indispensáveis à minha formação profissional e ao mew aprendizado.

Aos funcionários da Pós-Graduação Neide, Gíane, Cleuza, Ana, Heloisa e Aurélio pela constante cordiatidade.

À CAPES pela concessão da bolsa de estudo. 


\section{SUMÁRIO}

LISTA DE FIGURAS

LISTA DE TABELAS

RESUMO

1 INTRODUÇÃO

2 REVISÃO DE LITERATURA

2.1 CONSIDERAÇÕES SOBRE A TÉCNICA E TERMINOLOGIA DA RADIOGRAFIA PANORÂMICA COMO MÉTODO AUXILIAR EM ORTODONTIA

2.2 INCLINAÇÃO AXIAL MESIODISTAL - CONSIDERAÇÕES SOBRE OS ASPECTOS ANATÔMICOS; OCLUSAIS E ORTODÔNTICOS...................................................................... 50

3 PROPOSIÇÃO …................................................................... 70

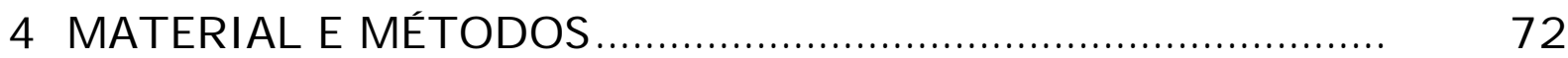

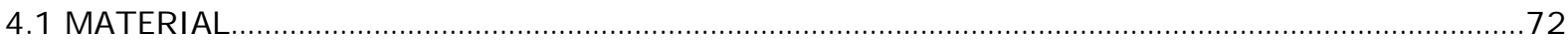

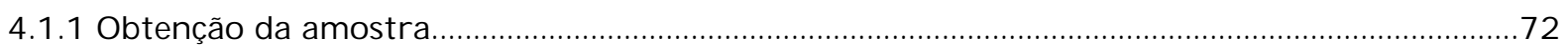

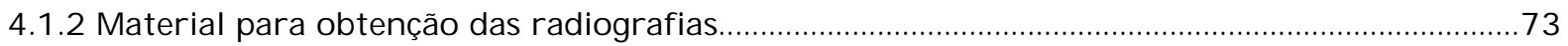

4.1.3 Material para elaboração dos traçados e mensuração dos ângulos ..............................................74

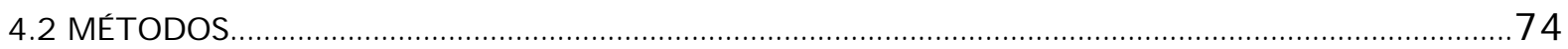

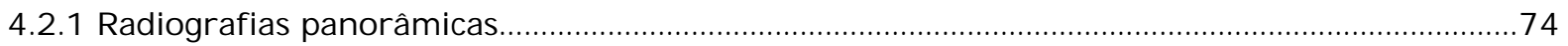

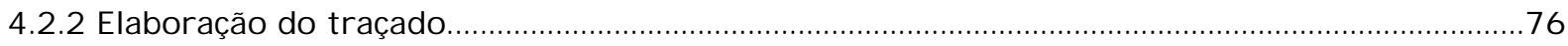

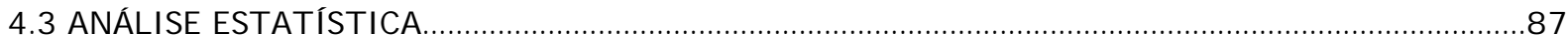

4.4 ERRO DO MÉTODO

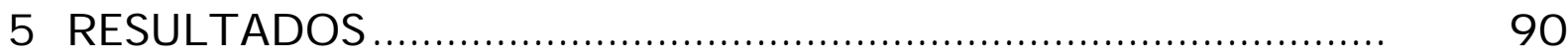

6 DISCUSSÃO …...................................................................... 100

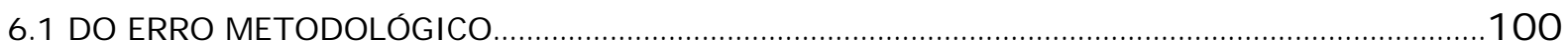

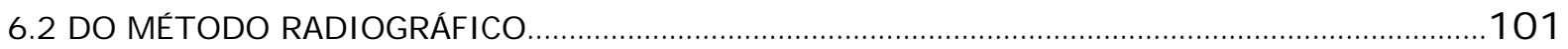

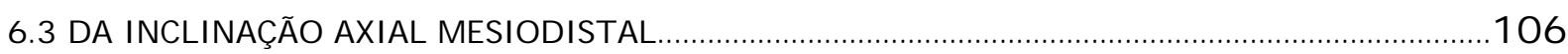

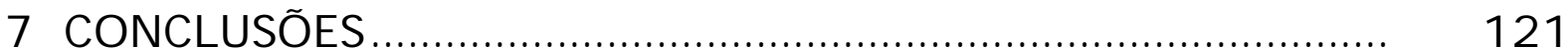

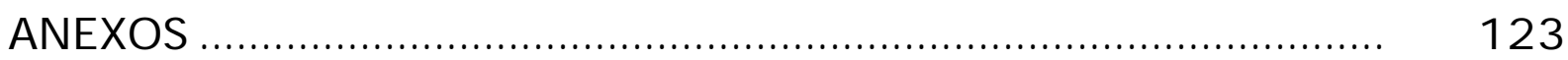

REFERÊNCIAS BIBLI OGRÁFICAS .............................................. 126

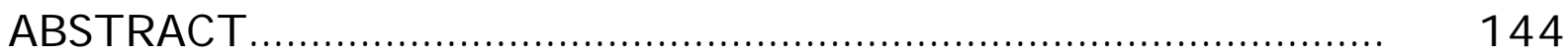




\section{LISTA DE FIGURAS}

FIGURA 1- Esquema de funcionamento dos aparelhos com um centro de rotação

FIGURA 2- Esquema de funcionamento do aparelho Panorex, que utiliza o princípio excêntrico, de dois centros de rotação

FIGURA 3- Esquema de funcionamento do aparelho Panoramax, que utiliza o princípio concêntrico e excêntrico, de três centros de rotação

FIGURA 4- Esquema de funcionamento dos aparelhos elipsopantomográficos, que utilizam o princípio do movimento contínuo do centro de rotação

FIGURA 5- Aparelho radiográfico e correto posicionamento do paciente

FIGURA 6- Desenho anatômico das estruturas dentoesqueléticas

FIGURA 7- Pontos de referência

FIGURA 8A- Linhas de referência horizontais

FIGURA 8B- Linhas de referência verticais

FIGURA 9A- Ângulos formados pelos longos eixos dos dentes superiores e a linha interorbitária

FIGURA 9B Ângulos formados pelos longos eixos dos dentes inferiores e a linha intermentoniana

FIGURA 10- Desenho anatômico com pontos, linhas e ângulos de interesse

FIGURA 11- Radiografia panorâmica inicial e final, com traçado, de um mesmo paciente da amostra 
FIGURA 12- Representação gráfica da correlação entre o valor médio em T1 e médio em T2 para os caninos inferiores e superiores

FIGURA 13- Representação gráfica da correlação entre o valor médio em T1 e médio em T2 para os incisivos superiores

FIGURA 14- Representação gráfica da correlação entre o valor médio padrão e médio em T1 para os caninos inferiores e superiores

FIGURA 15- Representação gráfica da correlação entre o valor médio padrão e médio em T1 para os incisivos superiores

FIGURA 16- Representação gráfica da correlação entre o valor médio padrão e médio em T2 para os caninos inferiores e superiores

FIGURA 17- Representação gráfica da correlação entre o valor médio padrão e médio em T2 para os incisivos superiores

FIGURA 18- Representação gráfica da correlação entre o valor médio padrão, médio em T1 e em T2 para os caninos inferiores e superiores

FIGURA 19- Representação gráfica da correlação entre o valor médio padrão, médio em T1 e em T2 para os incisivos superiores 


\section{LISTA DETABELAS}

TABELA 1- Média e desvio-padrão das diferenças, valor de $t$ (erro sistemático), níveis de probabilidade de significância (P) e índice de Dahlberg (erro casual) dos valores obtidos da comparação entre as duas séries de traçados das radiografias panorâmicas iniciais ( $\mathrm{T} 1$ )

TABELA 2- Média e desvio-padrão das diferenças, valor de t (erro sistemático), níveis de probabilidade de significância (P) e índice de Dahlberg (erro casual) dos valores obtidos da comparação entre as duas séries de traçados das radiografias panorâmicas finais (T2)

TABELA 3- Média e desvio-padrão, em graus, das inclinações axiais mesiodistais dos dentes ântero-superiores e caninos inferiores, obtidos das radiografias panorâmicas ao início do tratamento ortodôntico (T1)

TABELA 4- Média e desvio-padrão, em graus, das inclinações axiais mesiodistais dos dentes ântero-superiores e caninos inferiores, obtidos das radiografias panorâmicas ao término do tratamento ortodôntico (T2)

TABELA 5- Média e desvio-padrão das diferenças, graus de liberdade, valor de $\mathrm{t}$ e níveis de probabilidade de significância (P) dos valores obtidos das radiografias panorâmicas ao início (T1) e ao término do tratamento ortodôntico (T2)

TABELA 6- Valores médios normais (padrão) das inclinações axiais mesiodistais de cada dente individualmente, médias dos valores obtidos ao início do tratamento ortodôntico (T1) e níveis de probabilidade de significância (P) 
TABELA 7- Valores médios normais (padrão) das inclinações axiais mesiodistais de cada dente individualmente, médias dos valores obtidos ao término do tratamento ortodôntico (T2) e níveis de probabilidade de significância (P)

TABELA 8- Valores médios normais (padrão) das inclinações axiais mesiodistais de cada dente individualmente, médias dos valores obtidos ao início (T1) e ao término do tratamento ortodôntico (T2) 


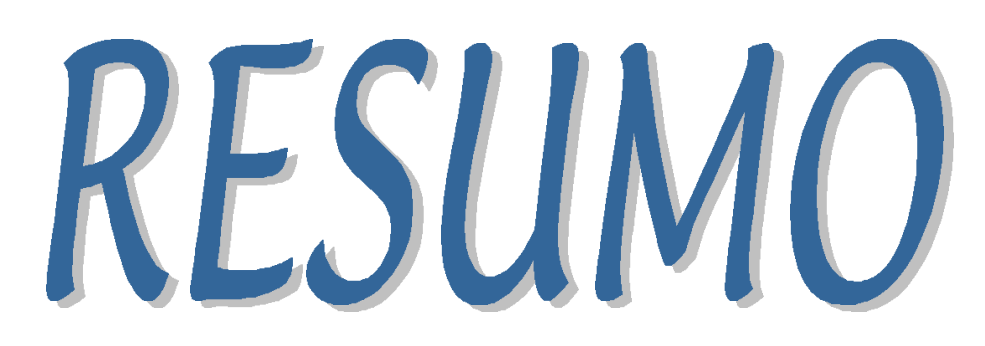




\section{RESUMO}

Este estudo objetivou avaliar, por meio das radiografias panorâmicas, as inclinações axiais mesiodistais dos dentes ântero-superiores e caninos inferiores ao início e ao término do tratamento ortodôntico. A amostra constituiu-se de 80 radiografias panorâmicas, sendo uma inicial (T1) e outra final (T2) de 40 jovens, de ambos os sexos, tratados ortodonticamente, sem extrações, com a técnica edgewise simplificada. Compararam-se os valores médios das inclinações axiais mesiodistais em T1 com os valores médios em T2 e os valores médios em T1 e em T2 com os médios normais. Os resultados demonstraram que, ao início do tratamento, as inclinações axiais mesiodistais dos dentes ântero-superiores e caninos inferiores apresentaram-se, em 50\% dos dentes avaliados, diferentes daquelas observadas em uma oclusão normal. As inclinações, ao final do tratamento, mostraram-se em sua maioria, concordes com as configurações anatômicas normais. Observou-se também que a radiografia panorâmica apresentou-se como um valioso instrumento para avaliar as inclinações mesiodistais dentárias antes e durante o tratamento, denotando a necessidade de correção ou apenas da manutenção da inclinação axial mesiodistal, de forma a proporcionar, estabilidade e oclusão funcional adequadas. 


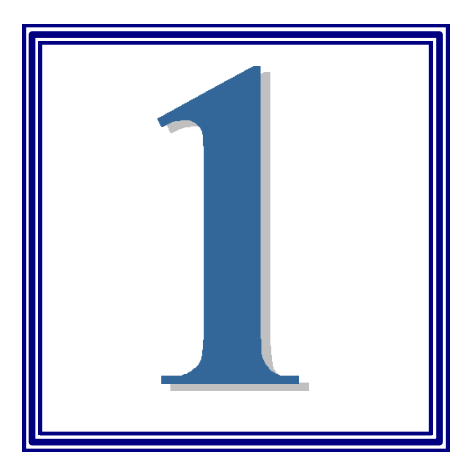

INTRODUÇÃO 


\section{1 - INTRODUÇÃO}

Desde os primórdios da ortodontia, no que tange aos meios de diagnóstico e planificação do tratamento e ao desenvolvimento de técnicas e materiais ortodônticos de última geração, uma das maiores preocupações dos pesquisadores centralizou-se na normalização da oclusão dentária e das funções bucais dos pacientes ao final do tratamento.

O conceito de normalidade, atribuído àquelas posições dentárias características dos indivíduos, brindados pela natureza, com oclusão ótima não tratada, foi brilhantemente descrito por ANDREWS ${ }^{10}$ tornando-se um clássico da literatura, estabelecendo uma nova era na ortodontia mundial. Dentre as seis chaves para uma oclusão normal, destaca-se a inclinação axial mesiodistal.

O correto posicionamento mesiodistal dos longos eixos dentários, contribui sobremaneira para alcançar o equilíbrio da oclusão e do sistema estomatognático, constituindo-se num fator relevante para a obtenção do perfeito alinhamento dos dentes em suas respectivas bases ósseas e para a manutenção da estabilidade dos resultados 
obtidos pelo tratamento ortodôntico ${ }^{11,32,48}$. Este parâmetro, um dos adotados clinicamente para definir a excelência de um caso bem terminado, é atualmente observado na radiografia panorâmica 22,23,90,91 que proporciona condições satisfatórias para a avaliação do posicionamento dentário antes, durante e após a terapia ortodôntica.

Dentre os diversos elementos necessários para a composição de uma documentação ortodôntica, a radiografia panorâmica ocupa um lugar de destaque permitindo ao ortodontista a visualização de todos os dentes e respectivas bases ósseas, em uma única exposição ${ }^{7,35}$.

Em vista da grande popularidade da radiografia panorâmica e das diversas possibilidades de seu emprego em ortodontia $1,2,5,6,14,15,19,22,34,37,40,43,45,46,47,49,54,55,56,65,67,85,90,91,97$, objetivou-se avaliar as inclinações axiais mesiodistais dos dentes ântero-superiores e caninos inferiores de pacientes tratados ortodonticamente com a técnica edgewise simplificada, ao início e ao término do tratamento e compará-las aos valores médios normais, propostos por URSI ${ }^{90}$. 


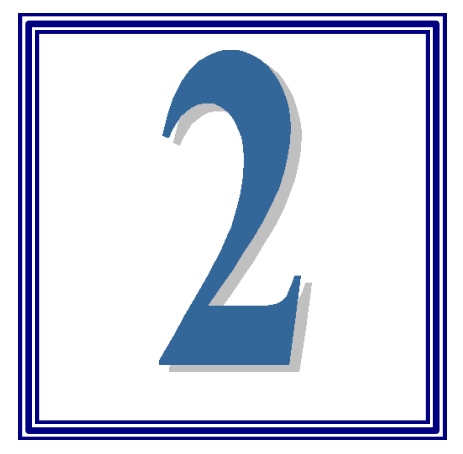

REVISÃO DE LITERATURA 


\section{2- REVISÃO DE LITERATURA}

Com a finalidade de facilitar a compreensão e a inter pretação dos resultados desta pesquisa, dividiu-se a revisão de literatura em duas partes distintas concernentes aos estudos correlacionados ao tema:

2.1 - Considerações sobre a técnica e terminologia da radiografia panorâmica como método auxiliar em ortodontia;

2.2 - Inclinação axial mesiodistal - considerações sobre os aspectos anatômicos, oclusais e ortodônticos.

\section{1 -CONSI DERAÇÕES SOBRE A TÉCNICA E TERMINOLOGIA DA RADIOGRAFIA PANORÂMICA COMO MÉTODO AUXILIAR EM ORTODONTIA}

Preliminarmente cumpre-nos esclarecer a grande diversidade de termos existentes para se referir às radiografias panorâmicas. Com o intento de não prejudicar a compreensão dos textos revisados, optou-se por discorrer sucintamente sobre esta divergência terminológica. 
Os termos pantomografia, pantomograma, ortopantomografia, radiografia ortopantomográfica, ortopantomograma, panoramografia, radiografia rotatória, elipsopantomografia, elipsopantomograma e radiografia panorâmica, todos sinônimos, são utilizados para designar a técnica radiográfica que permite a visualização de toda a região maxilomandibular e estruturas adjacentes, com uma ou no máximo duas exposições ${ }^{7,36}$.

Várias técnicas foram propostas para proporcionar uma visão panorâmica das estruturas dentárias em apenas uma radiografia. Na revisão da literatura nota-se a preocupação constante dos pesquisadores, no sentido de aprimorar os aparelhos panorâmicos. Estes aparelhos apresentam dois procedimentos básicos de funcionamento: procedimentos estáticos ou não tomográficos e procedimentos dinâmicos ou tomográficos ${ }^{7,36}$.

Os aparelhos panorâmicos que utilizam os princípios tomográficos, classificam-se de acordo com os eixos de rotação ${ }^{7,36} \mathrm{em:}$

1-aparelhos com um centro de rotação = Rotagraph, Panograph e Panographix (figura 1, página 8); 
2-aparelhos com dois centros de rotação = Panorex (figura 2, página 9);

3-aparelhos com três centros de rotação = Orthopantomograph (ortopantomógrafo), Panoura, Panoramix (figura 3, página 10) e

4-aparelhos com centro rotacional móvel = Panelipse, Orthophos, Panex-E (figura 4, página 11).

Os aparelhos panorâmicos, muitas vezes incorporam ao nome comercial os princípios de funcionamento. Assim, as radiografias obtidas no primeiro aparelho desenvolvido com três centros de rotação de marca comercial Orthopantomograph, ficaram conhecidas como ortopantomografias, ortopantomogramas ou radiografias ortopantomográficas. No entanto, muitos utilizam estes termos para se referirem às radiografias obtidas em aparelhos com outros princípios de funcionamento. Os aparelhos com centro rotacional móvel podem ser denominados de elipsopantomógrafos e então, a radiografia assim obtida é conhecida como elipsopantomografia. Contudo, as imagens radiográficas oriundas de todos estes aparelhos podem receber qualquer uma das terminologias aqui descritas, no entanto, preferimos o termo radiografia panorâmica. 


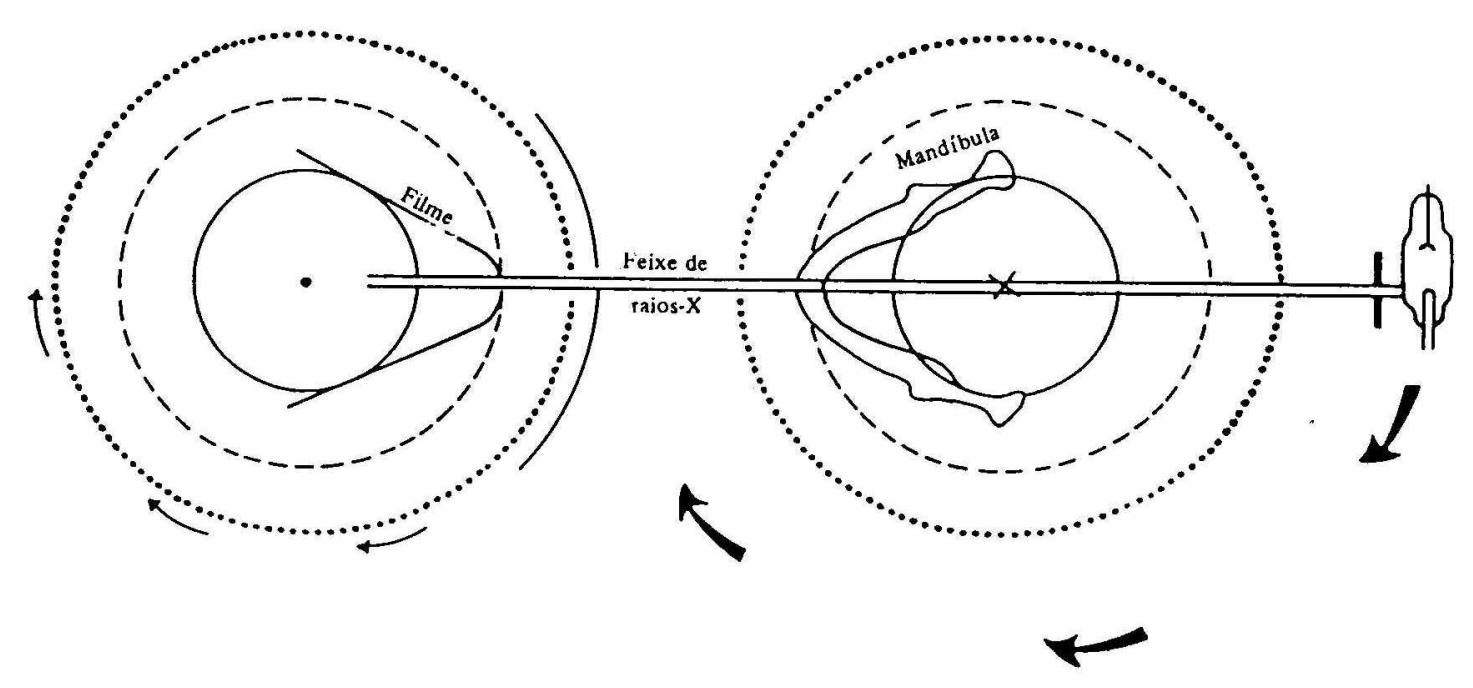

FIGURA 1- Esquema de funcionamento dos aparelhos com um centro de rotação (de acordo com ALVARES, L.C.; TAVANO, 0. Curso de radiologia em odontologia. 3.ed. São Paulo, Editora Santos, 1993) ${ }^{7}$. 


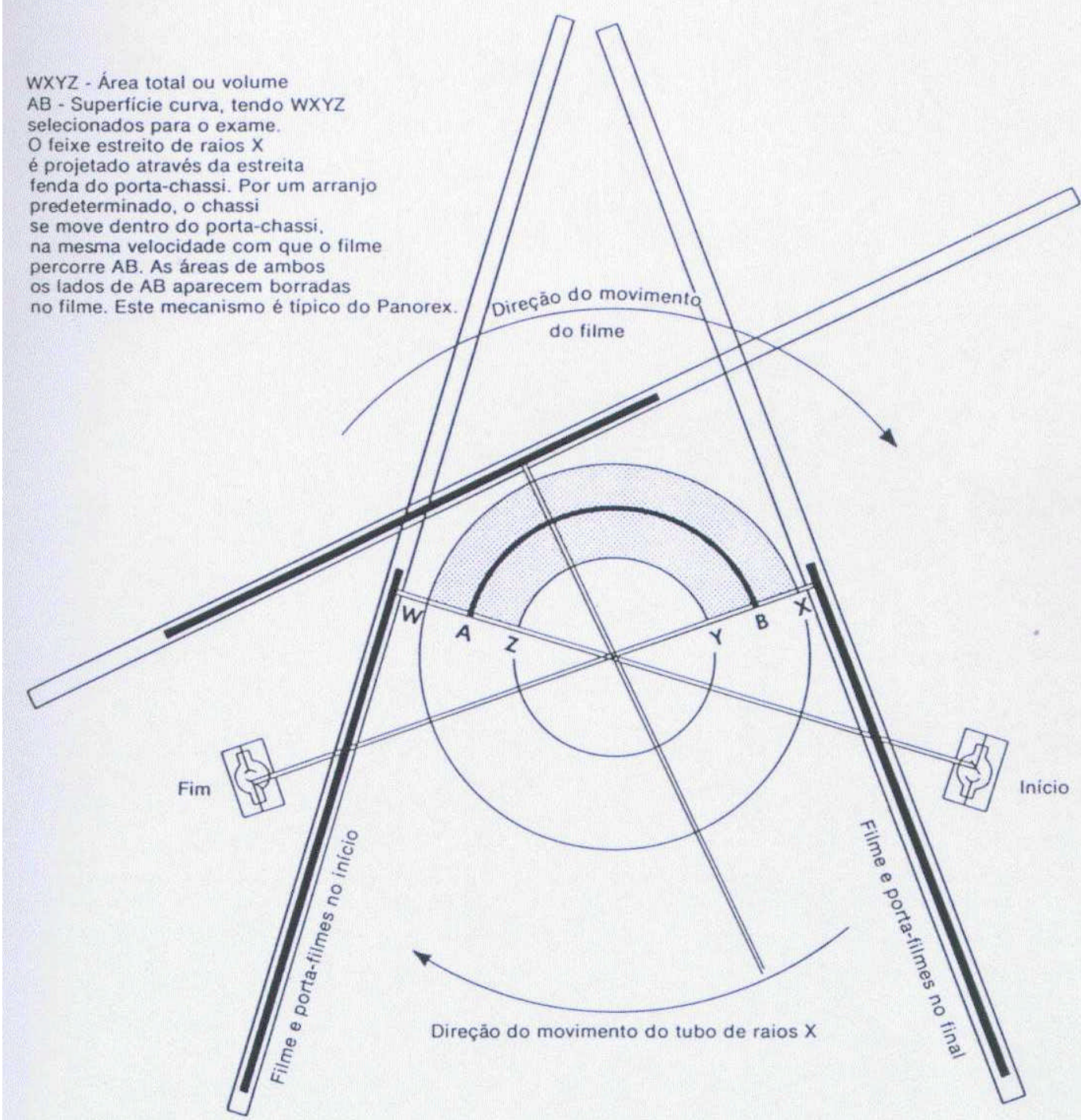

FIGURA 2- Esquema de funcionamento do aparelho Panorex, que utiliza o princípio excêntrico, de dois centros de rotação (de acordo com FREITAS, A.; ROSA, J.E.; SOUZA, I.F. Radiologia odontológica. 4.ed. São Paulo, Artes Médicas, 1998) ${ }^{36}$. 


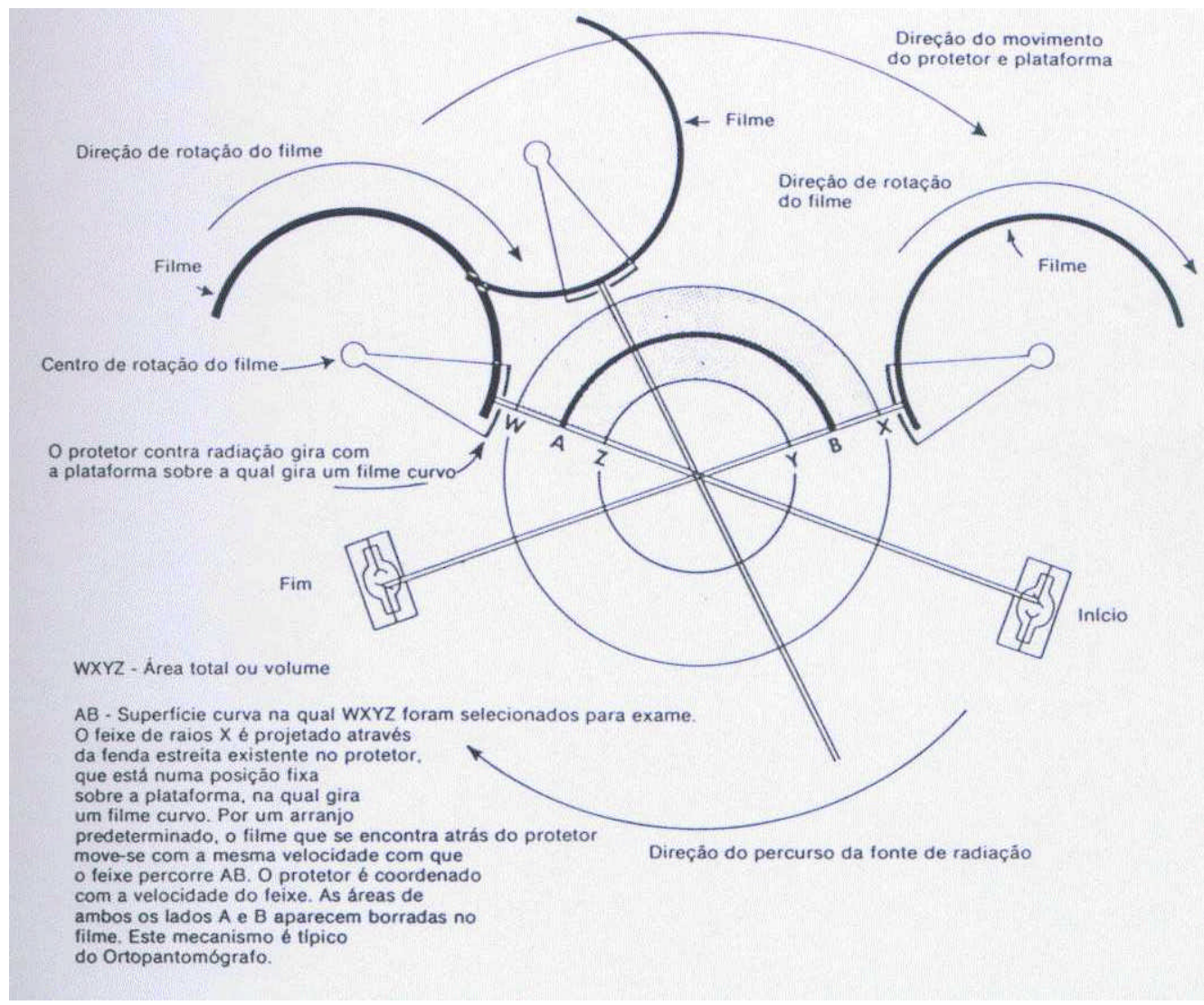

FIGURA 3- Esquema de funcionamento do aparelho Panoramax, que utiliza o princípio concêntrico e excêntrico, de três centros de rotação (de acordo com FREITAS, A.; ROSA, J.E.; SOUZA, I.F. Radiologia odontológica. 4.ed. São Paulo, Artes Médicas, 1998) ${ }^{36}$. 


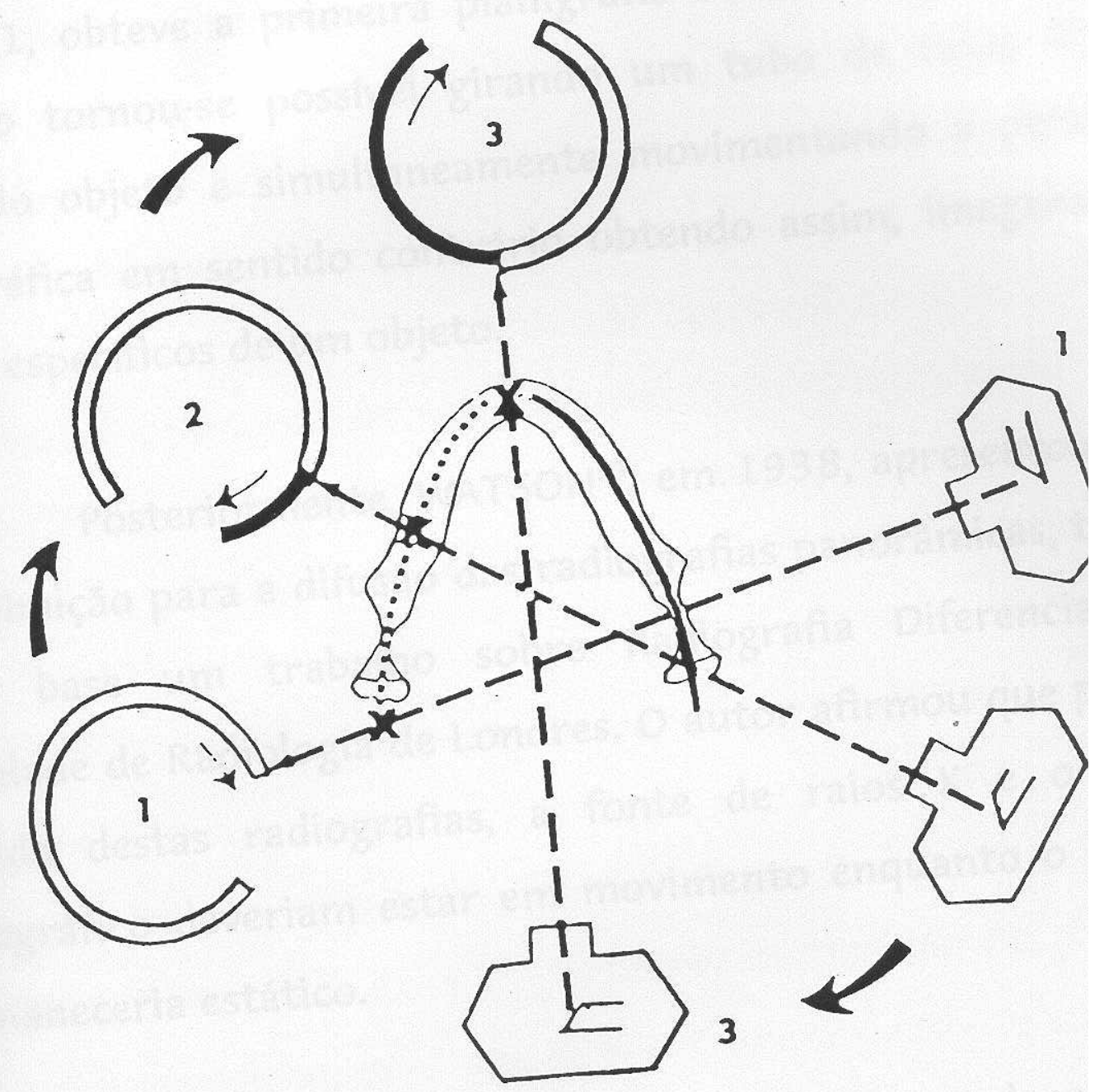

FIGURA 4- Esquema de funcionamento dos aparelhos elipsopantomográficos, que utilizam o princípio do movimento contínuo do centro de rotação (centro rotacional móvel) (de acordo com ALVARES, L.C.; TAVANO, O. Curso de radiologia em odontologia. 3.ed. São Paulo, Editora Santos, 1993)7. 
O precursor da técnica radiográfica panorâmica segundo ANDREWS ${ }^{9}$, foi Bocage, um pesquisador francês, que em 1921, obteve a primeira planigrafia ou laminografia. Este processo tornou-se possível girando um tubo de raios $\mathrm{X}$ ao redor do objeto e simultaneamente movimentando a película radiográfica em sentido contrário obtendo assim, imagens de planos específicos de um objeto.

Posteriormente, WATSON ${ }^{93}$, em 1938, apresentou sua contribuição para a difusão das radiografias panorâmicas, tendo como base um trabalho sobre Radiografia Diferencial da Sociedade de Radiologia de Londres. O autor afirmou que para a tomada destas radiografias, a fonte de raios $X$ e 0 filme radiográfico deveriam estar em movimento enquanto o objeto permaneceria estático.

Durante quase dez anos, as pesquisas envolvendo esta nova técnica radiográfica foram suspensas em função da segunda grande guerra mundial, quando a Europa e quase todos os outros países mundiais envolveram-se no conflito. Ao término da guerra, a Finlândia, a França, a Inglaterra e os Estados Unidos voltaram a trabalhar no desenvolvimento de experimentos com estas radiografias rotatórias. 
Finalmente, retomando os experimentos com a nova técnica radiográfica, em 1948, o finlandês PAATERO ${ }^{70}$, apresentou a primeira publicação científica da aplicação da pantomografia, processo que registra na película radiográfica uma imagem nítida de uma superfície curva. Este termo utilizado pelo autor, é a contração das palavras panorâmica e tomografia. Dois anos mais tarde ele desenvolveu o protótipo do primeiro aparelho, obtendo a primeira radiografia de uma pessoa. Todos aparelhos panorâmicos tomográficos existentes no mercado, praticamente, derivam dos estudos de PAATERO ${ }^{70}$.

O interesse despertado em vários pesquisadores pelo aprimoramento da técnica implantada por PAATERO ${ }^{70}$ resultou em novos estudos e publicações científicas. Em 1952, NELSEN; KUMPULA ${ }^{69}$ constataram a importância da posição do paciente durante a exposição, para que se mantivesse constante a relação filme, objeto e fonte de radiação. Contudo, sabe-se que isto não é possível, uma vez que as estruturas dentárias de cada paciente variam em função da forma e do tamanho do arco dentário. O diagnóstico e controle da cárie em populações numerosas foi considerado pelos autores a maior vantagem desta técnica. 
Ainda com relação ao posicionamento do paciente no aparelho, PAATERO ${ }^{71}$, no ano de 1954, verificou que a imagem obtida apresentava-se melhor quando o plano de Frankfurt encontrava-se paralelo ao plano do solo, porém clinicamente a utilização do plano de Camper também era aceitável. O pantomógrafo, consistia de uma cadeira motorizada, um portafilme giratório e uma fonte de raios $X$ estacionária. Para obtenção de uma pantomografia de uma estrutura curva, dobrava-se a película no formato do arco dentário e, esta e o paciente giravam com a mesma velocidade de deslocamento angular, porém em direções opostas.

Dois anos mais tarde BLACKMAN ${ }^{15}$ constatou que a exemplo dos outros tipos de radiografias, os aparelhos panorâmicos também produziam imagens sempre maiores que o objeto, contando com um aumento adicional no sentido horizontal. Corroborando com a opinião de PAATERO ${ }^{71}$, o autor afirmou que o contorno dado ao porta-filme deveria ser o mais próximo possível à forma dos arcos dentários, e que os planos de referência utilizados para o posicionamento do paciente seriam o plano de Camper ou o de Frankfurt. BLACKMAN ${ }^{15}$ defendia a idéia do aperfeiçoamento do aparelho para a realização de estudos longitudinais sobre o desenvolvimento da 
oclusão, pois nesta tomada radiográfica podia observar todo o complexo dentoalveolar.

Os estudos relacionados às radiografias panorâmicas foram cada vez mais difundidos na literatura científica. No ano de 1960, BLACKMAN ${ }^{16}$ esclareceu seus princípios básicos e seu funcionamento, descrevendo-a como um meio simples e rápido para examinar as estruturas ósseas e dentárias de pacientes de qualquer idade, e que por isso, deveriam ser usadas rotineiramente.

O ápice das pesquisas de PAATERO ${ }^{72}$ ocorreu em 1961, com o desenvolvimento do ortopantomógrafo, que melhorou sobremaneira a produção da imagem, pois os aparelhos anteriores com apenas um ou dois eixos de rotação forneciam uma imagem com qualidade bem inferior a este, com três eixos de rotação independentes. Este mecanismo propiciou uma radiografia de toda a região maxilomandibular projetada de maneira ortorradial (perpendicular).

Com o aparelho desenvolvido, utilizando os mesmos princípios de funcionamento que os atuais, iniciou-se uma fase de pesquisas sobre a qualidade da imagem radiográfica, 
principalmente as que se referem às distorções angulares e lineares.

A quantidade de radiação e distorções lineares da imagem fornecida por um aparelho de marca comercial Panorex, preocuparam KITE et al. ${ }^{57}$ que em 1962, realizaram um experimento avaliando três grupos de radiografias. No grupo 1, observaram a imagem radiográfica produzida por uma tela metálica com a forma de uma mandíbula; no grupo 2 realizaram medições similares em crânios humanos e no grupo 3 utilizaram películas de vários pacientes. Concluíram que a distorção da imagem ocorria devido a três fatores: 1) pelo posicionamento inadequado do paciente, durante a exposição; 2) devido à movimentação do paciente durante a tomada radiográfica e 3) por assimetrias ou discrepâncias na largura dos maxilares. Os autores ressaltaram ainda que a grande vantagem deste método radiográfico consistia na obtenção da imagem de todos os dentes e estruturas adjacentes em uma única radiografia, com uma dose de radiação biologicamente bastante aceitável para o paciente.

Neste mesmo ano, GILBERT ${ }^{40}$ ocupou-se com a viabilidade de se utilizar, em ortodontia, radiografias 
panorâmicas obtidas com um aparelho da marca Panorex. No seu trabalho evidenciou que na região dos molares ocorriam as maiores distorções lineares, porém o posicionamento adequado do paciente podia reduzir este inconveniente. Destacou como vantagem da técnica o fato de permitir uma visualização das relações entre as coroas e as raízes dentárias com as estruturas ósseas, existindo uma acuidade angular e linear capazes de torná-la um instrumento confiável nas pesquisas clínicas.

Novamente utilizando radiografias panorâmicas obtidas em um aparelho Panorex, MITCHELL ${ }^{67}$ em 1963, empreendeu um estudo clínico utilizando uma amostra de 100 radiografias de pacientes de diferentes idades que foram avaliadas por 20 Cirurgiões-dentistas, especialistas em diferentes áreas da Odontologia. As conclusões revelaram que a radiografia panorâmica constitui um meio de diagnóstico suficientemente adequado para a maioria dos exames clínicos de rotina, mostrando com clareza os diferentes estágios de desenvolvimento e irrupção dentária, porém, apresenta ínfima propriedade de detecção de cáries incipientes ou detalhes mais acurados, sendo aconselhável uma complementação com radiografias interproximais ou periapicais. 
Com o enfoque voltado para as vantagens e limitações das radiografias panorâmicas, BLACKMAN ${ }^{17}$ em 1963, demonstrou que devido ao formato dos arcos dentários e ao contorno da face, os resultados obtidos por esta técnica apresentavam distorções nas imagens dos dentes, com superposição de algumas estruturas adjacentes. Por outro lado, citou como vantagens: a possibilidade de visualização total dos arcos dentários, da articulação temporomandibular, dos ossos e arcos zigomáticos, das órbitas, da cavidade nasal; a utilidade na análise comparativa das assimetrias faciais, além de fornecer uma boa visualização da anatomia mandibular, oferecendo condições de avaliar fraturas e lesões patológicas extensas.

Dando continuidade à divulgação das radiografias panorâmicas nas diversas áreas da odontologia, KANE ${ }^{55}$ (1964) encetou seu uso no estudo do padrão de desenvolvimento e erupção dos dentes, tendo relatado também que esta poderia ser usada com sucesso nas mensurações das alterações da crista alveolar, no acompanhamento dos processos de destruição ou reparo ósseo e na avaliação da movimentação ortodôntica, permitindo observações referentes à quantidade de força empregada, idade do paciente, tipo de aparelho entre outros aspectos. 
Na tentativa de levar aos clínicos mais conhecimentos sobre as vantagens e as limitações das radiografias panorâmicas, em 1965, GRABER ${ }^{43}$ alertou sobre a freqüência com que ocorrem sobreposições e indefinições na imagem radiográfica da região dos primeiros pré-molares, devido aos fatores mecânicos do funcionamento do aparelho e à posição destes dentes no arco. Outras variáveis devem ser também observadas, tais como a forma do crânio e do arco dentário. Por outro lado, o autor incentivou o uso das radiografias panorâmicas nos estudos do padrão de irrupção dentária, na detecção de reabsorções patológicas, no diagnóstico de anomalias de número, forma e de posição, no acompanhamento do progresso do tratamento ortodôntico expondo a "disposição radicular" e nos casos de extração seriada mostrando as relações entre os dentes decíduos e os permanentes.

Objetivando uma continuidade nesta linha de pesquisa, GRABER ${ }^{45}$, no ano seguinte, afirmou que a obtenção da radiografia panorâmica, tornou-se imprescindível em fases intermediárias do tratamento ortodôntico ativo, no sentido de acompanhar as respostas teciduais ao nível do processo alveolar. Enfatizou também sua importância na verificação da espessura da membrana periodontal, da integridade do tecido 
ósseo ao redor dos dentes, do trajeto de irrupção dos terceiros molares e do paralelismo das raízes, principalmente daquelas próximas aos locais das extrações, obtendo, desta forma, um adequado acompanhamento do caso e dos objetivos da correção ortodôntica.

Ao avaliar os princípios mecânicos de um ortopantomógrafo, no ano de 1967, PHILLIPS ${ }^{74}$ concluiu que todas as imagens obtidas apresentavam um aumento dimensional de todas estruturas, devido aos fatores geométricos da formação da imagem. Contudo, o autor advogou seu uso citando vantagens como a simplicidade de operação do aparelho, tempo de exposição reduzido com menor radiação ao paciente, visualização do desenvolvimento da dentição e de lesões, além da boa aceitação dos pacientes, inclusive os excepcionais.

No mesmo ano, visando melhorar o posicionamento do paciente para a tomada de radiografias panorâmicas, KANE ${ }^{56}$ desenvolveu um cefalostato, adaptando-o a um aparelho da marca comercial Panorex. Com este dispositivo, o autor testou a capacidade de reprodução da posição do paciente, realizando algumas medições lineares, em duas tomadas radiográficas. Com 
os resultados obtidos concluiu-se que a comparação das alterações das posições dentárias, do paralelismo radicular, da angulação, antes e após o tratamento ortodôntico, do nivelamento dentário e da perda de ancoragem, tornaram-se possíveis com a introdução deste instrumento.

Inter essado na utilização da radiografia panorâmica para o diagnóstico ortodôntico, $\operatorname{GRABER}^{46}$ (1967), destacou a precariedade desta radiografia na avaliação precisa das deficiências no comprimento do arco dentário e na observação do espaço presente para a irrupção dos caninos e pré-molares. Afirmou ainda que, com o aumento do tamanho do objeto e a diminuição do detalhe especialmente na região dos incisivos, causada pela superposição da coluna vertebral, ocorre uma falta de uniformidade na imagem entre esta região e a região dos pré-molares. Entretanto, este meio de diagnóstico apresentou uma validade ímpar na evidenciação das más oclusões transitórias, durante a esfoliação dos dentes decíduos e a irrupção dos permanentes e no estudo do desenvolvimento da oclusão.

Em 1968, LANGLAND; SIPPY58, estudaram as distorções nos ortopantomogramas nos planos horizontal e 
vertical, e concluíram que era possível minimizá-las alinhando-se o plano sagital do paciente com a linha de referência do suporte mentoniano do aparelho, ficando a borda inferior da mandíbula eqüidistante do suporte mentoniano e o plano oclusal do paciente paralelo ao solo. Observaram também, distorções verticais da ordem de $31,7 \%$ e horizontais de 30 a $46 \%$.

No mesmo ano, ISHIKAWA ${ }^{53}$, ao comentar a importância das radiografias panorâmicas em ortodontia, citou como vantagens da técnica, a simplicidade de obtenção, menor quantidade de radiação quando comparada com um levantamento periapical completo, a possibilidade de visualização das articulações temporomandibulares, de todos os dentes e dos processos alveolares, ainda aliadas ao conforto que oferece ao paciente de todas as idades. Entretanto, considerou como desvantagens a perda de detalhes de certas estruturas e a presença de distorções, contudo enfatizou seu uso como meio auxiliar de diagnóstico em ortodontia incluindo todas as fases do tratamento ativo e de contenção.

No intuito de averiguar o padrão de distorção da imagem proporcionada pelo aparelho da marca Panorex, em 1968, CHRISTEN; SEGRETO ${ }^{28}$ realizaram uma pesquisa, 
utilizando uma mandíbula seca, com marcadores metálicos, posicionada de diferentes maneiras em um cefalostato. Concluíram que nos posicionamentos excêntricos, as distorções das estruturas bucais e peribucais ocorreram na região média do ramo e dos processos condilares e coronóides, podendo simular hipertrofias ou atrofias ósseas. Também verificaram que nas radiografias obtidas com a mandíbula corretamente posicionada, os dentes apareceram alongados verticalmente e comprimidos no sentido horizontal. Os resultados estatísticos confirmaram discrepâncias horizontais da ordem de 5 a $25 \%$ e verticais de 15 a $20 \%$.

No ano de 1969, ZACH; LANGLAND; SIPPY ${ }^{97}$ reconhecendo a importância dos ortopantomógrafos na área odontológica, desenvolveram um cefalostato para avaliar sua eficiência em pesquisas longitudinais. Para o experimento, utilizaram 30 ortopantomografias de três tipos diferentes de grades metálicas com marcadores de chumbo simulando os arcos dentários e suas respectivas estruturas ósseas. Efetuaram uma série de medições lineares no sentido horizontal e vertical, em cada radiografia e compararam os resultados obtidos. Encontraram uma diferença considerável na ampliação da imagem entre os lados direito e esquerdo da radiografia devido 
às falhas inerentes ao desenho do aparelho. Citaram que as medidas no sentido horizontal não são confiáveis, mas podem ser consideradas suficientes para análise do desenvolvimento dentário, enquanto no sentido vertical os limites de erro nas medições são bastante aceitáveis. Os autores indicaram o uso destas radiografias nos estudos relacionados ao trajeto, à taxa e à seqüência de irrupção dentária, nos casos de extração seriada, na quantificação da perda de ancoragem, na avaliação de perdas prematuras de dentes decíduos, no planejamento e controle de cirurgias mandibulares e na verificação do desenvolvimento e irrupção dos terceiros molares. Acrescentaram também que ela pode ser usada na verificação das angulações dentárias e do paralelismo radicular, com bons resultados.

Ainda em 1969, RICHARDSON; LANGLAND; SIPPY78 divulgaram um aparelho semelhante ao de ZACH; LANGLAND; SIPPY ${ }^{97}$ para efetuar medidas lineares em radiografias seriadas de um mesmo paciente. Obtiveram como resultado um alto grau de exatidão no reposicionamento do paciente, com isso recomendando o uso desta radiografia em estudos longitudinais. 
Objetivando documentar a movimentação dentária ortodôntica por meio da radiografia panorâmica, HAUCK ${ }^{49}$ em 1970, propugnou um experimento com 10 pacientes apresentando extração dos primeiros pré-molares. A amostra constou também de radiografias obtidas em um aparelho da marca Panorex, no início do tratamento e por 10 meses consecutivos. Nas radiografias, realizaram-se sobreposições seriadas utilizando como referência a borda inferior da mandíbula e o plano palatino da maxila, com a sobreposição dos quadrantes em separado, tornando possível quantificar a retração dos caninos, a perda da ancoragem dos dentes posteriores e o grau de inclinação dentária. Diante dos resultados, o autor recomendou este método radiográfico para os estudos longitudinais do paralelismo radicular, do grau de reabsorção radicular e do padrão de irrupção dentária.

Ciente da importância da radiografia panorâmica e de sua correta interpretação ROWSE ${ }^{80}$, em 1971 procurou quantificar as distorções presentes nesta radiografia. Para isso, efetuou medições em diferentes tomadas de um crânio seco com alguns marcadores de chumbo, variando a posição no sentido vertical. As imagens obtidas apresentaram vários graus de ampliação, não existindo um fator de correção a ser aplicado. As 
porções mais nítidas destas radiografias localizaram-se na região dos molares inferiores. Na região anterior a interpretação é mais crítica, devido à sobreposição da coluna cervical. Outra região crítica, em função de sua posição no arco dentário e do funcionamento do aparelho é a dos pré-molares que apresenta ainda sobreposições dos dentes.

Neste mesmo ano, GARDINER; MILLS ${ }^{38}$ compararam as imagens obtidas por dois aparelhos de marcas comerciais distintas: Panorex e Ortopantomógrafo. Verificaram uma excelente visualização da região maxilomandibular em todos os casos, confirmando a grande utilidade das radiografias panorâmicas no tratamento ortodôntico e cirúrgico, e ainda apresentando valor didático para explicações aos pacientes. A dosagem de radiação, praticamente a mesma nos dois aparelhos, apresentou-se menor que a dosagem de uma série de 14 filmes periapicais.

Corroborando com as pesquisas de ROWSE ${ }^{80}$, a correta interpretação anatômica do ortopantomograma ganhou mais uma contribuição significativa em 1973, quando CHILES; GORES $^{27}$ relacionaram as sobreposições, as distorções e os artefatos que devem ser reconhecidos e considerados na 
interpretação desta radiografia. Afirmaram ainda que pode não existir uma boa definição de todas as estruturas, pois a forma da cabeça e dos arcos dentários influenciavam a imagem obtida, mesmo assim, os autores consideraram-na indispensável no diagnóstico clínico.

Com o firme propósito de verificar se as diferentes formas e tamanhos de arcos dentários poderiam ser radiografados precisamente nos aparelhos panorâmicos existentes no mercado, LUND; MANSON-HING63 em 1975, realizaram um estudo em 240 pacientes, divididos por sexo, raça e faixa etária. Os resultados mostraram que, obedecendo um correto posicionamento do paciente, todos os aparelhos pesquisados, Panorex, Panelipse e Ortopantomógrafo, radiografaram adequadamente os diferentes tipos de arcos dentários.

No mesmo ano, FREITAS ${ }^{35}$ propugnou um estudo com o objetivo de determinar, para jovens de 3 a 18 anos, as idades óssea, ponderal, estatural e dentária correlacionando os estimadores com a idade cronológica. A amostra constitui-se de 2130 jovens, de ambos os sexos, da região de Bauru-SP, que foram avaliados quanto ao peso e altura e examinados clinica e 
radiograficamente (radiografias panorâmicas, carpais e eventualmente periapicais). Concluiu-se que foi possível determinar as idades óssea, ponderal, estatural e dentária, bem como construir tabelas de evolução dentária para cada dente individualmente, considerando maxila e mandíbula e ambos os sexos. Observou-se ainda uma significância estatística para todas correlações calculadas, verificando estreita relação entre esses índices e a idade cronológica. O autor, porém, ressaltou que medições, proporções, idades ósseas e dentárias não fornecem, isoladamente, diagnóstico algum, devendo todos os parâmetros serem considerados em conjunto, juntamente com os aspectos clínicos.

Objetivando avaliar a exatidão das mensurações angulares nas radiografias panorâmicas utilizadas em ortodontia e cirurgia bucal, FRYKHOLM ${ }^{37}$ em 1977, desenvolveu uma pesquisa baseada em medições realizadas nas ortopantomografias de um objeto-teste, simulando condições clínicas diversas. Comprovou que a imagem produzida por este aparelho mostrou-se confiável para as avaliações angulares de estruturas posicionadas obliquamente, como os dentes, e que estas mensurações devem ser baseadas em detalhes anatômicos não muito distantes entre si. Para medidas angulares com 
propósitos clínicos, o autor aceitou uma variação de mais ou menos cinco graus, não sendo necessário o uso de fator de correção nestes casos.

Considerando a grande importância do ângulo goníaco no diagnóstico das alterações esqueléticas e no estudo do crescimento facial, no ano de 1977, MATILLA; ALTONEN; HAAVIKKO ${ }^{64}$ encetaram um estudo com a finalidade de comparar os valores deste ângulo em telerradiografias e radiografias panorâmicas. Para tanto, obtiveram radiografias ortopantomográficas de um crânio seco posicionado de diferentes maneiras no cefalostato e comparam os valores obtidos com as medições no próprio crânio e na telerradiografia. Depois, numa amostra de radiografias ortopantomográficas e telerradiografias pertencentes à 601 pacientes com idades entre 5 e 20 anos, compararam as imagens obtidas por essas duas técnicas. Concluíram que o valor do ângulo goníaco pode ser determinado nas ortopantomografias com a mesma exatidão que nas telerradiografias, com a grande vantagem que na ortopantomografia não há sobreposição destas estruturas. 
Em vista da grande popularidade da radiografia panorâmica e de seu emprego pelos ortodontistas na avaliação do paralelismo radicular, PHILLIP; HURST ${ }^{73}$ em 1978, pesquisaram as distorções existentes na imagem produzida por um aparelho Panorex em função das diferentes inclinações do plano oclusal. Projetou-se um dispositivo simulando um arco dentário, com vários fios ortodônticos no sentido vertical representando os dentes, soldados perpendicularmente a um fio de maior calibre, simulando o plano oclusal. Realizaram as tomadas radiográficas com diferentes inclinações do dispositivo, medindo os ângulos entre os fios verticais e o horizontal observando que o menor grau de distorção correspondia à imagem obtida quando o plano oclusal do objeto era inclinado 6 graus acima do plano horizontal. Dessa forma, os autores concluíram que a quantidade de distorção variava de acordo com a inclinação do plano oclusal, e que alterações de até 5 graus não apresentavam significado clínico na determinação do relacionamento aproximado dos longos eixos dos dentes.

Com o intuito de utilizar as radiografias panorâmicas para avaliações quantitativas das bases ósseas maxilar e mandibular em estudos de crescimento e desenvolvimento, em 1979, ALPERN ${ }^{5}$ idealizou um cefalostato para um aparelho da 
marca Panelipse. Para o experimento utilizou crânios humanos com marcadores metálicos para testar sua fidelidade. Concluiu que estas radiografias apresentam-se úteis para os diversos estudos em crânios com harmonia dentoesquelética e que embora as imagens apresentem ampliação tanto no sentido vertical como horizontal, essas distorções são aceitáveis e previsíveis.

Em 1982, MAYORAL ${ }^{65}$ utilizou radiografias panorâmicas como meio de diagnóstico para avaliar o paralelismo radicular e o grau de reabsorção dos dentes adjacentes aos espaços das extrações ao final do tratamento ortodôntico. A amostra constou de ortopantomografias obtidas no início, no final do tratamento e um ano após a remoção da contenção de 53 casos tratados ortodonticamente com a extração dos primeiros pré-molares e a partir destas, foram traçados os longos eixos dos caninos e segundos pré-molares. $\mathrm{O}$ autor considerou uma variação entre -5 e +5 graus: bom paralelismo; de +6 a +10 graus: aceitável; acima de +11 graus: deficiente; e abaixo de -6 graus: sobretratamento. Desta forma encontrou 70 \% dos casos com paralelismo bom ou aceitável, sem que os espaços voltassem a abrir e os outros $30 \%$ da amostra apresentaram problemas de reabertura de espaços ou 
uma aproximação demasiada das raízes. Sendo assim, o autor sugeriu outras investigações utilizando estas radiografias com o intuito de verificar o relacionamento final dos caninos e prémolares.

Preocupados com a impacção dos primeiros molares superiores contra a face distal dos segundos molares decíduos, BJERKLIN; KUROL ${ }^{14}$, em 1983, procuraram estudar a etiologia deste problema por meio de radiografias ortopantomográficas. Para avaliar as inclinações axiais destes dentes na radiografia, utilizaram como referência uma linha horizontal que passava pelos pontos mais inferiores das imagens das órbitas. Constataram que os dentes que atingem o plano oclusal sem problemas, apresentam uma inclinação axial para mesial, durante o trajeto de sua irrupção, menor do que os dentes impactados.

Neste mesmo ano, MLYNARSKA-ZDUANIAR ${ }^{68}$ avaliou as inclinações axiais dos longos eixos dos dentes permanentes irrompidos ou não em um aparelho da marca Panelipse. A amostra constituiu-se de radiografias panorâmicas pertencentes à 21 crianças, entre 7 e 8 anos de idade, com oclusão "normal". Para efetuar as medições dos dentes superiores e inferiores, 
utilizou como referência um plano oclusal tocando as pontas das cúspides mais proeminentes dos primeiros molares permanentes superiores e inferiores respectivamente para cada arco dentário. Determinou os ângulos formados entre os longos eixos dos dentes anteriores aos segundos molares permanentes para este estágio de desenvolvimento oclusal, estabelecendo médias e desvios padrão.

A grande preocupação de $\operatorname{ALPERN}^{6}$ residia em diminuir a exposição do paciente aos procedimentos de diagnóstico radiográfico em ortodontia. Em 1984, o autor discorreu sobre a indiscutível validade das radiografias panorâmicas e, nesta oportunidade, defendeu o correto posicionamento do paciente no aparelho obtendo desta forma, uma imagem com boa qualidade evitando repetições. Este cuidado especial proporciona radiografias com qualidade e exatidão adequadas para mensurar as alterações decorrentes dos tratamentos ortodôntico ou cirúrgico, e do crescimento nos estudos longitudinais.

Ainda em 1984, buscando investigar a validade das radiografias panorâmicas para medições angulares, SAMAWI; BURKE $^{82}$ utilizaram uma tela metálica na forma e medidas de 
um arco dentário normal de um jovem na dentadura permanente, para testar as distorções na imagem produzida por um aparelho ortopantomográfico fabricado pela Siemens. Os autores empregaram marcadores de chumbo posicionados paralelamente entre si para simular os dentes e usaram também, para servirem como referência nas medições, algumas estruturas anatômicas maxilares e mandibulares. Várias exposições com diferentes posicionamentos do objeto-teste no sentido horizontal e vertical foram obtidas, considerando a variação na postura dos pacientes. Concluíram que o grau de inclinação da cabeça do paciente está associado a uma certa quantidade de distorção angular, especialmente na área de prémolares e caninos. Os pesquisadores afirmaram ainda que mesmo nestas regiões mais críticas, as discrepâncias de 4 ou 5 graus entre dois dentes adjacentes ou entre duas exposições consecutivas de um mesmo dente, não representa uma contraindicação da radiografia panorâmica. Consideraram também, que a variação da distorção linear não é acompanhada pela distorção angular, pois em algumas regiões, principalmente nas partes laterais e inferior do ortopantomograma, estas medidas podem ser executadas com grande confiabilidade. 
Inter essados em comparar o grau de reprodução das medições lineares horizontais, verticais e das angulares na região da mandíbula, por meio de exposições seriadas de pacientes e crânios secos, com intervalos de tempo variados, LARHEIM; SVANAES ${ }^{59}$ em 1986, realizaram um estudo com o aparelho panorâmico Siemens 5. Verificaram que as medições lineares no sentido horizontal, devido à variação da distorção apresentada, não mostrava precisão adequada, por outro lado, a interpretação de medições angulares e lineares no sentido vertical mostrou-se viável, desde que as radiografias fossem obtidas por um mesmo operador. Afirmaram ainda que a determinação do ângulo goníaco é bastante exata neste método radiográfico.

Preocupados com a qualidade da imagem das radiografias panorâmicas, em 1987, BREZDEN; BROOKS ${ }^{18}$ avaliaram 500 radiografias para determinar os erros presentes nelas. A avaliação mostrou 15 tipos diferentes de erros técnicos e de processamento nestas radiografias, sendo que apenas uma delas não apresentava erro de posicionamento do paciente ou de processamento. A qualidade radiográfica para o diagnóstico foi julgada adequada em 365 radiografias, inadequada em 91 e sofrível em 44 outras. Os autores afirmaram que a qualidade de 
uma radiografia é de vital importância para o correto diagnóstico clínico e que os erros e artifícios de técnicas, embora muito comuns e freqüentes, podem comprometer o tratamento odontológico.

O interesse pela etiologia, prevalência e interpretação das impacções dos segundos molares inferiores, incentivou EVANS $^{34}$, em 1988, a pesquisar tais fatores em radiografias ortopantomográficas. Para o estudo, utilizou modelos de gesso e radiografias de 50 pacientes que apresentavam os segundos molares inferiores impactados, e mais 100 radiografias de pacientes com estes dentes irrompidos. Após a comparação entre as amostras, a autora concluiu que a quantidade de apinhamento apresentava-se menor no segundo grupo, bem como o ângulo formado entre os longos eixos dos primeiros e segundos molares. Para a interceptação desta ocorrência na dentadura mista precoce recomendou-se a extração dentária, para minimizar os apinhamentos e melhorar as condições de irrupção dos segundos molares inferiores.

Cientes da importância das radiografias panorâmicas no transcorrer de um tratamento ortodôntico, ALMEIDA; VASCONCELOS; INSABRALDE ${ }^{1}$ em 1988, indicaram-na no intuito 
de controlar e diagnosticar as alterações que possam ocorrer neste período, como por exemplo o desenvolvimento de dentes supranumerários, principalmente se for levado em consideração que estes podem aparecer em períodos tardios de desenvolvimento. Os autores acrescentaram ainda que as radiografias panorâmicas complementam o exame clínico com grande eficiência, refletem maior economia de tempo, quando comparadas às radiografias periapicais e propiciam menor exposição dos pacientes à radiação ionizante.

Mantendo o interesse em pesquisas sobre as avaliações angulares em radiografias ortopantomográficas, TAVANO et al. ${ }^{88}$ em 1989 , estabeleceram as linhas de referência para os arcos superior e inferior, no intuito de realizar avaliações angulares nessas radiografias. A princípio foram escolhidas 5 linhas, para posteriormente selecionar aquela que apresentasse maior facilidade de visualização radiográfica, menor alteração com o crescimento ou tratamento ortodôntico e proximidade com as estruturas dentoalveolares. Utilizaram três aparelhos diferentes para obtenção das radiografias e sobre elas foram traçados os reparos anatômicos e as linhas estudadas. Os autores selecionaram para medições das estruturas superiores, uma linha passando pelos pontos mais 
inferiores das órbitas, e outra linha interceptando os pontos mais centrais dos forames mentonianos para as mensurações das estruturas inferiores da radiografia.

Objetivando estabelecer um padrão para as inclinações dentárias axiais mesiodistais utilizando radiografias panorâmicas, URSI ${ }^{90}$ em 1989 empreendeu um complexo e interessante estudo. A amostra constituiu-se de 42 jovens brasileiros leucodermas de origem mediterrânea, com idades entre 12 e 17 anos, apresentando oclusão "normal". O autor comparou os valores obtidos em quatro diferentes ortopantomógrafos e verificou que pode-se utilizar o ortopantomógrafo, de fabricação nacional, da marca Funk como referência para uso clínico, apesar dos valores encontrados para os diversos aparelhos apresentarem diferenças estatisticamente significantes. Concluiu ainda que foi possível determinar um padrão médio normal para as inclinações axiais mesiodistais de todos o dentes irrompidos e que este padrão visa estabelecer bases quantitativas para a avaliação das inclinações axiais dentárias durante e após o tratamento ortodôntico, auxiliando na obtenção de resultados estáveis e com boa função oclusal. 
Realizando um estudo, em 1989, com radiografias ortopantomográficas de crianças entre 3 e 11 anos, para determinar a posição do forame da mandíbula nos sentidos horizontal e vertical, MINARELLI; RAMALHO ${ }^{66}$ tendo como base os traçados e medidas sobre as radiografias, concluíram que o forame se localiza no final do terço médio do ramo da mandíbula independente da faixa etária examinada e abaixo do plano oclusal, cuja distância diminui com o evolver da idade.

Em 1991, CAPELLI et al. ${ }^{21}$, compilando os dados literários comparou a radiografia panorâmica com o conjunto periapical completo, procurando verificar qual delas atende às necessidades básicas do Cirurgião-dentista, permitindo maior facilidade de se complementar o diagnóstico, de forma mais prática e com menor custo. Verificaram que a radiografia panorâmica apresenta menor dose de radiação ao paciente, menor custo e menor tempo operacional, indicando-a para inspeção mais ampla da região bucomaxilofacial, nas avaliações de patologias, nas intervenções cirúrgicas, no planejamento protético, para diagnóstico e acompanhamento em ortodontia e odontopediatria e em avaliações epidemiológicas. Por ser uma tomada extrabucal, indicaram-na também nos casos de trismo, imobilização e auxiliando naqueles pacientes rebeldes, que 
relutam em aceitar o tratamento. O levantamento periapical mostrou-se superior na detecção das lesões periapicais, cáries interproximais e alterações periodontais, estando indicado sempre que houver necessidade de maior detalhamento, já que a panorâmica oferece uma visão geral, com imagens desprovidas de detalhes.

Procurando determinar a acuidade da mensuração do ângulo goníaco em telerradiografia e ortopantomografia, neste mesmo ano, ALMEIDA et al. ${ }^{2}$ compararam os valores encontrados em medições diretas em 17 crânios secos com as imagens obtidas nestas duas técnicas radiográficas. Verificaram que as ortopantomografias apresentaram uma ligeira superioridade em relação às telerradiografias, devido à ausência de distorções significantes nesta região da radiografia e a facilidade de visualização de todo o contorno mandibular. Concluíram, com base na metodologia aplicada e nos resultados obtidos, que as radiografias panorâmicas constituem o método de escolha para esta mensuração.

A comparação das alterações angulares dos terceiros molares em pacientes tratados ortodonticamente com e sem extrações foi, em 1992, objeto de estudo de STAGGERS; 
GERMANE; FORSTON ${ }^{85}$. Utilizaram, para tanto, radiografias panorâmicas pré e pós tratamento de 78 pacientes, sendo 45 tratados sem extrações e 33 com extrações dos quatro primeiros pré-molares. Posteriormente, traçaram o longo eixo do terceiro molar e o plano oclusal e realizaram as mensurações angulares. Os resultados demonstraram que não houve diferenças estatisticamente significantes nas angulações dos terceiros molares, antes e após o tratamento, quando comparados os dois grupos. Assim, concluíram que o tratamento ortodôntico com e sem extração dos pré-molares pode melhorar a posição angular intra-óssea dos terceiros molares sem contudo, garantir que o mesmo irromperá com bom posicionamento.

Com o propósito de estudar a prevalência dos dentes supranumerários na região anterior e a relação desta anomalia com a dentição, o sexo, a localização e a morfologia, GUIMARÃES et al. ${ }^{47}$, em 1992, avaliaram radiografias panorâmicas e periapicais anteriores de pacientes na faixa etária entre 4 e 12 anos. Verificaram a presença de dentes supranumerários em $1,81 \%$ das radiografias examinadas sendo mais freqüente no sexo masculino e na segunda dentição. Os autores salientaram ainda que o diagnóstico precoce desta 
anomalia proporciona a realização de um tratamento preventivo, com a intervenção do odontopediatra e do ortodontista, visando o desenvolvimento normal da dentição.

Em 1993, CAVALCANTI et al. ${ }^{26}$ selecionaram uma amostra de 60 indivíduos, sendo 30 descendentes de japoneses e 30 leucodermas, na faixa etária de 20 a 30 anos, para estudar, por meio de elipsopantomografias e telerradiografias frontais, as grandezas lineares maxilomandibulares. Os autores concluíram, em relação às técnicas radiográficas, que as grandezas lineares estudadas apresentaram valores maiores nas elipsopantomografias, tanto nos descendentes de japoneses como nos leucodermas. Constataram também que a imagem radiográfica na telerradiografia frontal nos descendentes de japoneses apresentou-se maior que nos leucodermas.

Com o intuito de aprimorar conhecimentos e fornecer melhores subsídios aos exames complementares em odontologia e medicina e às perícias médico-odontológicas, CARVALHO et al. ${ }^{25}$, em 1994, propuseram-se a estudar e a comparar as ampliações dos segmentos ósseos crâniofaciais em traçados obtidos em radiografias panorâmicas por ambos os princípios ortopantomográfico e elipsopantomográfico. Os autores 
afirmaram que existem diferenças estatísticas significantes entre os dois sistemas. Os resultados mostraram que as radiografias panorâmicas apresentam diferentes graus de ampliação nas diversas dimensões lineares (horizontal e vertical), mas em relação às dimensões angulares, como o ângulo mandibular, observou-se uma reprodução fiel das mensurações craniométricas nos dois sistemas pantomográficos.

Em 1995, ALMEIDA; BÓSCOLO; HAITER NETO analisaram 1.315 radiografias panorâmicas com intenção de quantificar os erros encontrados nelas, alertando para a correção desses erros e para possíveis falhas que possam ocorrer no diagnóstico radiográfico decorrentes desses erros. Os erros foram distribuídos em seis categorias. Após analisá-los separadamente e em conjunto, concluíram que os erros relacionados ao posicionamento do paciente constituíram os mais comuns, dentre eles o alinhamento inadequado do plano sagital mediano do paciente, seguido do mal posicionamento da coluna vertebral deste; a escolha errada dos fatores de exposição corresponderam ao segundo maior número de erros; a negligência no processamento radiográfico foi responsável pela alteração no padrão de diagnóstico das radiografias constituindo o terceiro fator relacionado aos erros e finalmente, 
o erro que menos contribuiu para o resultado radiográfico final foi o posicionamento do chassi.

Todo método radiográfico apresenta um certo grau de distorção que sofre variações decorrentes dos procedimentos técnicos. A radiografia panorâmica utiliza o princípio tomográfico, no qual apenas a porção do objeto que se situa no plano de corte (exposição) do aparelho aparecerá na radiografia com nitidez. Desta forma o procedimento técnico para a obtenção da radiografia panorâmica apresenta-se bastante crítico. Cientes da importância da radiografia panorâmica para procedimentos que envolvem mensurações, como a ortodontia, ALMEIDA; BÓSCOLO; MONTEBELO FILHO4, em 1995, empreenderam um estudo com o objetivo de verificar e comparar as distorções presentes nas elipsopantomografias e nas ortopantomografias. A amostra constituiu-se de 50 modelos de gesso onde foram confeccionados dois tipos de arcos, utilizando fios de cobre de tamanhos conhecidos, o de maior diâmetro foi posicionado na face oclusal dos dentes, possibilitando medir a distorção horizontal e o de menor diâmetro, a distorção vertical. Após a perfeita adaptação dos arcos às arcadas dentárias, foram obtidas as radiografias panorâmicas com os pacientes corretamente posicionados nos 
aparelhos de raios X das marcas Funk e Siemens. Os resultados mostraram que em ambos os aparelhos a distorção apresentouse significante estatisticamente, em relação à medida real, sendo que o aparelho Funk apresentou distorção sempre menor que o Siemens e que as distorções foram maiores nos segmentos posteriores.

Por considerar o diagnóstico das disfunções crâniomandibulares uma tarefa muito complexa, TANAKA ${ }^{87}$, em 1996, realizou um trabalho procurando relacionar os dados da anamnese e do exame clínico àqueles obtidos dos exames radiográficos transcranianos e das tomografias computadorizadas em pacientes com sintomas de disfunção crânio-mandibular. A amostra constituiu-se de 40 pacientes de ambos os sexos, com idades entre 12 e 56 anos. Os pacientes relataram seus sintomas por meio de anamnese e no exame clínico foram observados os sinais de disfunção ou os fatores contribuintes. Todos os pacientes submeteram-se a tomadas radiográficas panorâmicas, transcranianas e tomografias computadorizadas a partir de cortes axiais. Verificou-se uma significante concordância entre os dados fornecidos pela radiografia transcraniana e a tomografia computadorizada, reforçando a validade do método transcraniano na investigação 
de problemas intra-articulares. A autora ressaltou ainda que o somatório de todas as informações proporciona maior embasamento e segurança ao diagnóstico definitivo.

Na busca de uma alternativa para o tratamento ortodôntico, JAGER; KABARITY; SINGELMANN ${ }^{54}$, em 1997, estudaram os efeitos da extração precoce dos segundos molares decíduos. Avaliaram 52 pacientes, por meio de análise cefalométrica computadorizada e de radiografias panorâmicas, obtidas no início e no final do tratamento. Ao término do tratamento, os terceiros molares tinham irrompido em apenas três pacientes. Não obstante, em média, observar-se um movimento para mesial dos terceiros molares, ocorreu também uma melhora significante na inclinação axial destes dentes, especialmente no arco superior.

Com o intuito de verificar a eficiência de diferentes técnicas radiográficas de uso odontológico, para identificação e localização do forame mentoniano e posteriormente determinar qual destas técnicas forneceria valores mensuráveis mais próximos do real, PINTO ${ }^{76}$, em 1998, realizou um estudo utilizando 31 mandíbulas e uma hemi-mandíbula, perfazendo um total de 63 regiões de pré-molares. Foram realizadas 
medidas da distância do forame mentoniano ao rebordo alveolar em radiografias periapicais, obtidas pelas técnicas do paralelismo, do paralelismo com tela milimetrada e na panorâmica. Procurando estabelecer qual técnica seria mais adequada para o planejamento cirúrgico de implantes dentários, concluiu que não houve diferença estatisticamente significante que justificasse uma preferência por qualquer das técnicas utilizadas quando o objetivo fosse apenas a visualização do forame mentoniano. Entretanto, em relação às mensurações, as radiografias periapicais do paralelismo e paralelismo com tela milimetrada apresentaram valores mais fidedignos, enquanto as radiografias panorâmicas mostraram imagens ampliadas impossibilitando avaliações lineares com precisão.

No mesmo ano, AMIR et al. ${ }^{8}$ avaliaram a precisão das medidas lineares e angulares realizadas em radiografias panorâmicas. A amostra constituiu de 25 mandíbulas dissecadas com marcadores metálicos que foram radiografadas em um aparelho panorâmico. Realizaram medições lineares e angulares diretamente na peça dissecada e posteriormente nas imagens radiográficas e compararam os valores obtidos. Os autores verificaram que as mensurações angulares na radiografia apresentaram valores bastante próximos dos reais. Salientaram 
ainda que, embora tenham observado distorções nas medições lineares, a utilização da radiografia panorâmica para essas mensurações nos sentidos vertical, horizontal e oblíquo apresenta-se válida se estas forem realizadas apenas no mesmo lado da mandíbula.

Interessados em avaliar a qualidade das radiografias panorâmicas nos consultórios odontológicos, RUSHTON; HORNER; WORTHINGTON ${ }^{81}$, em 1999, examinaram 1813 radiografias coletadas de 41 clínicas particulares. Os pesquisadores avaliaram as imagens e atribuíram uma classificação de acordo com a qualidade de cada radiografia. Os resultados mostraram que apenas $0,8 \%$ das radiografias apresentaram excelente qualidade na classificação, enquanto $66,2 \%$ foram consideradas aceitáveis para diagnóstico e 33\% inaceitáveis. Para melhorar a qualidade das radiografias panorâmicas os autores atentaram para os fatores técnicos durante a tomada radiográfica, principalmente em relação ao posicionamento do paciente e para o processamento dos filmes.

Recentemente, BRUKS et al. ${ }^{19}$ (1999) encetaram uma pesquisa para avaliar a necessidade e a importância dos exames radiográficos para o diagnóstico e plano de tratamento 
ortodôntico. Os resultados enfatizaram a importância de uma seleção criteriosa e individual de radiografias para documentação ortodôntica, uma vez que o ortodontista deve requisitar apenas as radiografias que julgar indispensável para o diagnóstico e planejamento de cada caso individualmente prevenindo exposições desnecessárias às radiações ionizantes. A radiografia panorâmica, segundo esta investigação, foi o exame radiográfico mais freqüentemente requisitado, enquanto a telerradiografia apresentou importância secundária para o planejamento dos casos. 


\section{2- INCLINAÇÃO AXIAL MESIODISTAL}

\section{CONSIDERAÇÕES SOBRE OS ASPECTOS ANATÔMICOS, OCLUSAIS E ORTODÔNTICOS}

Desde 1949, DEWEL ${ }^{31}$ demonstrava preocupação em relação aos dentes apresentarem uma inclinação de seus longos eixos para mesial, variando de acordo com sua função, sendo que qualquer desvio do normal, se apresenta, principalmente, com um aumento de sua inclinação. De acordo com o referido autor, o contato proximal entre os dentes é proporcionado por esta inclinação mesial específica, não somente na época da irrupção, mas também nos anos vindouros, quando os dentes sofrem desgastes pela própria função na cavidade bucal, mas permanecem unidos pelo componente anterior de forças, que seria ativado pela pressão funcional de oclusão dos dentes antagonistas inclinados na mesma direção.

Sabendo da importância do correto posicionamento mesiodistal dos longos eixos dentários para a manutenção da estabilidade dos resultados obtidos pelo tratamento ortodôntico, HOLDAWAY50, em 1952, sugeriu a incorporação de angulações nos braquetes substituindo as dobras de segunda ordem nos fios de nivelamento. Segundo o autor, os braquetes 
devem ser angulados para compensar a folga do fio ortodôntico dentro de suas canaletas nos dentes submetidos a maiores movimentações. Este artifício também pode ser empregado no preparo de ancoragem e na substituição das dobras artísticas, resultando numa inclinação mais divergente dos longos eixos dentários, e proporcionando uma anatomia mais natural, principalmente no segmento ântero-superior do arco dentário. O autor alertou ainda que muitos casos eram concluídos sem a obtenção do paralelismo radicular. Nos locais das extrações, as raízes dos dentes adjacentes apresentavam uma configuração em "V", sendo este um dos fatores predisponentes à reabertura de espaço.

Neste mesmo ano, BEYRON ${ }^{13}$ aconselhou que a direção das forças oclusais deveria ser distribuída pelo maior número de dentes, estando o mais próximo possível dos longos eixos dos mesmos.

Ainda em 1952, buscando relacionar fatores que contribuíssem para a estabilidade dos tratamentos ortodônticos e tentando minimizar as recidivas, $S T R A N G^{86}$ relacionou o estabelecimento do posicionamento axial normal de cada dente, ou de forma propositadamente modificada, como uma tentativa 
de sobrecorreção, criando condições de uma melhor resistência às forças que tendem a provocar recidiva da má oclusão, indicando que o procedimento ortodôntico corretivo deve levar em consideração o relacionamento final das coroas e raízes dentárias.

Em 1963, DEMPSTER et al. ${ }^{30}$ desenvolveram uma pesquisa que daria início aos estudos mais complexos sobre a anatomia dentária. Estudando quantitativa e qualitativamente o arranjo das raízes dentárias em 11 crânios secos com dentaduras completas, os autores objetivaram determinar as inclinações axiais mesiodistais e vestibulolinguais desta amostra provinda da Índia e com padrões oclusais satisfatórios. Os dentes foram extraídos dos crânios, hemi-seccionados e reinseridos nos respectivos alvéolos. Com o auxílio de uma broca longa obteve-se canais, que receberam fios ortodônticos para evidenciar os trajetos dos mesmos por meio de telerradiografias em norma lateral e frontal, e de fotografias em tamanho natural dos espécimes preparados. Desta forma, tornou-se possível a quantificação das inclinações radiculares em relação à anatomia craniana estabelecendo médias e desviospadrão para todos os dentes. 
Um ano mais tarde, YOUNG ${ }^{96}$ observou que cada dente encontra-se posicionado conforme o tipo de esforço requisitado, sendo que as suas distintas inclinações correspondem a um modelo perfeito de estabilidade sob função. A inclinação para distal de seus ápices possibilita a oclusão de dois dentes antagonistas numa posição bastante vantajosa, permitindo que a força oclusal seja transmitida paralelamente às suas raízes. Quando isto não ocorre, observa-se danos aos tecidos de sustentação e aos dentes.

Segundo WHELLER ${ }^{94}$ (1965), normalmente os dentes apresentam suas coroas inclinadas para mesial em graus variáveis e embora diferentes crânios apresentem discrepâncias quanto aos valores absolutos, geralmente observa-se uma tendência a essa inclinação mesial. O autor afirmou que cada dente apresenta a inclinação que melhor resiste às forças mastigatórias e se algum dente encontrar-se mal posicionado, sua eficiência funcional torna-se prejudicada, assim como, sua estabilidade. Esta disposição espacial específica garante a manutenção dos pontos de contato proximais dentários e a correta dissipação das forças funcionais. 
Compulsando a literatura pertinente à estabilidade dos casos ortodonticamente tratados, GRABER ${ }^{44}$, em 1966, constatou que a reabertura de espaços nos locais das extrações era conseqüência do paralelismo radicular inadequado.

O argumento de WHELLER ${ }^{94}$ corroborou com as opiniões de SICHER; DuBRUL ${ }^{84}$ que em 1970, afirmaram que as distintas posições dos dentes no osso alveolar coincidem com a direção das forças mastigatórias resultantes neste ponto, sendo que esta obliqüidade axial reflete a direção das forças exercidas pelos músculos elevadores da mandíbula.

Do estudo de GARINO ${ }^{39}$, em 1971, concluiu-se que os dentes superiores apresentam seus ápices inclinados para distal obedecendo a um padrão de inclinação axial mesiodistal normal que aumenta progressivamente dos incisivos até os pré-molares. O primeiro molar entretanto, encontra-se verticalizado, enquanto os outros molares apresentam uma inclinação mesial dos seus ápices. No arco inferior, os incisivos estão verticalizados e a partir do canino ocorre um aumento gradativo das inclinações dos ápices para distal. 
Com o intuito de prevenir a recidiva em casos tratados ortodonticamente com extração, EDWARDS ${ }^{32}$, em 1971, analisou 20 sítios de extração (10 pacientes com duas extrações). O autor sugeriu uma cirurgia periodontal para eliminar a dobra gengival provocada pela movimentação ortodôntica reduzindo, desta forma, o número de recidivas de reabertura de espaços. O paralelismo radicular e o contato justo dos dentes aproximados também constituem outro fator de estabilidade dos casos tratados com extração.

ANDREWS $^{10}$ ao apresentar o grande clássico da ortodontia “As seis chaves para a oclusão normal"em 1972, incluiu as inclinações axiais mesiodistais como uma das "chaves" para a obtenção de uma oclusão "normal". O autor coletou uma amostra de 120 modelos com oclusão normal e sem tratamento ortodôntico, onde observou que as porções gengivais dos longos eixos das coroas dentárias, encontravam-se inclinadas para distal em graus variáveis, mas de maneira previsível. Nos dentes ântero-superiores, esta inclinação é crítica, devido às alturas oclusogengivais de suas coroas, já que o seu grau de inclinação determina a quantidade de espaço ocupado no arco dentário, com implicação na oclusão dos dentes posteriores, além de sua importância estética para o paciente. 
Neste mesmo ano, ROCKE ${ }^{79}$, sugeriu que os casos tratados ortodonticamente com extrações fossem avaliados com radiografias periapicais para verificação do paralelismo radicular entre os dentes que seriam aproximados, antes mesmo do procedimento cirúrgico (exodontia). O autor salientou ainda que uma convergência dos ápices dos caninos e pré-molares seria necessária para obtenção de uma maior estabilidade do caso, em relação à manutenção do fechamento do espaço.

Segundo os estudos de GLICKMAN ${ }^{41}$, de 1974, as forças oclusais decompõem-se em diversas direções em função dos planos inclinados dos dentes e tendem a movimentá-los para mesial devido um componente resultante de força anterior. Esta força seria transmitida dos dentes posteriores para os anteriores por meio dos pontos de contato proximais. Na linha média, entretanto, ocorreria uma neutralização pela força homóloga proveniente do outro hemi-arco.

Relacionando os objetivos do tratamento ortodôntico às funções desempenhadas pelo aparelho edgewise, RENFROE ${ }^{77}$, em 1975 preconizou a colocação dos acessórios paralelamente às faces oclusais e incisais dos dentes, obtendo assim, uma inclinação apropriada dos dentes em relação ao plano oclusal. 
Salientou ainda que na dentadura permanente as coroas dentárias apresentam uma inclinação mesial proporcionando boa estética e função oclusal adequada e sendo assim, quando os braquetes encontram-se corretamente posicionados nos dentes inclinados, os longos eixos dos acessórios e dos dentes não coincidem.

Objetivando avaliar uma oclusão estática que correspondesse às necessidades funcionais, em 1976, ANDREWS $^{11}$ novamente correlacionou os vários aspectos das suas "chaves para a oclusão normal" à função desenvolvida. Relacionou a correta inclinação mesiodistal das coroas dos dentes anteriores à obtenção de pontos de contato satisfatórios e ao preenchimento de espaço no arco dentário, posicionando corretamente os dentes posteriores, com pontos de contatos proximais cerrados, contribuindo também com a estética desta região. O autor preconizou diferentes graus de inclinação para os dentes superiores. Para os incisivos centrais e laterais, recomendou angulações de $5^{0}$ e $9^{0}$ respectivamente, proporcionando pontos de contatos adequados, estética e função satisfatória além de permitir um correto posicionamento dos dentes no arco dentário. Os caninos superiores apresentariam inclinação de $11^{\circ}$, de maneira, que durante os 
movimentos de lateralidade, estes contatassem com apenas seus homólogos inferiores. Se os caninos superiores apresentarem-se muito verticalizados poderiam interferir, em alguns movimentos excursivos, com os primeiros pré-molares inferiores e permitiriam uma desoclusão posterior prematura comprometendo a oclusão anterior mutuamente protegida. Porém a desoclusão posterior, durante o movimento protrusivo, pode tornar-se prejudicada se os caninos superiores estiverem excessivamente inclinados para mesial. No caso dos pré-molares, para que suas cúspides vestibulares deslizem sem toque entre as cúspides dos dentes antagonistas nos movimentos de lateralidade, devem apresentar uma posição relativamente vertical. Já os molares superiores, necessitam de uma inclinação distal de seu longo eixo $\left(5^{0}\right)$ para proporcionar um contato adequado com seus antagonistas.

Neste mesmo ano, interessado na avaliação do paralelismo radicular dos dentes aproximados para fechar 0 espaço, HATASAKA ${ }^{48}$ encetou um estudo com radiografias periapicais e interproximais de 28 pacientes tratados ortodonticamente com extração de primeiros pré-molares. O autor observou quatro possíveis situações de relacionamento radicular ao final do tratamento: raízes paralelas sem espaço 
entre as coroas, raízes divergentes, raízes convergentes sem toque dos ápices e raízes convergentes e ápices tocando. Uma nova avaliação nestes mesmos locais num total de 110 quadrantes foi efetivada depois de um período de contenção e pós-contenção variando de 1 a 13 anos. O autor concluiu que os melhores resultados, em termos de paralelismo radicular e manutenção do fechamento do espaço ao Iongo do tempo, incluíam os casos que apresentaram, ao término do tratamento, raízes paralelas com uma inclinação axial adequada e com quantidades proporcionais de osso de suporte.

Dois anos mais tarde, estudando espécimes dissecados, BERKOVITZ; HOLLAND; MOXHAM ${ }^{12}$ constataram a tendência ao paralelismo radicular e à inclinação dos ápices para distal corroborando com os estudos anteriores. E ainda afirmaram que as forças mastigatórias incidiam sobre as superfícies oclusais dos dentes com uma resultante no sentido mesial, podendo este fator estar relacionado às inclinações axiais dos dentes.

Estudando casos de discrepâncias de tamanho dentário positiva na região ântero-superior, TUVERSON ${ }^{89}$, em 1980, ressaltou a possibilidade, por meio do aumento da 
inclinação mesiodistal dos longos eixos dos caninos e incisivos, de se ocupar mais espaço no arco dentário. O autor afirmou que, com esta conduta torna-se possível o fechamento de espaços em até 2 milímetros sem, contudo, provocar transtornos funcionais e estéticos ao paciente.

Ampliando as pesquisas sobre as forças oclusais e observando o periodonto de sustentação, em 1983, GOLDMAN; $\mathrm{COHEN}^{42}$, consideraram que a manutenção destas estruturas depende da axialidade dos esforços oclusais, pelo fato de que 2/3 das fibras do ligamento periodontal encontram-se direcionadas para suportar este tipo de pressão. O componente anterior participa da dissipação das forças oclusais, sendo conseqüência da correta distribuição destas.

Contribuindo significantemente para o aprimoramento das técnicas ortodônticas, em 1984, VIGORITO ${ }^{92}$, atentou os profissionais sobre os detalhes da montagem de um aparelho fixo da técnica edgewise. Em relação à colocação dos braquetes, o autor preconizou que estes deveriam posicionarem-se paralelamente às bordas incisais ou oclusais dos dentes, ou então, formando um ângulo em relação àquelas bordas. Nos dentes ântero-superiores e caninos 
inferiores, as angulações de $3^{\circ}$ para o incisivos centrais, $4^{\circ}$ para os laterais e $5^{\circ}$ para ambos os caninos, no sentido distocervical, permitiriam, ao final do tratamento, a obtenção das corretas inclinações axiais mesiodistais (posicionamento artístico). Nos primeiros molares inferiores, estas inclinações, quando empregadas, objetivariam um preparo de ancoragem. Para orientar a colagem angulada dos braquetes, o autor sugeriu a construção de anguladores de $3^{\circ}, 4^{\circ}$ e $5^{\circ}$ com o fio retangular.

Na tentativa de eliminar totalmente a contenção ortodôntica na região ântero-inferior, WILLIAMS ${ }^{95}$, em 1985 apresentou seu estudo longitudinal de 21 anos. Durante esse tempo, dedicou-se ao estudo da estabilidade pós-tratamento nesta região. Sugeriu que, ao término do tratamento, os incisivos inferiores apresentem os ápices mais inclinados para distal do que normalmente é observado, sendo os incisivos laterais mais que os incisivos centrais. Afirmou também que as coroas destes dentes tendem a apinhar quando as raízes encontram-se convergentes ou até mesmo paralelas.

O mecanismo de transmissão das forças axiais foi objeto de estudo de CAMPOS JR. ${ }^{20}$, em 1986. O autor inferiu que a distribuição destes esforços pode estar relacionada com a 
integridade dos pontos de contato proximais em uma oclusão cúspide-embrasura, característica dos objetivos do tratamento ortodôntico onde ocorre o relacionamento de um dente contra dois.

Corroborando com a opinião de VIGORITO ${ }^{92}$, em 1986, INTERLANDI ${ }^{52}$ recomendou que os braquetes dos incisivos superiores e caninos superiores e inferiores fossem angulados, na montagem do aparelho, para obtenção do posicionamento artístico eliminando, desta forma, a incorporação das dobras de segunda ordem nos segmentos anteriores dos arcos. Preconizou para os incisivos centrais superiores uma inclinação de $3^{\circ}$, para os laterais $4^{\circ}$ e para os caninos superiores e inferiores $6^{\circ}$ e $5^{\circ}$, respectivamente.

Com o intuito de avaliar a angulação mesiodistal dos dentes póstero-inferiores, em 1988, LUCCHESI; WOOD; NORTJÉ62 realizaram um trabalho utilizando um modelo com pinos metálicos encaixados na posição das raízes com angulações conhecidas. Dois tipos de radiografias foram obtidas: radiografias panorâmicas e pela técnica do filme plano. Os resultados indicaram que a técnica do filme plano foi mais precisa que a da radiografia panorâmica. Na finalização do 
tratamento ortodôntico é prática comum, antes da remoção do aparelho, avaliar as angulações mesiodistais das raízes nos segmentos posteriores dos arcos dentários, principalmente em casos com extração e subseqüente fechamento de espaço. Na revisão de literatura constataram que esta avaliação é feita freqüentemente por meio de radiografia panorâmica, que apresenta nível de radiação menor, maior facilidade na obtenção, porém se não é capaz de indicar com precisão as angulações radiculares e o paralelismo, seu uso em avaliação pós-tratamento ortodôntico poderia ser questionado. Os autores concluíram que a interpretação radiográfica é subjetiva e que a discordância entre uma e outra técnica é de importância limitada.

Interessado nas particularidades da oclusão dentária, PICOSSE $^{75}$, em 1990, também discorreu sobre essa característica oclusal, alegando que no arco superior, todos os dentes possuem seus longos eixos inclinados para distal, especialmente o primeiro molar, cuja cúspide distovestibular encontra-se num plano mais inferior que a mesiovestibular. No arco inferior, o autor observou os mesmos padrões de inclinação citados por GARINO ${ }^{39}$. Convém salientar que ambos os autores 
desconsideraram o desvio radicular distal, que pode apresentarse mais ou menos acentuado em alguns dentes.

Na tentativa de estabelecer bases quantitativas para a avaliação das inclinações axiais mesiodistais de todos os dentes permanentes durante e após o tratamento ortodôntico, URSI et al. ${ }^{91}$, em 1990, realizaram um estudo que determinou os padrões médios normais destas inclinações. Para os autores, um caso bem tratado ortodonticamente, deveria exibir radiograficamente, a mesma disposição radicular daquela presente na oclusão normal. No arco superior os incisivos centrais e laterais de cada quadrante devem encontrar-se ligeiramente convergentes. Os caninos mantêm uma discreta inclinação para a distal, assim como os demais dentes, com exceção dos segundos molares que devem se apresentar inclinados para a mesial. Os incisivos inferiores devem aparecer verticalizados e a partir dos caninos os dentes remanescentes aumentam gradativamente a inclinação de seus ápices para a distal.

Interessados em avaliar os resultados da reabilitação bucal em adultos, ENACAR; ALTAY; HAYDAR ${ }^{33}$ em 1992, afirmaram que a associação da ortodontia e da periodontia 
aumentam o êxito dos tratamentos nestes pacientes. A correção da inclinação axial dos dentes, por meio de aparelhos ortodônticos, pode prevenir uma exposição pulpar durante o preparo protético e também melhorar as condições periodontais do paciente.

Em 1994, CAPELOZZA FILHO; MACHADO ${ }^{22}$ introduziram um novo método para avaliação da inclinação axial mesiodistal do primeiro molar superior pela radiografia panorâmica. Utilizaram cinco radiografias ortopantomográficas de casos tratados sem extrações e sobre estas foram traçados os contornos inferiores das órbitas, o contorno externo da mandíbula e os contornos externos dos primeiros molares superiores. Em seguida, traçaram-se os longos eixos destes dentes de duas maneiras distintas: primeiro seguindo a direção da raiz palatina e depois a bifurcação das raízes vestibulares. Verificaram que o longo eixo do primeiro molar superior quando traçado sobre a radiografia panorâmica orientado pelo canal radicular da raiz palatina, muitas vezes apresentava-se deslocado para mesial. Assim, concluíram que a utilização da bifurcação das raízes vestibulares apresentou-se mais estável e fiel, indicando valores de inclinação próximos a $90^{\circ}$ que corroboram com os achados clínicos, devendo ser adotada como 
rotina na determinação do posicionamento do primeiro molar superior.

Com o propósito de avaliar e comparar as inclinações axiais mesiodistais dos dentes ao final do tratamento ortodôntico, em casos tratados pelas técnicas edgewise e straigth wire, CAPELOZZA FILHO et al. ${ }^{23}$, ainda em 1994, empreenderam um estudo utilizando as radiografias panorâmicas de casos tratados sem extração. A amostra constituiu-se de 52 ortopantomografias sendo 26 do grupo 1 (edgewise) e 26 pertencente ao grupo 2 (straight wire). Os braquetes adotados na técnica de Andrews (straight wire) apresentavam angulações para os dentes superiores de $5^{0}$ para os incisivos centrais, $9^{0}$ para os laterais, $11^{0}$ para os caninos, $2^{0}$ para os pré-molares e $5^{0}$ para os primeiros molares. Na técnica edgewise, a colagem incluiu angulação dos incisivos centrais superiores de $5^{0}$, incisivos laterais superiores de $3^{0}$, angulação um pouco mais acentuada dos caninos superiores variando entre $5^{0}$ e $7^{0}$ e tubos dos primeiros molares superiores com inclinação de $3^{0}$. Da avaliação das radiografias panorâmicas verificaram uma única diferença consistente entre as duas técnicas de tratamento: maior inclinação axial mesiodistal dos caninos superiores na técnica straight wire. As demais 
diferenças foram clinicamente desprezíveis. Concluíram ainda, que a radiografia panorâmica, como parâmetro para detectar erros e introduzir correções no posicionamento radicular dos dentes antes do término do tratamento, pode ser adotada como método morfológico coadjuvante ao exame clínico.

No ano de 1995, $\mathrm{LEE}^{60}$ relatou que em um tratamento ortodôntico o movimento de raiz é essencial, não só para obter paralelismo entre as raízes, mas também alcançar inclinações axiais mesiodistais corretas, principalmente nos segmentos anteriores.

Recentemente, CAPELOZZA et al. ${ }^{24}$ (1999) verificaram a necessidade da individualização dos braquetes totalmente programados com a finalidade de se obter uma oclusão individualizada de acordo com o tipo de má oclusão e característica facial do paciente, diminuindo desta forma, o número de dobras de qualquer ordem a serem realizadas nos arcos. Esta individualização pressupõe colocar nos braquetes dos dentes envolvidos na movimentação, características capazes de responder às exigências da mecânica adotada, preservando imediatamente ao final do movimento as características de posicionamento consideradas ideais. Para se obter as corretas 
inclinações axiais mesiodistais dos dentes, os autores sugeriram que os braquetes apresentassem angulações um pouco diferentes daquelas preconizadas para a técnica edgewise e também distintas das prescrições originais introduzidas por Andrews. Assim, recomendaram para cada tipo de má oclusão (Classe I, II e III), braquetes individualizados em relação às angulações para os arcos superiores e inferiores como seguem: para más oclusões de Classe I angulações de $5^{\circ}$ para os incisivos centrais e $9^{\circ}$ para os laterais superiores e de $2^{\circ}$ para os incisivos inferiores, para os caninos superiores e inferiores $8^{\circ}$ e $5^{\circ}$ respectivamente, pré-molares superiores com $0^{\circ}$ e inferiores $2^{\circ} \mathrm{e}$ braquetes sem angulação $\left(0^{\circ}\right)$ para os molares superiores e inferiores; na más oclusões de Classe II angulações apenas para os caninos superiores $\left(5^{\circ}\right)$ e incisivos inferiores $\left(2^{\circ}\right)$ e para as más oclusões de Classe III braquetes superiores angulados em $5^{\circ}$ para os incisivos centrais, $9^{\circ}$ para os laterais e $11^{\circ}$ para os caninos. 


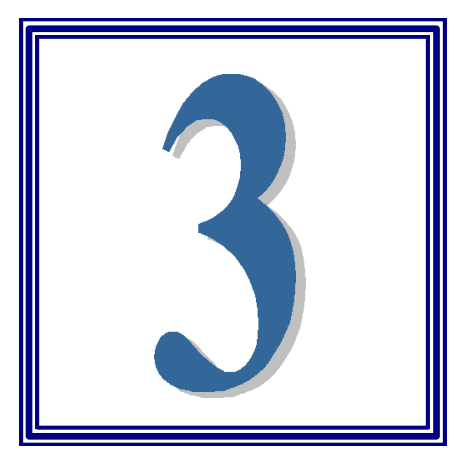

PROPOSIÇÃO 


\section{3 - PROPOSIÇÃO}

O propósito desta pesquisa consiste em:

Comparar os valores médios normais, das inclinações axiais dentárias, propostos por URSI ${ }^{90} \mathrm{com}$ :

* as inclinações axiais mesiodistais dos dentes ânterosuperiores e caninos inferiores ao início do tratamento ortodôntico; e

* estas inclinações ao término do tratamento ortodôntico; 


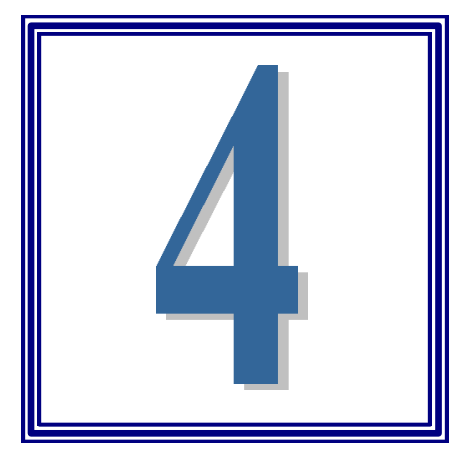

MATERIAL E MÉTODOS 


\section{4 - MATERIAL E MÉTODOS}

\section{1- Material}

\subsection{1 - Obtenção da amostra}

Para este estudo retrospectivo a amostra constou de 80 radiografias panorâmicas, de 40 jovens brasileiros de ambos os sexos, provenientes do acervo da clínica particular do Professor Dr. Renato Rodrigues de Almeida. O critério para seleção da amostra baseou-se nas seguintes características:

1-Todas as radiografias foram obtidas em um mesmo aparelho e por um único operador;

2-Os jovens apresentavam má oclusão de Classe I e II de Angle;

3-Todos os pacientes foram tratados ortodonticamente com a técnica edgewise simplificada sem extrações, por um único profissional;

4-Na montagem dos aparelhos todos os braquetes receberam angulações de $3^{0}$ para os incisivos superiores e de $5^{0}$ para os caninos superiores e inferiores; e

5-Exclusão de jovens apresentando agenesias ou dentes supranumerários. 


\subsection{2 - Material para a obtenção das radiografias}

Todas as radiografias foram obtidas em um mesmo aparelho e por um único operador. Os pacientes foram radiografados no mesmo local onde receberam o tratamento, em um aparelho Yoshida, modelo Panoura, com fatores de exposição até $90 \mathrm{kV}$ e $15 \mathrm{~mA}$, utilizando-se um chassi plástico Yoshida-Panoura equipado com um ecran intensificador de média intensidade de marca e modelo Toshiba E U 5A0335, contendo o filme radiográfico $15 \times 30 \mathrm{~cm}$ X-Omat da Kodak.

Os filmes foram processados sob luz de segurança adequada (filtro 6B da Kodak) pelo método manual de tempo e temperatura utilizando revelador e fixador Kodak, por um único operador, seguindo as recomendações de processamento da Disciplina de Radiologia da Faculdade de Odontologia de Bauru, da Universidade de São Paulo ${ }^{7}$, sendo posteriormente secados, em secadora própria para radiografias da marca E.B.M., e armazenados nas respectivas pastas de documentação.

Para garantir a proteção biológica dos pacientes em relação à radiação ionizante, utilizou-se avental de chumbo de $3 \mathrm{~mm}$ de espessura durante as tomadas radiográficas. 


\subsection{3 - Material para elaboração do traçado e mensuração dos ângulos}

Para elaborar o traçado e posteriormente efetuar a mensuração angular utilizou-se:

-negatoscópio;

-moldura de cartolina preta;

-papel Ultraphan 0,07mm;

-fita adesiva Mágica Scotch 810 da 3M;

-lapiseira com grafite 0,5mm;

-borracha branca macia;

-régua milimetrada Desetec, modelo 7120; e -transferidor Desetec número 8110.

\section{2- Métodos}

\subsection{1- Radiografias panorâmicas}

Utilizaram-se duas radiografias panorâmicas, de cada paciente, consideradas como T1 (inicial) e T2 (final). As radiografias foram obtidas com o paciente posicionado com 0 plano oclusal paralelo e o plano sagital mediano perpendicular, ambos em relação ao solo, estando os dentes desocluidos com o 
auxílio de um pedaço de espátula abaixadora de língua interposto na região anterior (figura 5 ).
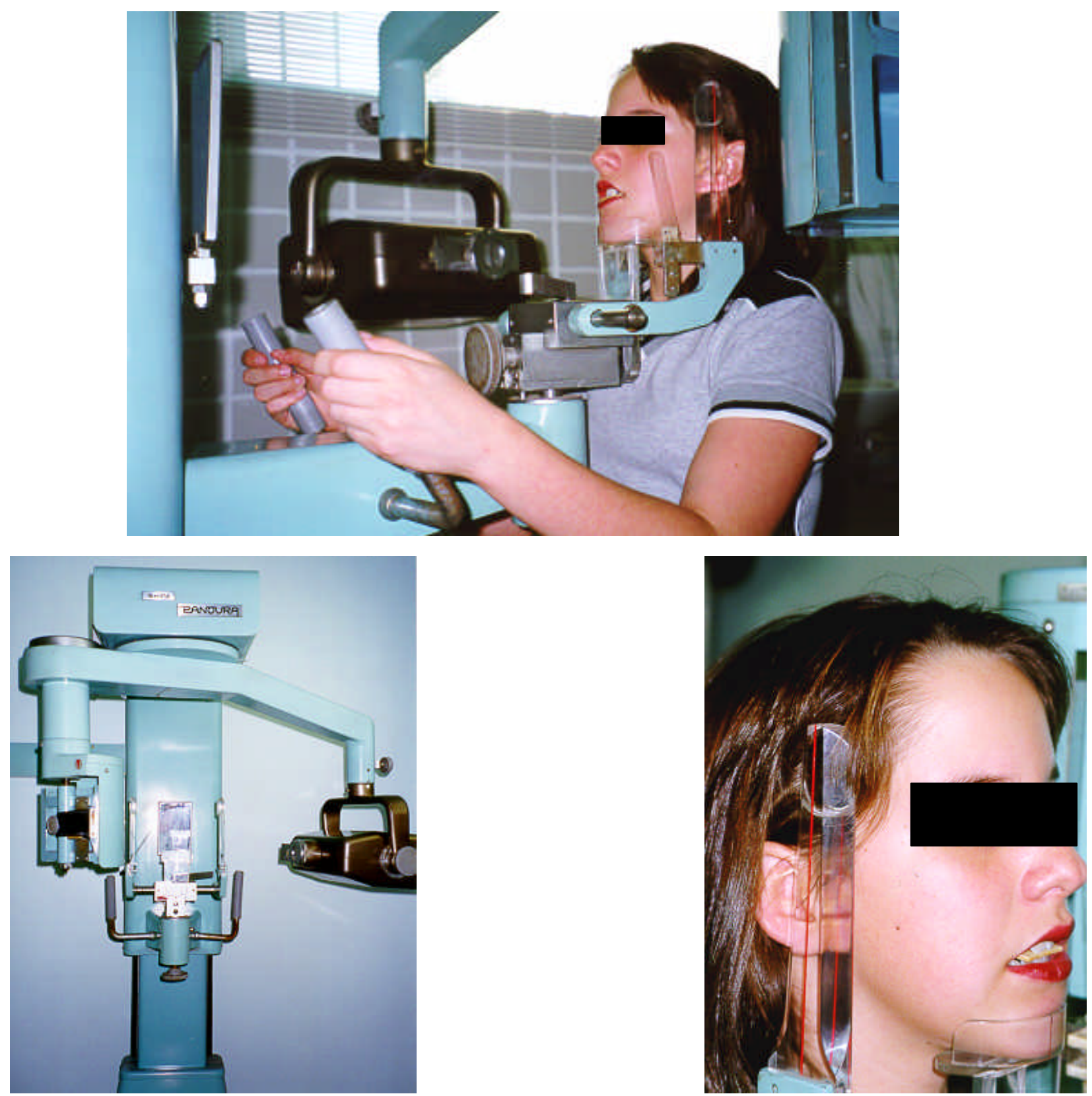

FIGURA 5- Aparelho radiográfico e correto posicionamento do paciente. 


\subsection{2- Elaboração do traçado}

Adaptou-se em cada película radiográfica uma folha de papel de acetato transparente "Ultraphan" de tamanho $14,5 \mathrm{~cm}$ de largura por $21,0 \mathrm{~cm}$ de comprimento e espessura de $0,07 \mathrm{~mm}$. Os traçados foram efetuados manualmente sobre o negatoscópio pelo pesquisador e conferido por outros dois profissionais, em uma sala obscurecida, emoldurados com cartolina preta, expondo-se as áreas correspondentes as estruturas anatômicas de interesse desta pesquisa.

\subsubsection{1- Delimitação das estruturas dentoesqueléticas}

O traçado constituiu-se dos seguintes reparos anatômicos (figura 6):

a)-limites inferiores das cavidades orbitárias;

b)-contorno externo da imagem da mandíbula;

c)-forames mentonianos;

d)-coroas e raízes dos incisivos centrais e laterais permanentes superiores; e

e)-coroas e raízes dos caninos permanentes superiores e inferiores. 
Material e Métodos

77

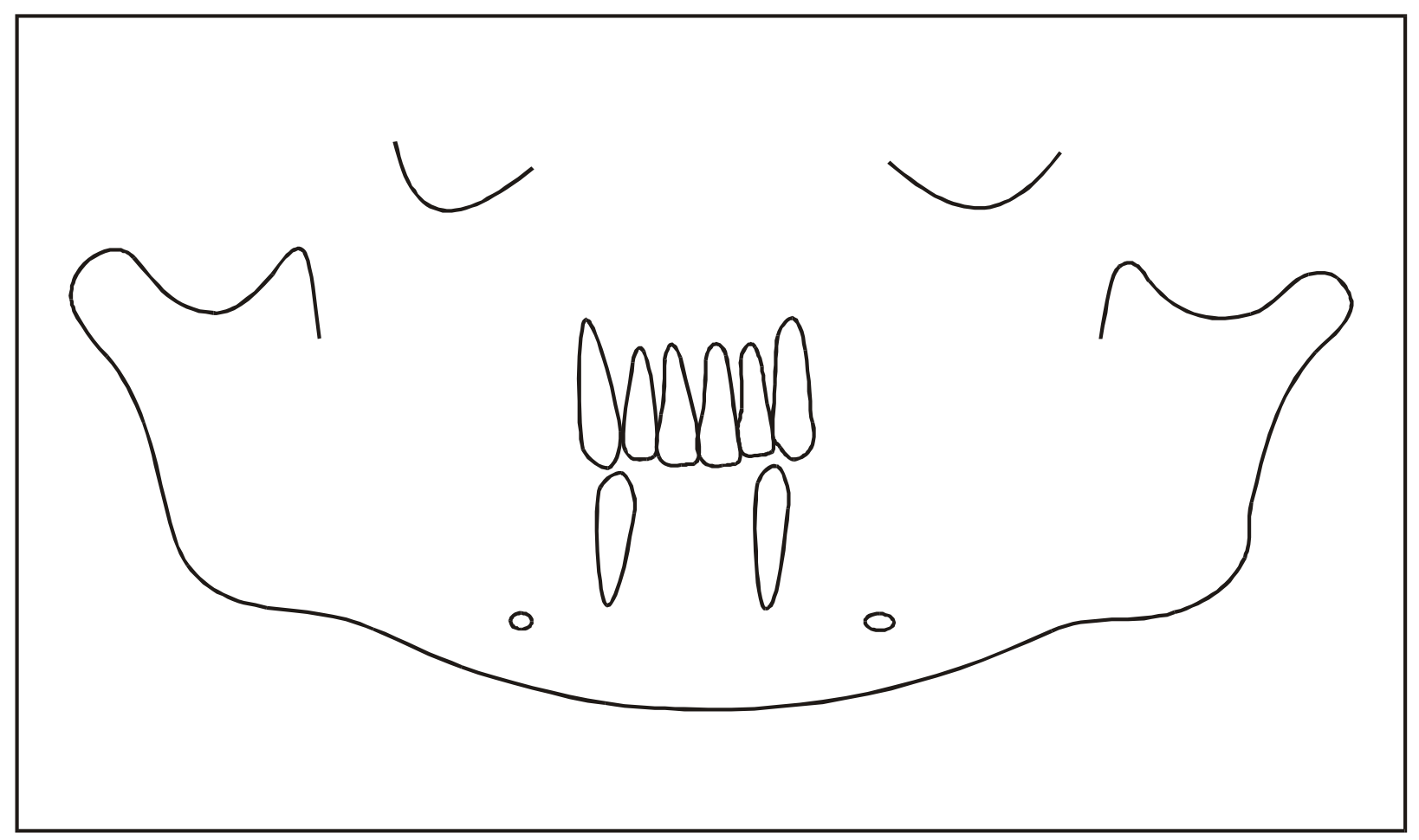

FIGURA 6- Desenho anatômico das estruturas dentoesqueléticas. 


\subsubsection{2.- Demarcação dos pontos de referência (figura 4).}

Empregaram-se os pontos de acordo com TAVANO et al. ${ }^{88}$ (figura 7 ):

-Or ${ }_{d}$ (orbital direito) ponto mais inferior da cavidade orbitária direita;

$-O r_{e}$ (orbital esquerdo) ponto mais inferior da cavidade or bitária esquerda;

$-\mathrm{FM}_{\mathrm{d}}$ (forame mentoniano direito) ponto mais central do forame mentoniano direito; e

$-\mathrm{FM}_{\mathrm{e}}$ (forame mentoniano esquerdo) ponto mais central do forame mentoniano esquerdo. 


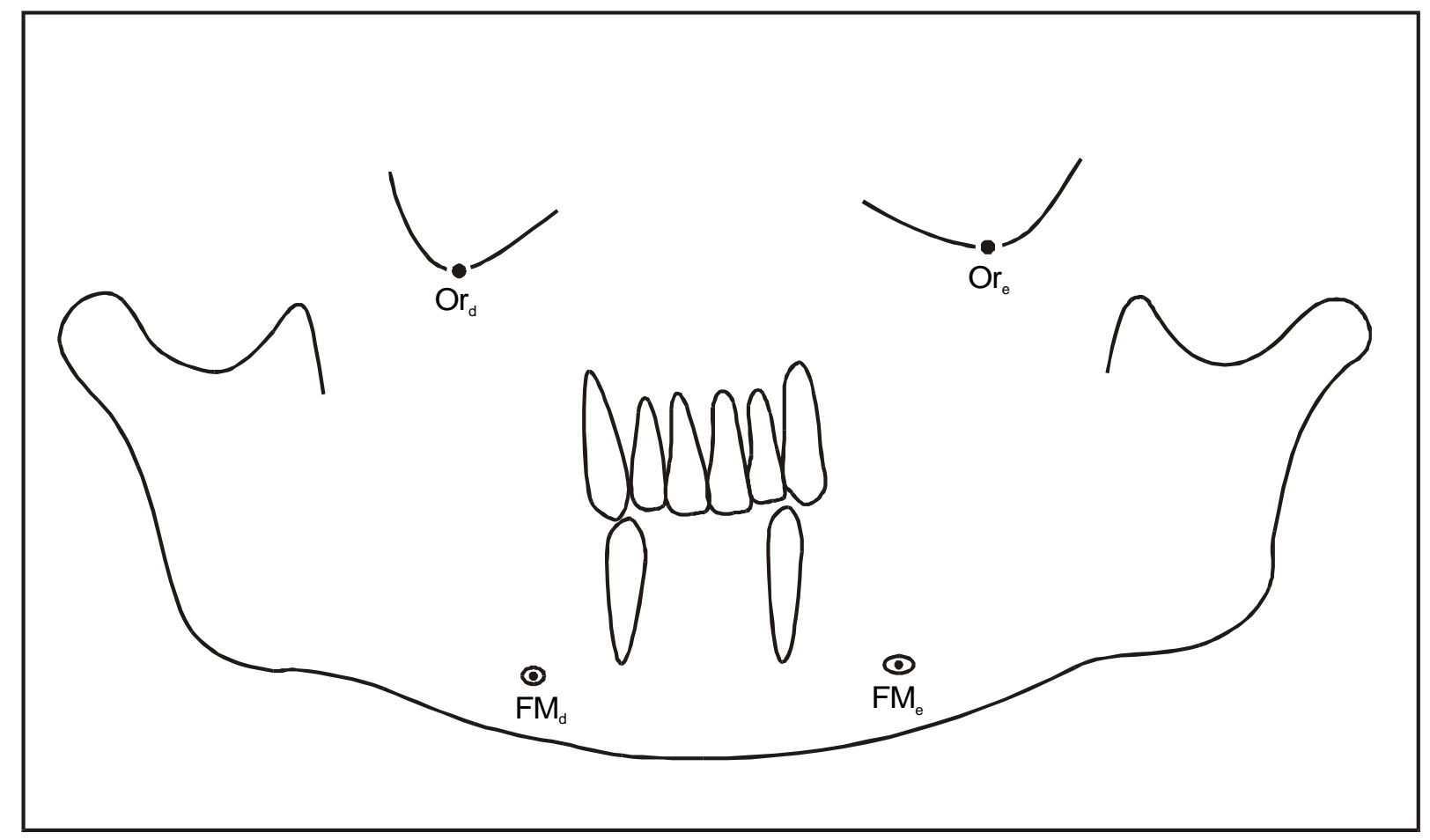

FIGURA 7 - Pontos de referência. 


\subsubsection{3- Linhas de referência.}

As linhas de referência utilizadas seguiram a indicação de um estudo anterior ${ }^{88}$.

\subsubsection{1-Horizontais (figura 8A).}

a) - Linha interorbitária (IO): linha que passa pelos pontos $\mathrm{Or}_{\mathrm{d}}$ e $\mathrm{Or}_{\mathrm{e}} \mathrm{e}$

b) - Linha intermentoniana (IM): linha que passa pelos pontos $\mathrm{FM}_{\mathrm{d}}$ e $\mathrm{FM}_{\mathrm{e}}$.

\subsubsection{2-Verticais (figura 8B).}

c) - Longos eixos dos dentes: determinados pela imagem do canal radicular em sua maior extensão. 


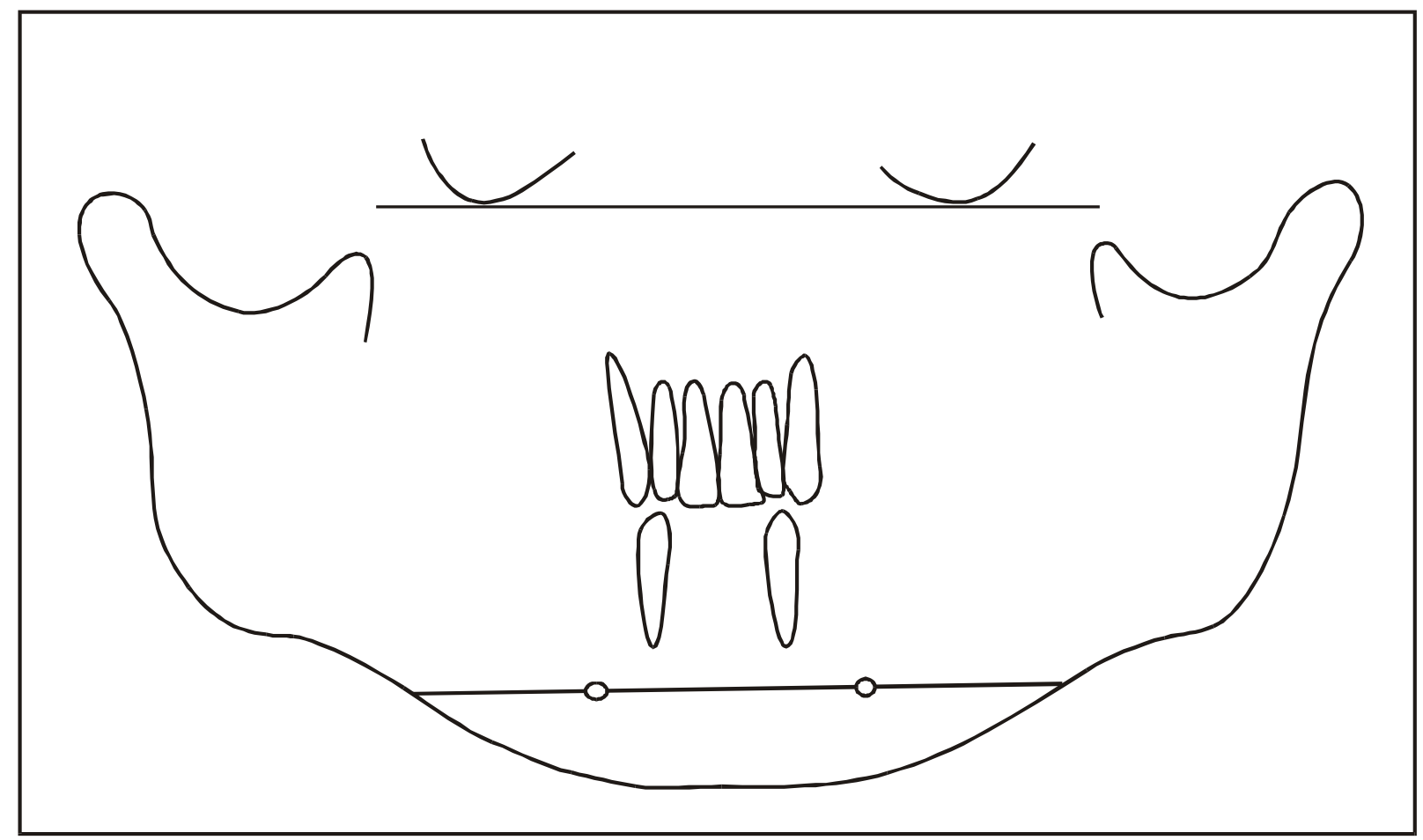

FIGURA 8A - Linhas de referência horizontais. 


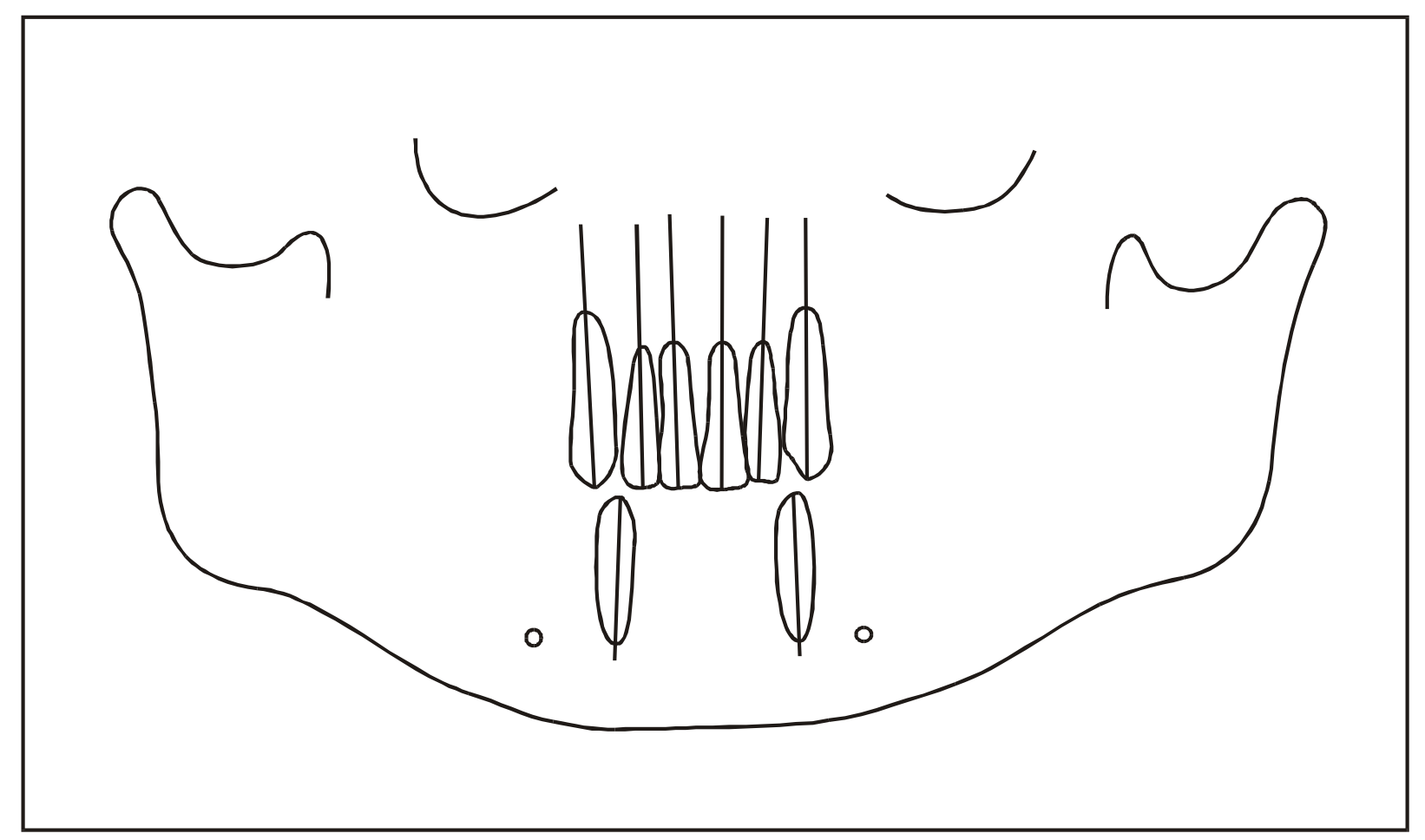

FIGURA 8B - Linhas de referência verticais. 


\subsubsection{4- Mensuração dos ângulos}

Demarcados os pontos e as linhas, procedeu-se à mensuração dos ângulos formados pelos longos eixos dos dentes e as linhas de referência utilizadas para o arco superior e inferior (figuras 9A e B).

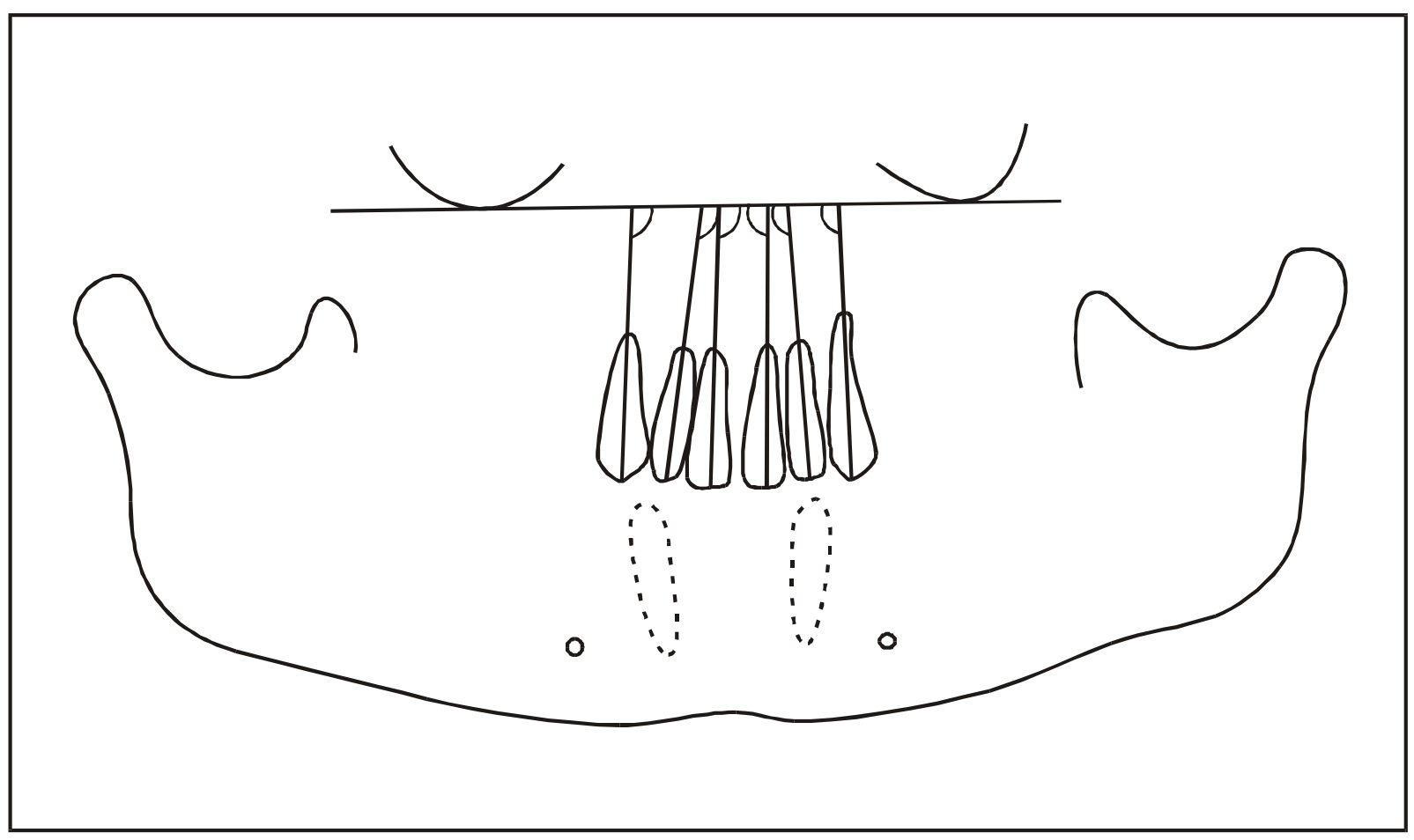

FIGURA 9A -Ângulos formados pelos longos eixos dos dentes superiores e a linha interorbitária. 


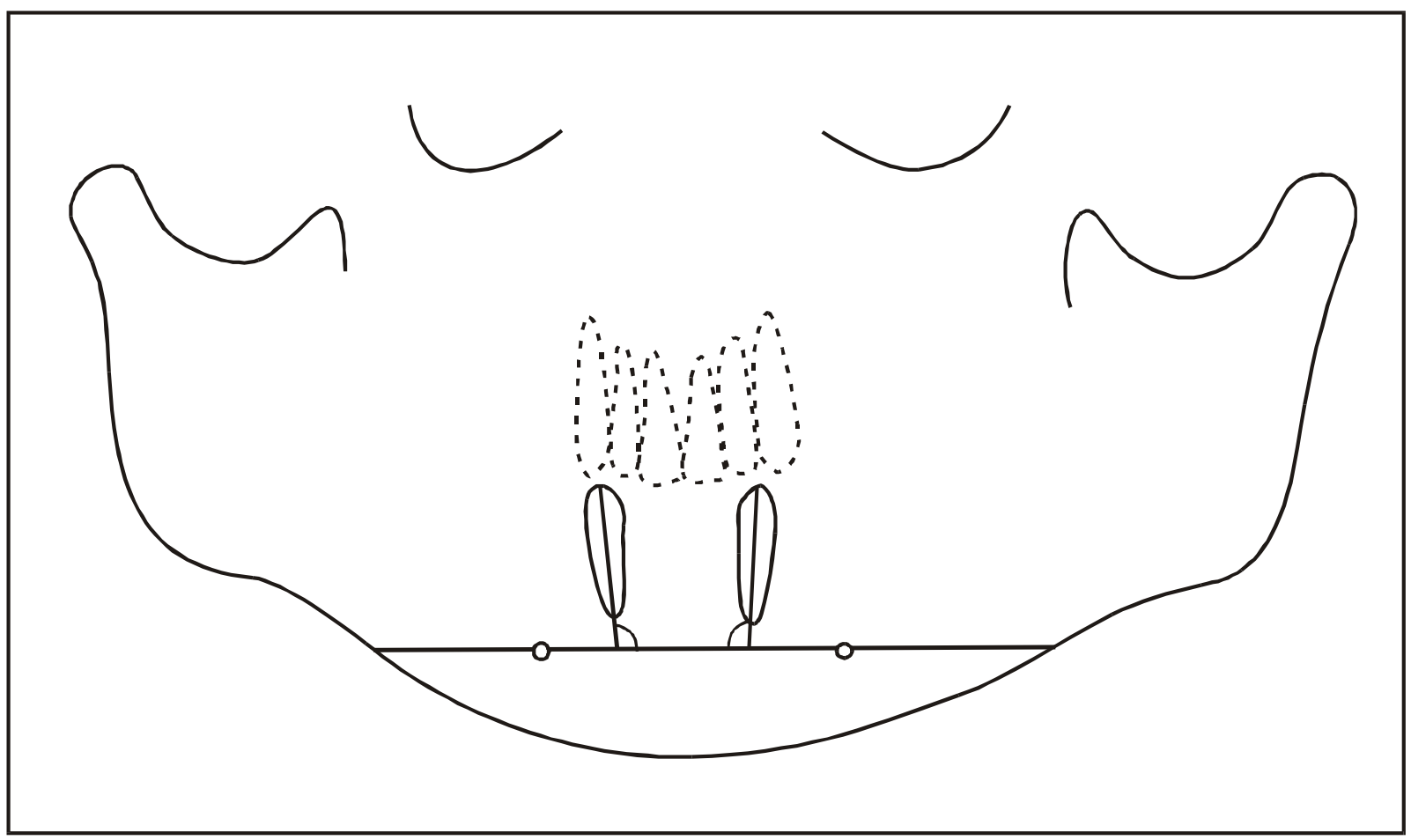

FIGURA 9B -Ângulos formados pelos longos eixos dos dentes inferiores e a linha intermentoniana. 


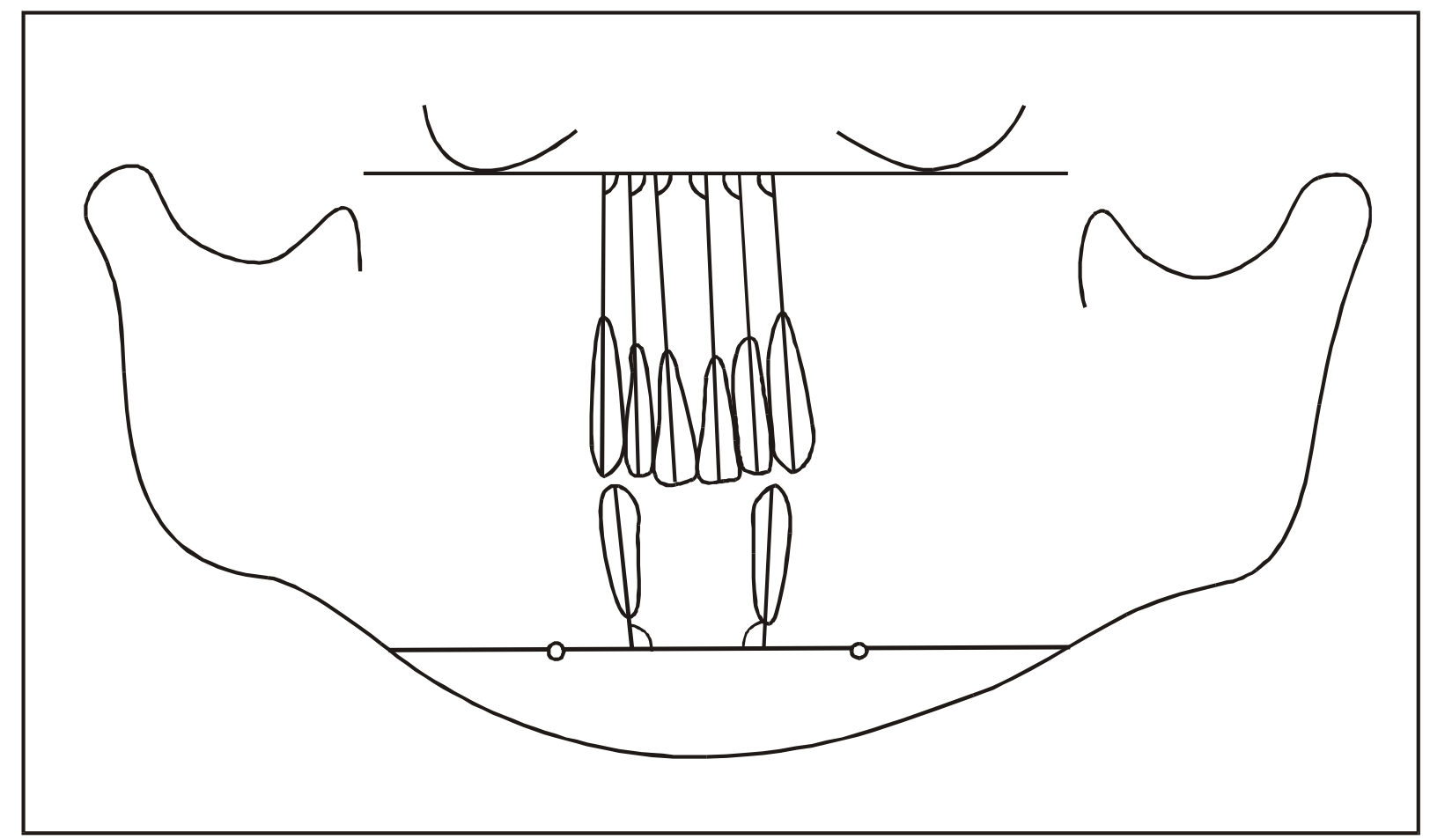

FIGURA 10 -Desenho anatômico com pontos, linhas e ângulos de interesse. 

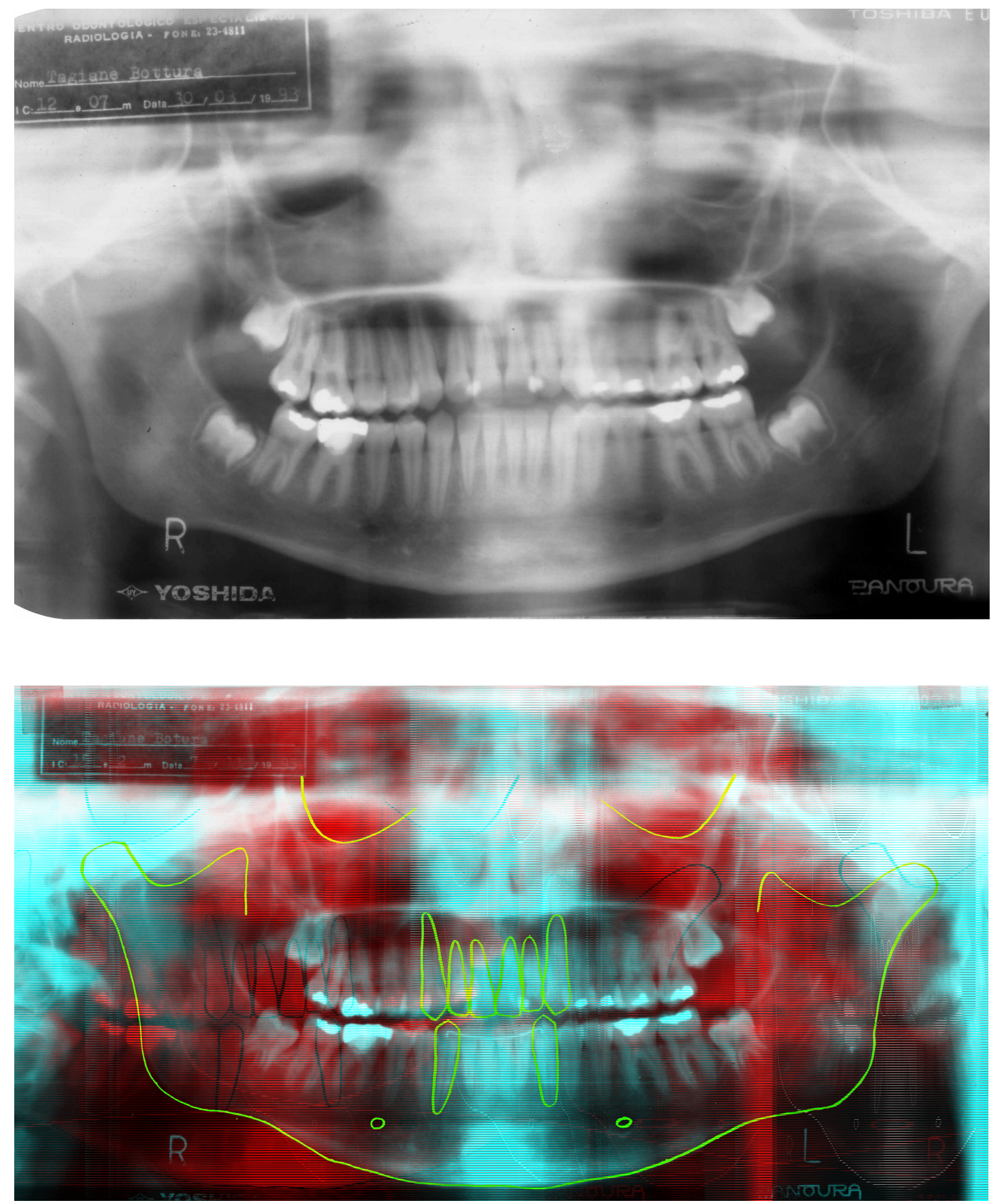

FIGURA 11 -Radiografia panorâmica inicial e final, com traçado, de um mesmo paciente da amostra. 


\section{3- Análise estatística}

A análise estatística objetivou a comparação de duas amostras aleatórias independentes. A hipótese a ser testada é a de igualdade entre as duas médias, contra a hipótese de diferença entre as médias. O tratamento estatístico foi desenvolvido pelo "software" Sigma Stat*, disponível na Biblioteca da Faculdade de Odontologia de Bauru, que infere os resultados paramétricos analisando os pré-requisitos do teste. Ele é meticuloso ao apresentar o nível de significância $(P)$ da probabilidade de erro tipo I, e do poder do teste $(1-\beta)$ da probabilidade de erro tipo II, em vez de apresentar somente as significâncias nos níveis $1 \%$ e $5 \%$. Sempre que os dados permitiram, pelo seu ajustamento à Normal e Igualdade de Variâncias, a indução foi realizada pelo teste t de Student. Quando isto não foi possível utilizou-se o teste de MannWhitney.

*Sigma Stat ${ }^{T M}$, statistical software for Windows Version 1.0. 


\section{4- Erro do método}

Verificou-se o erro metodológico selecionando, aleatoriamente, 10 radiografias panorâmicas iniciais (T1) e 10 finais (T2) que foram traçadas e medidas por duas vezes, em períodos diferentes. Desta repetição obteve-se o erro casual e o erro sistemático.

Determinou-se o erro casual pela fórmula de DAHLBERG ${ }^{29}$ :

$$
\mathrm{S}_{\mathrm{e}}^{2}=\frac{\sum \mathrm{d}^{2}}{2 \mathrm{n}}
$$

onde $\mathrm{S}_{\mathrm{e}}$ representa o erro de Dahlberg; $\Sigma \mathrm{d}^{2}$ corresponde ao somatório dos quadrados das diferenças entre as primeiras e as segundas medições e $2 \mathrm{n}$ representa o dobro do número de casos que as medidas foram repetidas. Para o erro sistemático utilizou-se o teste t de Student. 


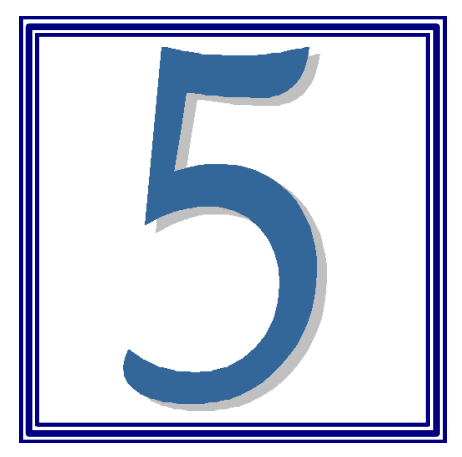

RESULTADOS 


\section{5 - RESULTADOS}

A apresentação dos resultados encontra-se organizada em tabelas. Previamente aos resultados específicos da pesquisa, as tabelas 1 e 2 demonstram o erro metodológico. As médias aritméticas, os desvios-padrão e a comparação entre as médias das inclinações axiais mesiodistais dos referidos dentes em T1 e T2 encontram-se nas tabelas 3, 4 e 5, respectivamente. Os valores das inclinações dentárias para cada paciente localizam-se nos anexos 1 e 2 .

Os resultados das comparações entre os valores obtidos em T1 e T2 com os valores médios normais obtidos por URSI $^{86}$ dispõem-se, respectivamente, nas tabelas 6, 7e 8. 
Tabela 1 - Média e desvio-padrão das diferenças, valor de t (erro sistemático), níveis de probabilidade de significância (P) e índice de Dahlberg (erro casual) dos valores obtidos da comparação entre as duas séries de traçados das radiografias panorâmicas iniciais ( $\mathrm{T} 1)$.

\begin{tabular}{c|c|c|c|c|c}
\hline DENTE & Média & $\begin{array}{c}\text { Desvio- } \\
\text { padrão }\end{array}$ & $\mathbf{T}$ & $\mathbf{P}$ & Dahlberg \\
\hline 43 & 0,2 & 0,9 & $-0,519$ & 0,6164 & 0,33 \\
\hline 33 & 0,4 & 0,8 & 1,56 & 0,1527 & 0,53 \\
\hline 23 & 0,5 & 1,4 & $-1,03$ & 0,3305 & 0,50 \\
\hline 22 & 0,4 & 1,9 & 0,596 & 0,5658 & 0,64 \\
\hline 21 & 0,1 & 0,1 & 0,318 & 0,7577 & 0,57 \\
\hline 11 & 0,6 & 0,9 & 2,03 & 0,0735 & 0,50 \\
\hline 12 & 0,2 & 1,3 & 0,367 & 0,7220 & 0,56 \\
\hline 13 & 0,6 & 1,2 & 1,65 & 0,1333 & 0,41 \\
\hline
\end{tabular}


Tabela 2 - Média e desvio-padrão das diferenças, valor de t (erro sistemático), níveis de probabilidade de significância (P) e índice de Dahlberg (erro casual) dos valores obtidos da comparação entre as duas séries de traçados das radiografias panorâmicas finais (T2).

\begin{tabular}{c|c|c|c|c|c}
\hline DENTE & Média & $\begin{array}{c}\text { Desvio- } \\
\text { padrão }\end{array}$ & $\mathbf{T}$ & $\mathbf{P}$ & Dahlberg \\
\hline 43 & 0,1 & 1,4 & 0,111 & 0,9140 & 0,60 \\
\hline 33 & 0,4 & 1,6 & $-0,692$ & 0,5064 & 0,59 \\
\hline 23 & 0,5 & 0,9 & $-1,68$ & 0,1278 & 0,45 \\
\hline 22 & 0,1 & 1,2 & $-0,264$ & 0,7976 & 0,49 \\
\hline 21 & 0,9 & 2,4 & $-1,25$ & 0,2417 & 0,42 \\
\hline 11 & 0,1 & 1,48 & 0,107 & 0,9173 & 0,57 \\
\hline 12 & 0,0 & 1,58 & 0,00 & 1,0000 & 0,38 \\
\hline 13 & 0,1 & 1,3 & $-0,122$ & 0,9059 & 0,69 \\
\hline
\end{tabular}


Tabela 3 - Média e desvio-padrão, em graus, das inclinações axiais mesiodistais dos dentes ântero-superiores e caninos inferiores, obtidos das radiografias panorâmicas ao início do tratamento ortodôntico (T1).

\begin{tabular}{c|c|c|c}
\hline DENTE & No $^{0}$ panorâmicas & MÉDIA & Desvio-padrão \\
\hline 43 & 40 & 88,9 & 6,5 \\
\hline 33 & 40 & 91,8 & 6,4 \\
\hline 23 & 40 & 89,4 & 5,5 \\
\hline 22 & 40 & 94,9 & 5,0 \\
\hline 21 & 40 & 88,2 & 3,5 \\
\hline 11 & 40 & 88,2 & 3,8 \\
\hline 12 & 40 & 93,4 & 6,0 \\
\hline 13 & 40 & 89,8 & 6,1 \\
\hline
\end{tabular}


Tabela 4 - Média e desvio-padrão, em graus, das inclinações axiais mesiodistais dos dentes ântero-superiores e caninos inferiores, obtidos das radiografias panorâmicas ao término do tratamento ortodôntico (T2).

\begin{tabular}{c|c|c|c}
\hline DENTE & No panorâmicas & MÉDIA & Desvio-padrão \\
\hline 43 & 40 & 82,1 & 6,0 \\
\hline 33 & 40 & 81,9 & 6,8 \\
\hline 23 & 40 & 85,8 & 4,3 \\
\hline 22 & 40 & 88,1 & 4,8 \\
\hline 21 & 40 & 85,7 & 3,4 \\
\hline 11 & 40 & 87,2 & 3,2 \\
\hline 12 & 40 & 91,1 & 5,1 \\
\hline 13 & 40 & 87,3 & 4,9 \\
\hline
\end{tabular}


Tabela 5 - Média e desvio-padrão das diferenças, graus de liberdade, valor de t e níveis de probabilidade de significância (P) dos valores obtidos das radiografias panorâmicas ao início (T1) e ao término do tratamento ortodôntico (T2).

\begin{tabular}{c|c|c|c|c|c}
\hline DENTE & Média & $\begin{array}{c}\text { Desvio- } \\
\text { padrão }\end{array}$ & $\begin{array}{c}\text { Graus de } \\
\text { liberdade }\end{array}$ & $\mathbf{T}$ & $\mathbf{P}$ \\
\hline 43 & 6,7 & 7,8 & 39 & 5,47 & $<0,0001^{* *}$ \\
\hline 33 & 9,9 & 8,9 & 39 & 7,05 & $<0,0001^{* *}$ \\
\hline 23 & 3,6 & 6,4 & 39 & 3,55 & $0,0010^{* *}$ \\
\hline 22 & 6,7 & 6,1 & 39 & 7,02 & $<0,0001^{* *}$ \\
\hline 21 & 2,5 & 4,3 & 39 & 3,67 & $0,0007^{* *}$ \\
\hline 11 & 1,2 & 4,6 & 39 & 1,63 & 0,1112 \\
\hline 12 & 2,3 & 5,9 & 39 & 2,49 & $0,0172^{*}$ \\
\hline 13 & 2,5 & 8,1 & 39 & 1,98 & $0,0546^{*}$ \\
\hline
\end{tabular}

Diferenças estatisticamente significantes:

$\mathrm{P}<0,05^{*}$

$\mathrm{P}<0,01 * *$ 
Tabela 6 -Valores médios normais (padrão) das inclinações axiais mesiodistais de cada dente individualmente, médias dos valores obtidos ao início do tratamento ortodôntico (T1) e níveis de probabilidade de significância (P).

\begin{tabular}{c|c|c|c}
\hline DENTE & Média Padrão & Média T1 & P \\
\hline 43 & 88,0 & 89,0 & 0,5071 \\
\hline 33 & 87,0 & 92,0 & $<0,0001^{* *}$ \\
\hline 23 & 87,0 & 89,5 & $0,0087^{* *}$ \\
\hline 22 & 90,5 & 95,0 & $<0,0001^{* *}$ \\
\hline 21 & 86,5 & 88,0 & $0,0446^{*}$ \\
\hline 11 & 87,0 & 88,0 & 0,3535 \\
\hline 12 & 91,5 & 93,5 & 0,0949 \\
\hline 13 & 88,0 & 90,0 & 0,1202 \\
\hline
\end{tabular}

Diferenças estatisticamente significantes:

$\mathrm{P}<0,05^{*}$

$\mathrm{P}<0,01^{* *}$ 
Tabela 7 -Valores médios normais (padrão) das inclinações axiais mesiodistais de cada dente individualmente, médias dos valores obtidos ao término do tratamento ortodôntico (T2) e níveis de probabilidade de significância $(P)$.

\begin{tabular}{c|c|c|c}
\hline DENTE & Média Padrão & Média T2 & P \\
\hline 43 & 88,0 & 82,0 & $<0,0001^{* *}$ \\
\hline 33 & 87,0 & 82,0 & $0,0014^{* *}$ \\
\hline 23 & 87,0 & 86,0 & 0,3300 \\
\hline 22 & 90,5 & 88,0 & $0,0299 *$ \\
\hline 21 & 86,5 & 86,0 & 0,1224 \\
\hline 11 & 87,0 & 87,0 & 0,3781 \\
\hline 12 & 91,5 & 91,0 & 0,7195 \\
\hline 13 & 88,0 & 87,5 & 0,7560 \\
\hline
\end{tabular}

Diferenças estatisticamente significantes:

$\mathrm{P}<0,05^{*}$

$\mathrm{P}<0,01 * *$ 
Tabela 8 -Valores médios normais (padrão) das inclinações axiais mesiodistais de cada dente individualmente, médias dos valores obtidos ao início (T1) e ao término do tratamento ortodôntico (T2).

\begin{tabular}{c|c|c|c}
\hline DENTE & Média T1 & Média T2 & Média Padrão \\
\hline 43 & 89,0 & 82,0 & 88,0 \\
\hline 33 & 92,0 & 82,0 & 87,0 \\
\hline 23 & 89,5 & 86,0 & 87,0 \\
\hline 22 & 95,0 & 88,0 & 90,5 \\
\hline 21 & 88,0 & 86,0 & 86,5 \\
\hline 11 & 88,0 & 87,0 & 87,0 \\
\hline 12 & 93,5 & 91,0 & 91,5 \\
\hline 13 & 90,0 & 87,5 & 88,0 \\
\hline
\end{tabular}



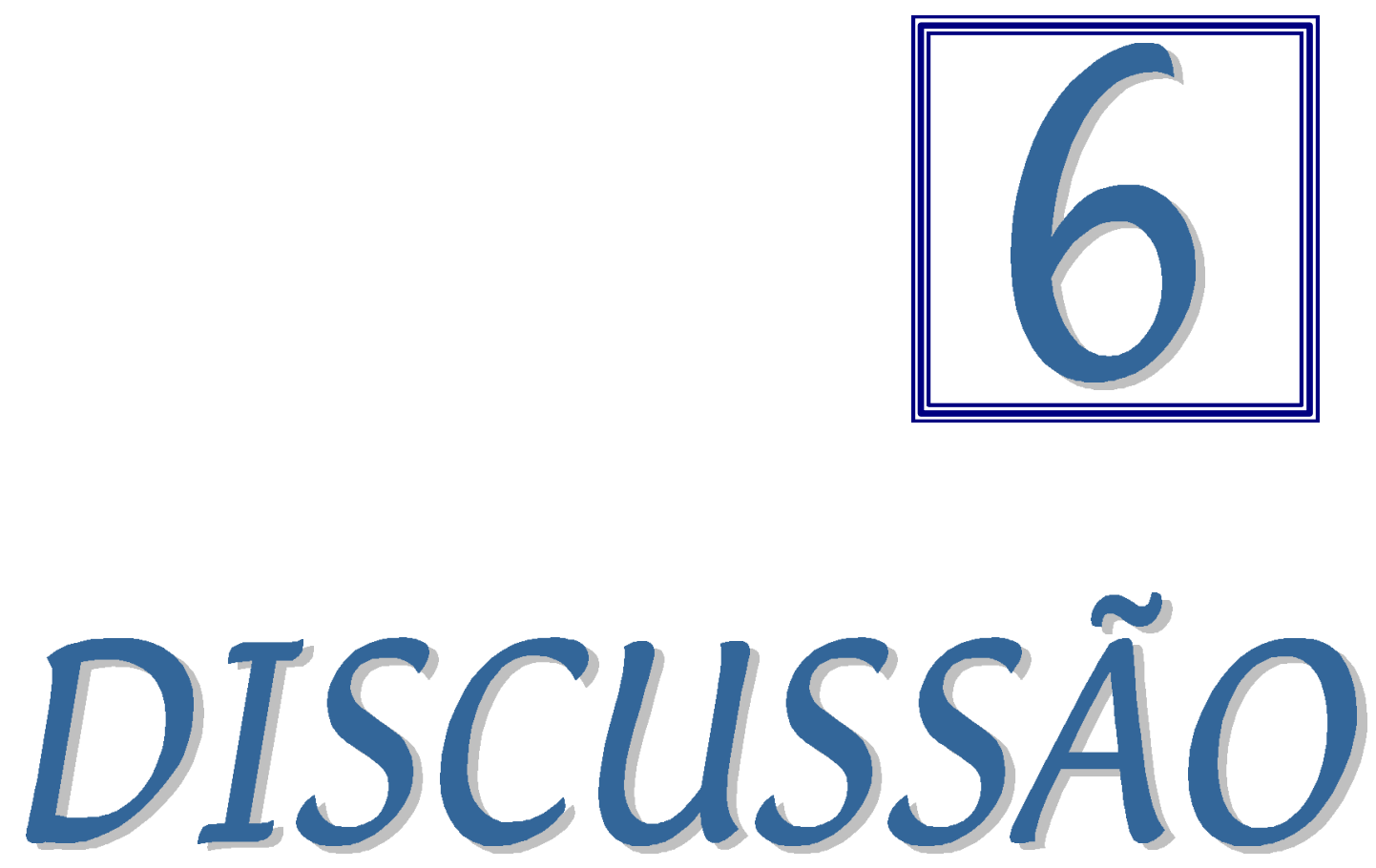


\section{6. - DISCUSSÃOO}

Precedendo a discussão específica dos resultados do presente estudo, julgou-se conveniente tecer algumas considerações a respeito do erro metodológico. Assim, dividiu-se este capítulo em três partes, discutindo o erro do método, o método radiográfico e a inclinação axial mesiodistal.

\section{1- Do erro metodológico}

O estudo radiográfico, panorâmico ou cefalométrico, apresenta-se como um inestimável recurso para o diagnóstico, planejamento e acompanhamento ortodôntico. No entanto, para a utilização destas radiografias em pesquisas científicas, torna-se necessário a determinação do erro proveniente dos procedimentos envolvidos no traçado radiográfico, na demarcação dos pontos e na leitura das medidas avaliadas ${ }^{51}$.

HOUSTON ${ }^{51}$ classificou os erros metodológicos em dois tipos: erro sistemático e casual. Para a verificação da significância estatística do erro sistemático utilizou-se o teste t de Student e do erro casual a fórmula de DAHLBERG ${ }^{29}$. 
Para a interpretação do erro casual, baseando-se nas pesquisas de SANDLER ${ }^{83}$ e de LIU; GRAVELLY ${ }^{61}$ considerou-se os valores do índice de Dahlberg acima de $1,5^{\circ}$ como erros significantes.

Diante destas considerações observou-se que os resultados obtidos (tabelas 1 e 2) apresentaram-se dentro dos parâmetros aceitáveis não comprometendo os resultados e conclusões deste estudo.

\section{2- Do método radiográfico}

A partir do desenvolvimento e aprimoramento das radiografias panorâmicas, empreendidas principalmente por PAATERO ${ }^{70,71,72}$, que em 1961, criou o primeiro ortopantomógrafo, com o advento dos estudos de vários pesquisadores ${ }^{9,93}$, a técnica radiográfica tornou-se fundamental e imprescindível como meio auxiliar de diagnóstico em todas as áreas da odontologia. Desde então, desenvolveram-se diversas pesquisas referentes à quantidade de radiação, às vantagens e indicações da técnica, às distorções das estruturas anatômicas e ao aperfeiçoamento dos aparelhos no sentido de melhorar a qualidade da imagem. 
Os principais motivos da difusão da técnica encontram-se relacionados à operacionalidade, à simplicidade de uso aliada ao posicionamento do paciente no aparelho, à pequena dosagem de radiação e ao diminuto tempo de exposição ao paciente $\mathrm{e}^{16,21,38,53,57,74}$.

Em vista da grande versatilidade da radiografia panorâmica e as diversas possibilidades de seu emprego em odontologia, observa-se uma enorme divulgação do método em pesquisas e diagnósticos de lesões patológicas ${ }^{17,21}$, fraturas e cirurgias mandibulares ${ }^{17,21}$, cáries extensas ${ }^{69}$, determinação da posição do forame mentoniano ${ }^{66,76}$, exames rotineiros da cavidade bucal ${ }^{16,67}$ e diagnóstico clínico ${ }^{27}$.

Em ortodontia, vem sendo amplamente utilizada no acompanhamento das extrações seriadas ${ }^{43,97}$, no diagnóstico e plano de tratamento $^{19}$, na pesquisa de reabsorções radiculares ${ }^{49,65}$, no diagnóstico das condições dos dentes não irrompidos ou impactados, principalmente os terceiros molares ${ }^{45,54,97}$, nos estudos sobre o padrão de desenvolvimento oclusal e irrupção dentária ${ }^{15,46,49,55,67,97}$, na avaliação do paralelismo radicular $37,43,45,49,56,65,67,97$, na aferição e documentação da movimentação dentária induzida ${ }^{49,55}$, na 
apreciação das relações entre as coroas e as raízes dentárias e entre os dentes decíduos e os permanentes ${ }^{40}$, na mensuração da perda de ancoragem ${ }^{49,56}$, na visualização de dentes supranumerários ou agenesias dentárias ${ }^{1,43,47}$, na determinação das inclinações axiais dos segundos molares superiores ${ }^{14}$ e inferiores $^{34}$ impactados contra os primeiros molares, na avaliação do posicionamento dos terceiros molares ${ }^{85}$, nas pesquisas do padrão de crescimento $^{2,5,6}$, bem como para observar as inclinações dentárias axiais durante o tratamento ortodôntico $23,90,91$.

Em relação à avaliação das inclinações axiais dentárias, observam-se poucos estudos, sendo os mesmos referentes aos padrões de oclusão normal. A pesquisa desenvolvida por MLYNARSKA-ZDUANIAK ${ }^{68}$ estabeleceu médias e desvios padrão para as inclinações axiais dos longos eixos dos dentes permanentes, irrompidos ou não, de crianças com oclusão normal. O trabalho desenvolvido por $\mathrm{URSI}^{90}$, em brasileiros, com a finalidade específica de estabelecer um padrão médio normal para as inclinações axiais mesiodistais de todos os dentes permanentes por meio das radiografias panorâmicas contribuiu enormemente para a prática ortodôntica. 
Baseando-se nas investigações de $\mathrm{URSI}^{90}{ }^{0}$, dispusemonos a estudar as inclinações axiais mesiodistais dos dentes ântero-superiores e caninos inferiores de jovens com má oclusão, a fim de verificar se ao término do tratamento ortodôntico estas inclinações apresentavam-se concordantes com o padrão médio normal.

Com relação às radiografias empregadas no estudo, salienta-se uma atenção especial à padronização, uma vez que, todas as radiografias foram obtidas em um mesmo aparelho e por um único operador, de maneira a lograr radiografias com bom valor de diagnóstico 6,40,63,69,71,82, com mínimas distorções, visto que o posicionamento inadequado do paciente no aparelho compromete a qualidade da imagem, aumentando as distorções e prejudicando a interpretação da radiografia $3,18,28,57,78,81,82$.

Referindo-se à metodologia para as mensurações das inclinações dentárias, a literatura compulsada, mostrou um estudo $^{88}$ que indicou duas distintas linhas de referência para as medições dos dentes superiores (linha interorbitária- 10) e inferiores (linha intermentoniana- IM).

A radiografia panorâmica, como qualquer outro tipo de radiografia extrabucal, apresenta distorções lineares com 
ampliação da imagem ${ }^{4,15,25,46,74}$, fato que se deve à sua geometria de formação onde o filme e a fonte de radiação não se mantêm constantes, tornando impossível o estabelecimento de um único fator de correção para toda a imagem ${ }^{80}$. Deste modo, a análise de medições lineares nas pesquisas clínicas, principalmente no sentido horizontal com distorções variando de 15 a 30 \%, parece inviável $8,15,28,58,59$.

Em contrapartida, as distorções angulares apresentam-se menores e menos críticas $^{8,37,59,64,73,82}$, tornando-se insignificantes quando se tomam os cuidados básicos em relação ao posicionamento de um mesmo paciente entre várias tomadas radiográficas, revelando assim, a possibilidade do emprego da radiografia panorâmica em estudos angulares com grande acuidade $2,59,64$. Sabe-se ainda que clinicamente, uma variação de 5 graus, entre uma avaliação e outra de um mesmo paciente, é aceitável ${ }^{37,73,82}$.

Não houve uma preocupação maior em relação às mínimas distorções angulares, pois avaliou-se apenas os dentes anteriores, sabendo que os dentes posteriores ${ }^{4,40,43}$ encontramse mais sujeitos às variações do padrão da imagem, em função do próprio funcionamento do aparelho. 
Portanto, para a determinação do ângulo goníaco ${ }^{2,25,59,64,73}$ e a avaliação das inclinações axiais mesiodistais dentárias ${ }^{22,23,68,90,91}$ a radiografia panorâmica mostrou-se um instrumento de grande valia.

\section{3- Da inclinação axial mesiodistal}

O correto posicionamento mesiodistal dos longos eixos dentários, contribui sobremaneira para alcançar o equilíbrio da oclusão e do sistema estomatognático, constituindo-se num fator relevante para a obtenção do perfeito alinhamento dos dentes em suas respectivas bases ósseas e para a manutenção da estabilidade dos resultados obtidos pelo tratamento ortodôntico ${ }^{11,32,48}$. Um caso tratado ortodonticamente, deve ao final do tratamento, apresentar a mesma inclinação axial encontrada na oclusão "normal"91.

Diversos estudos revelaram que, em uma oclusão normal, os dentes encontram-se em equilíbrio mantendo entre si uma arquitetura estrutural em relação ao posicionamento na cavidade bucal de acordo com sua função. Uma característica específica desta oclusão é a inclinação mesiodistal dos longos eixos dos dentes ${ }^{10,11,12,31,31,39,75,94}$ que, de maneira geral, 
apresentam-se inclinados, em graus variáveis para distal, conforme sua localização no arco dentário.

As distintas inclinações dentárias aliadas aos planos inclinados das cúspides dos dentes, contribuem para uma correta dissipação das forças oclusais ${ }^{12,41,42,84,94,96}$, que devem ser dirigidas o mais próximo possível dos longos eixos dos dentes ${ }^{13}$, de modo que, parte destas forças sejam decompostas por um componente anterior ${ }^{12,31,41,42}$, que se inicia nos dentes posteriores sendo neutralizada na linha média pela força homóloga proveniente do hemi-arco do lado oposto ${ }^{41}$.

Em relação aos aspectos ortodônticos, a correta inclinação axial mesiodistal dos dentes representa uma das chaves para obtenção dos objetivos do tratamento ${ }^{10,11}$. Pela literatura compulsada, evidenciou-se ainda a grande importância da inclinação axial mesiodistal nas seguintes situações: nos casos tratados com extrações onde não se obtém um paralelismo radicular adequado, há uma maior possibilidade de reabertura dos espaços fechados durante a terapia $32,44,48,50,60,62,65,79,86 ;$ alguns casos com discrepância de tamanho dentário positiva no segmento ântero-superior necessitam de um aumento das inclinações axiais destes dentes 
para distal objetivando um contato adequado entre eles ${ }^{89}$; um aumento para distal das inclinações radiculares dos incisivos inferiores pode melhorar a estabilidade do alinhamento dentário na região ântero-inferior ${ }^{95}$; o espaço adequado para cada dente no arco dentário varia de acordo com as inclinações axiais mesiodistais permitindo a obtenção de uma oclusão com contatos cerrados e um bom relacionamento ânteroposterior ${ }^{10,20}$.

A preocupação com a correção das inclinações axiais mesiodistais dos dentes após o tratamento ortodôntico nos motivou a desenvolver esta pesquisa. A avaliação restringiu-se aos dentes ântero-superiores e caninos inferiores, uma vez que todos os pacientes da amostra foram tratados com a técnica edgewise simplificada onde apenas os braquetes destes dentes devem ser angulados proporcionando um posicionamento artístico dos mesmos $24,50,52,92$.

Analisando os resultados do presente estudo, verificou-se nas seguintes figuras 12 e 13, que com exceção do incisivo central superior direito (11), para os outros dentes avaliados, a diferença entre as médias obtidas em T1 e T2 foi estatisticamente significante (tabela 5), demonstrando que o 
tratamento alterou o posicionamento mesiodistal dos longos eixos dos dentes. Embora o dente 11 não tenha apresentado diferença significante entre o início e término da terapia, sua inclinação em T2 alcançou o valor médio normal (tabelas 7 e 8).

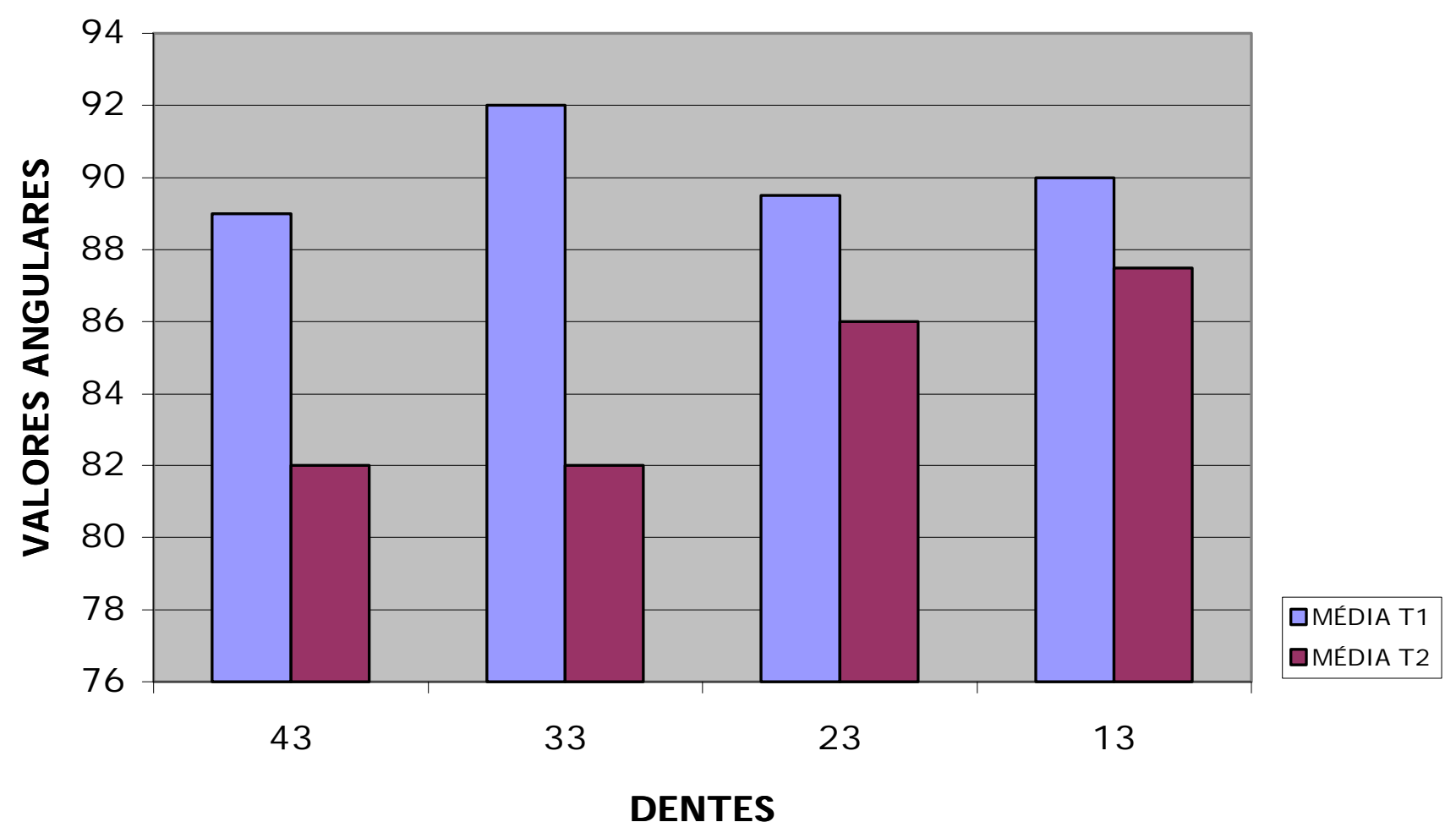

FIGURA 12 - Representação gráfica da correlação entre o valor médio em T1 e médio em T2 para os caninos inferiores e superiores. 


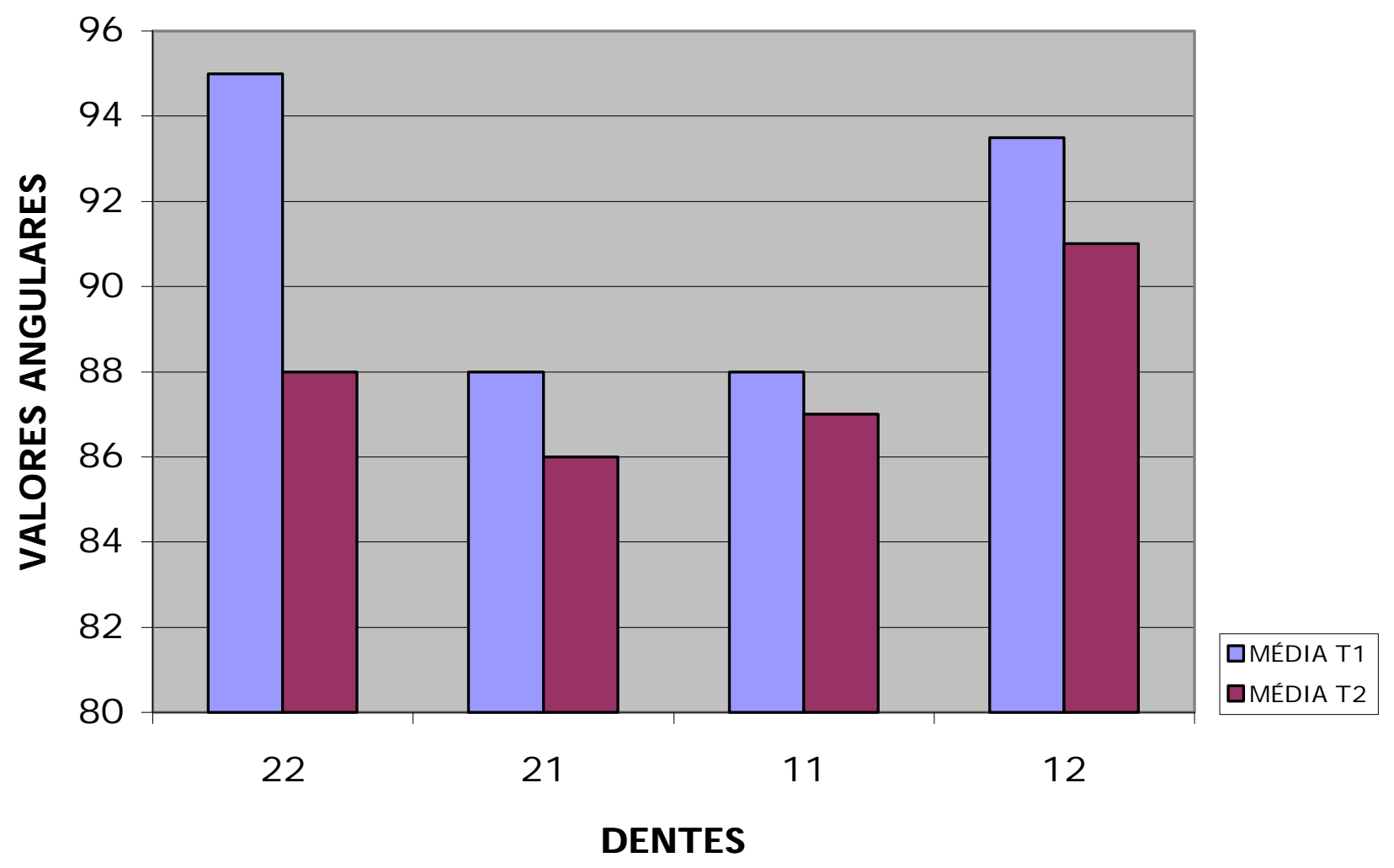

FIGURA 13 - Representação gráfica da correlação entre o valor médio em T1 e médio em T2 para os incisivos superiores. 
Comparando-se os valores médios normais e as médias dos valores obtidos em T1, evidenciamos nas figuras 14 e 15, que as inclinações dos dentes 33, 23, 22, e 21 não se apresentavam concordes com as configurações anatômicas normais (tabela 6) sendo necessárias suas correções durante o tratamento ortodôntico. A manutenção das inclinações axiais mesiodistais dos demais dentes bem posicionados radiograficamente, por outro lado, caracterizaria uma opção do tratamento.

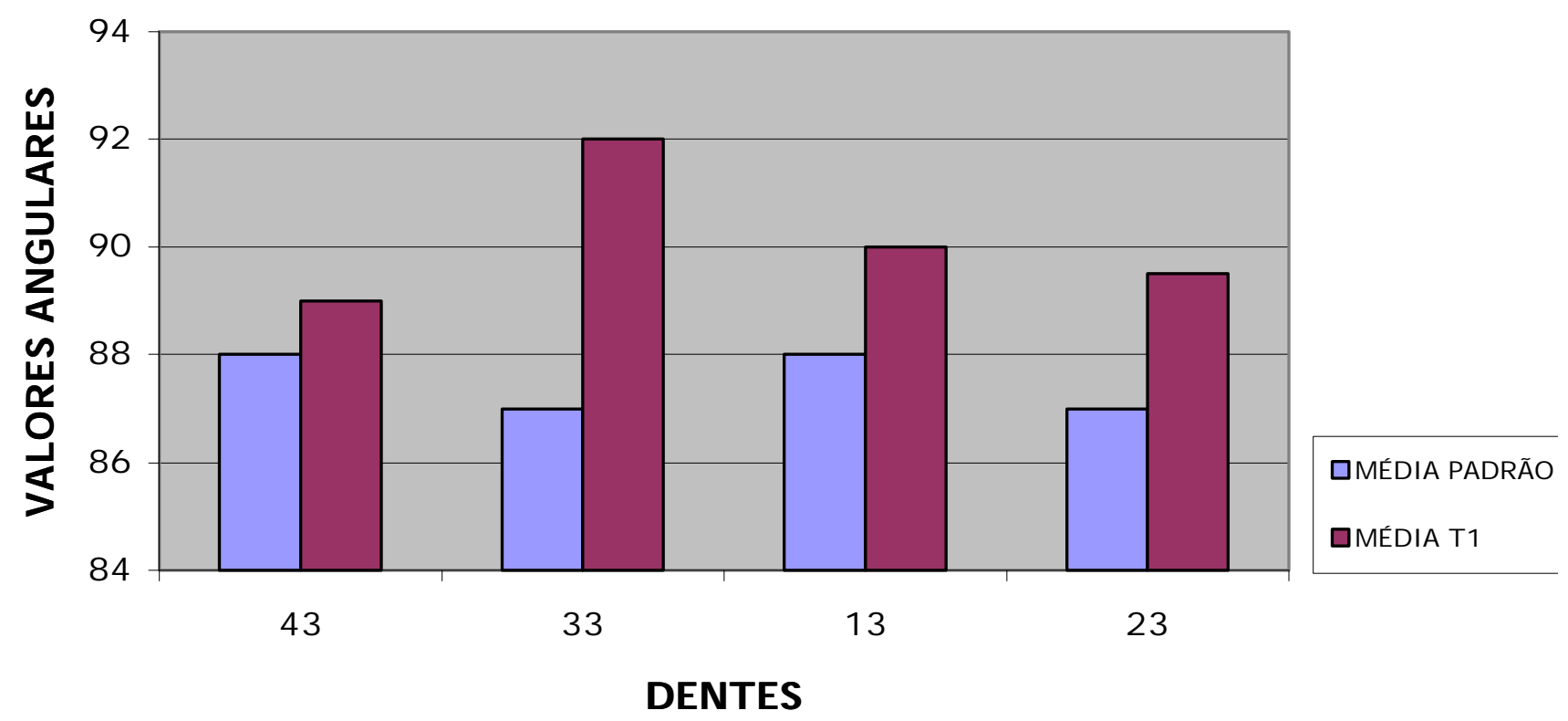

FIGURA 14 - Representação gráfica da correlação entre o valor médio padrão e médio em T1 para os caninos inferiores e superiores. 


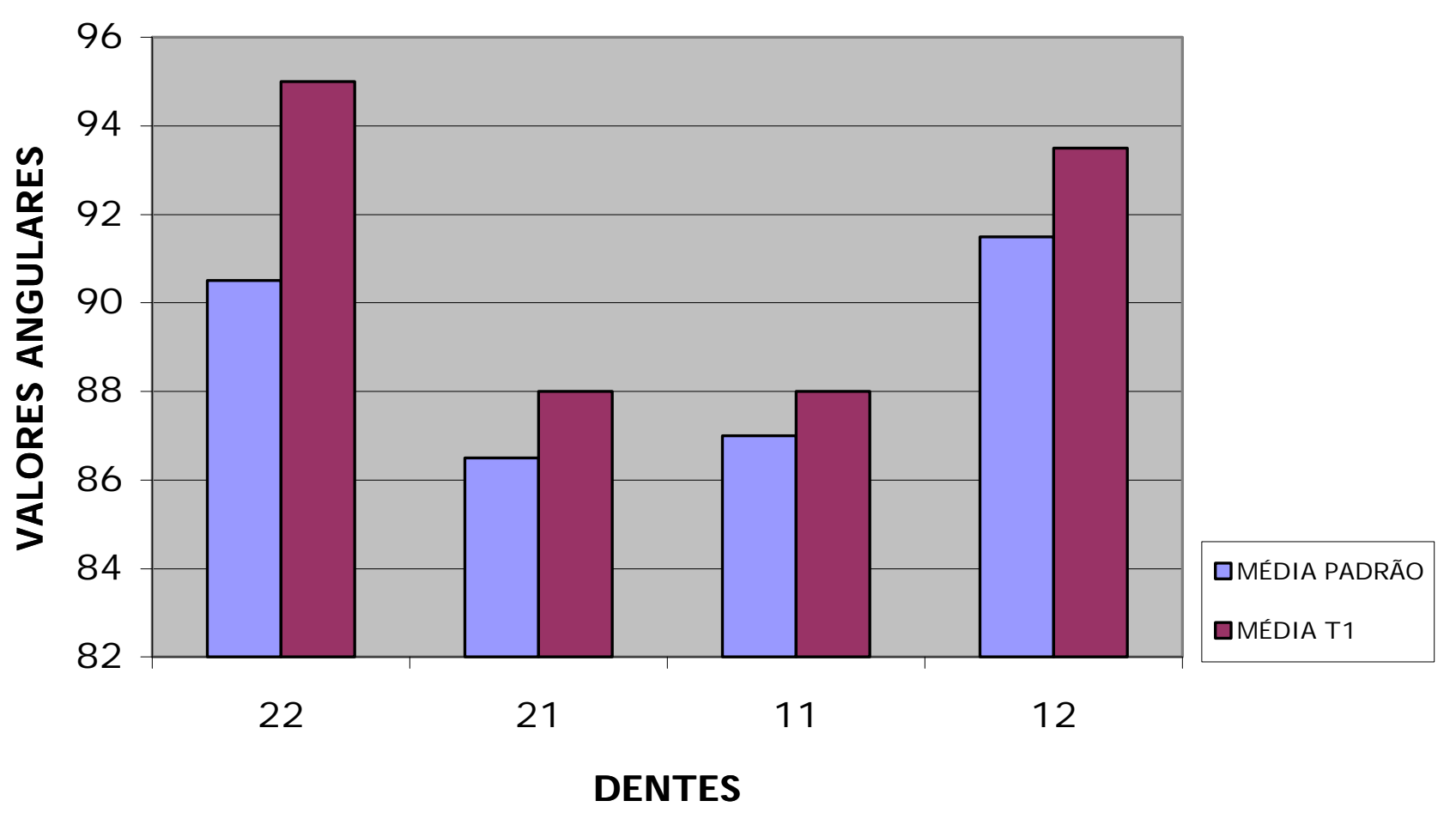

FIGURA 15 - Representação gráfica da correlação entre o valor médio padrão e médio em T1 para os incisivos superiores. 
Como objetivo principal desta investigação, compararam-se os valores do padrão médio normal com os valores obtidos das radiografias panorâmicas em T2 observando uma correspondência significante na maioria dos dentes avaliados (tabela 7 e figuras 16 e 17) denotando assim, uma efetividade da correção ortodôntica em relação ao posicionamento mesiodistal dos longos eixos dentários. Os dentes 33, 43 e 22 apresentaram ao final do tratamento uma sobrecorreção de suas inclinações axiais mesiodistais (tabelas 7 e 8 e figuras 18 e 19) sendo que o canino inferior direito, encontrava-se ao início do tratamento bem posicionado, em relação à inclinação mesiodistal, requerendo apenas a manutenção de sua inclinação inicial durante a terapêutica ortodôntica. 


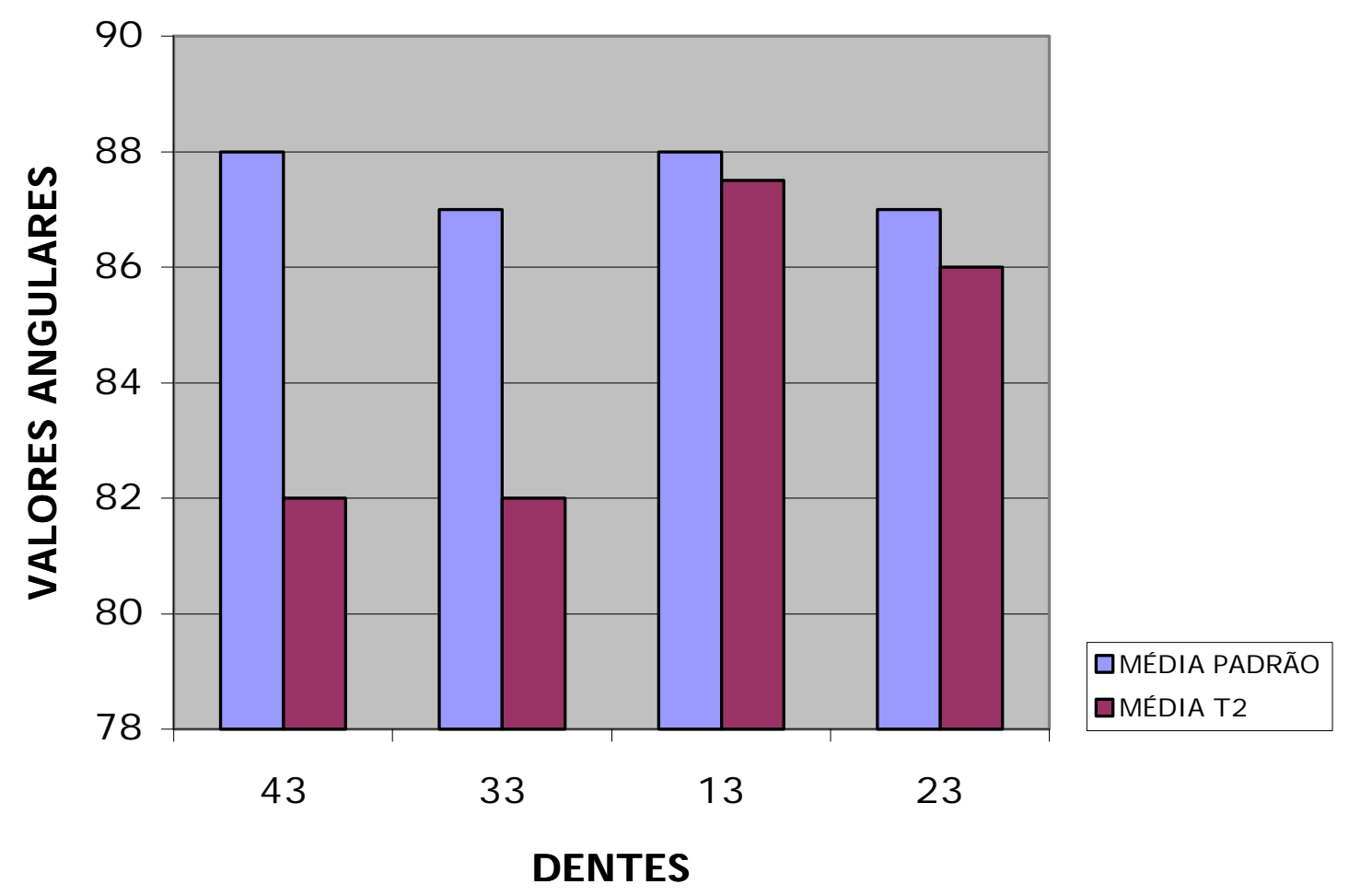

FIGURA 16 - Representação gráfica da correlação entre o valor médio padrão e médio em T2 para os caninos inferiores e superiores. 


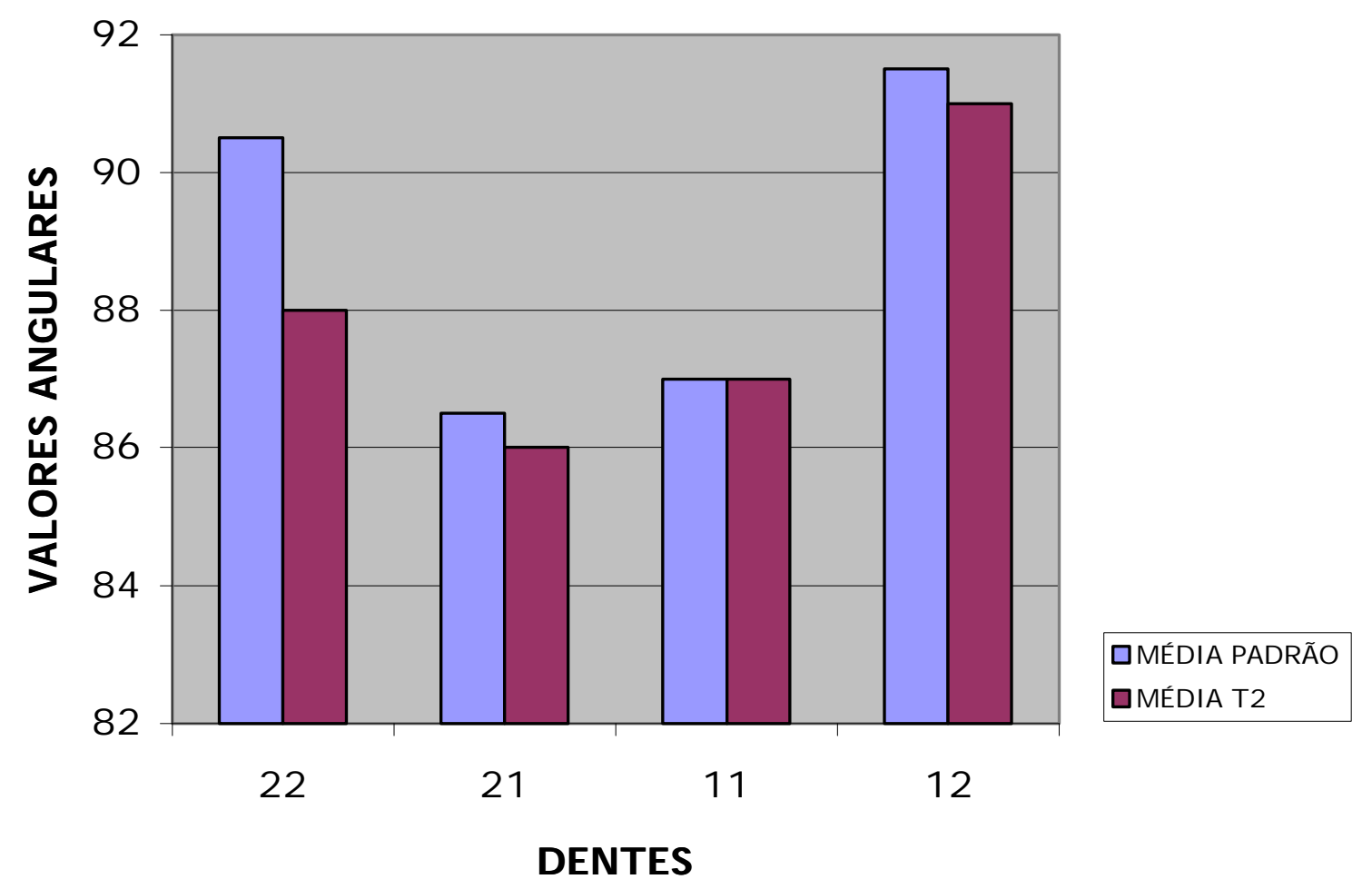

FIGURA 17 - Representação gráfica da correlação entre o valor médio padrão e médio em T2 para os incisivos superiores. 


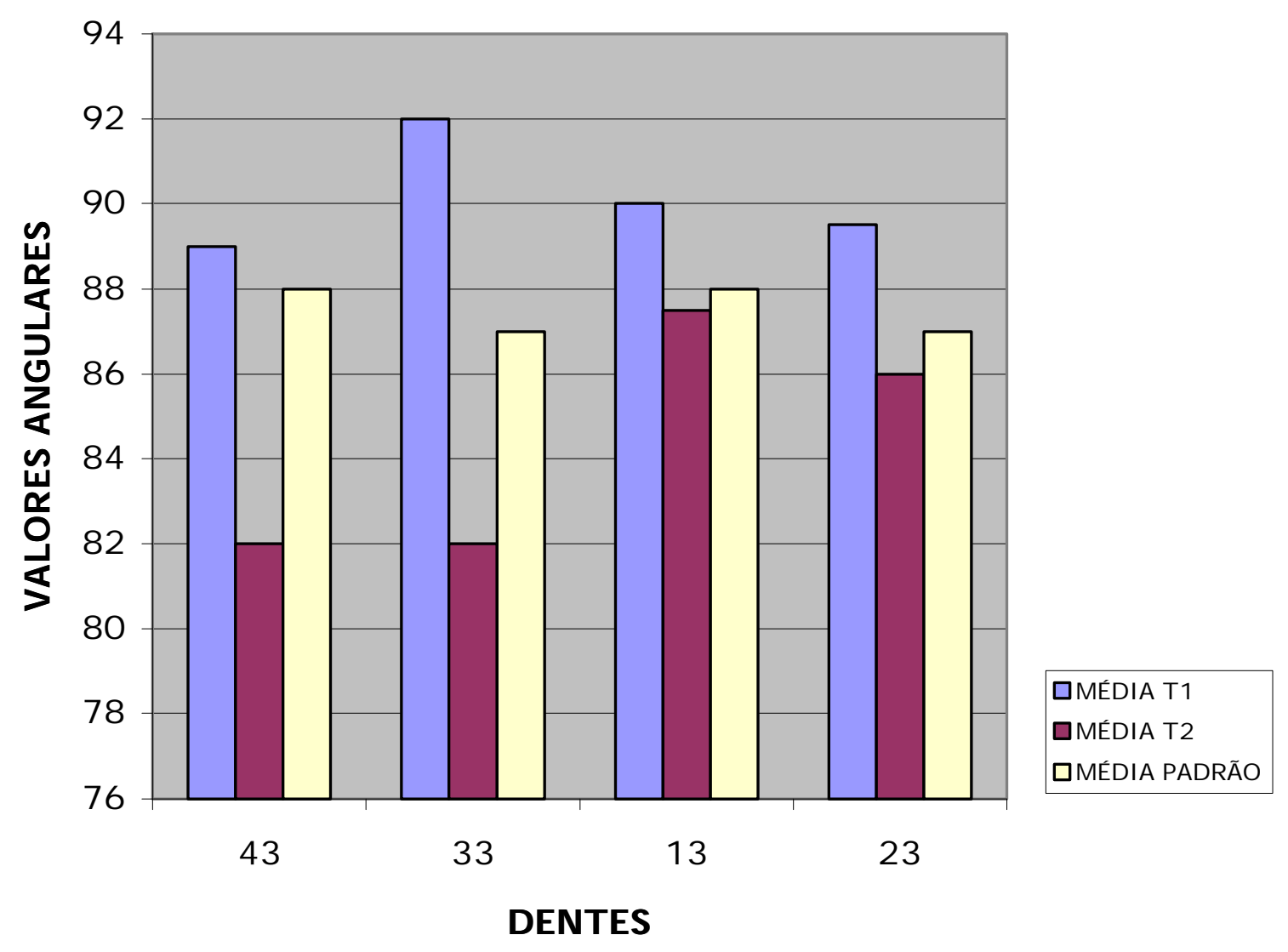

FIGURA 18 - Representação gráfica da correlação entre o valor médio padrão, médio em T1 e em T2 para os caninos inferiores e superiores. 


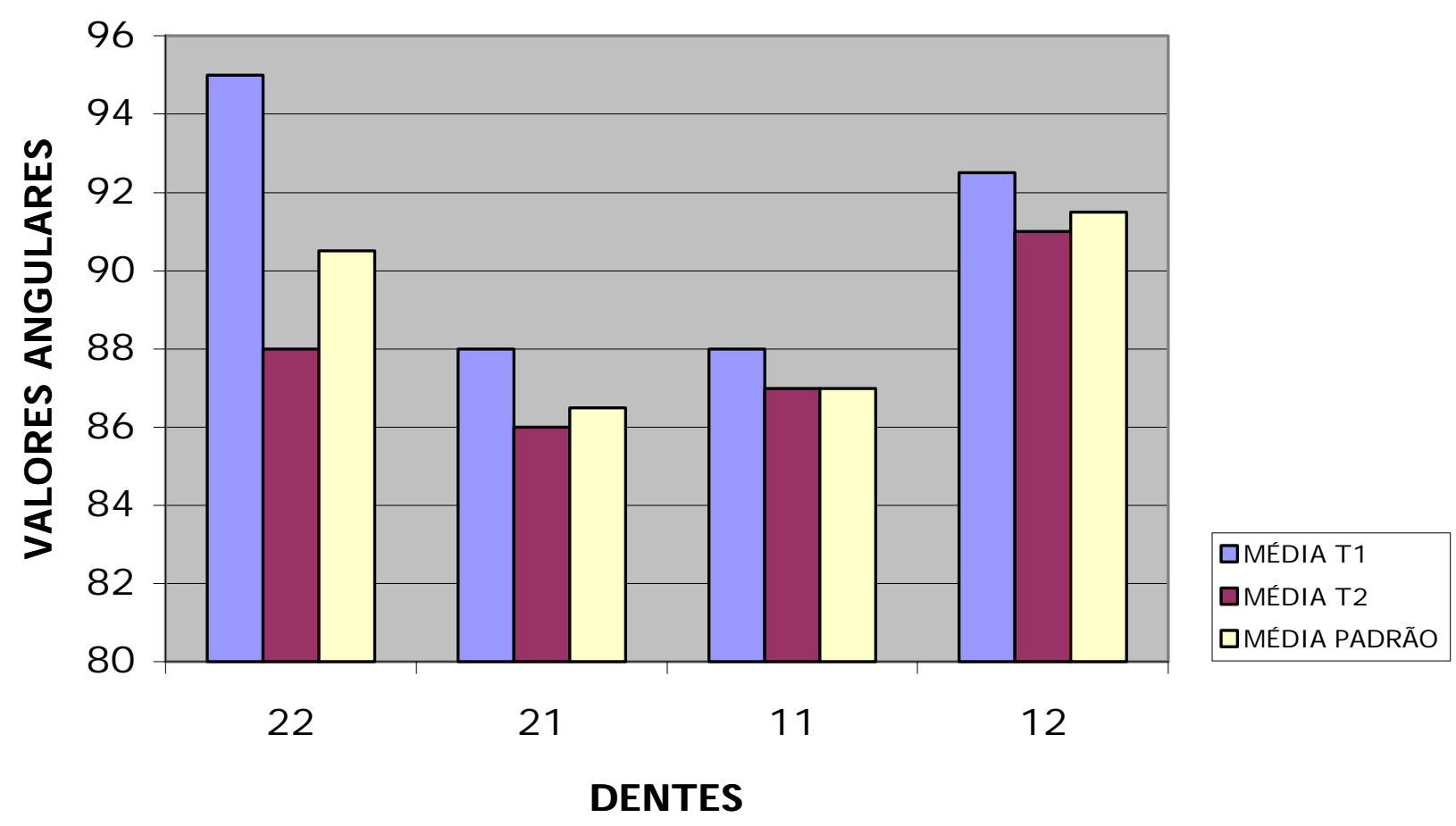

FIGURA 19 - Representação gráfica da correlação entre o valor médio padrão, médio em T1 e em T2 para os incisivos superiores. 
Portanto, o profissional deve atentar-se para as inclinações axiais mesiodistais dentárias, analisando-as clinicamente e também, sempre que possível, nas radiografias panorâmicas iniciais e intermediárias $22,23,90,91$ evitando assim sub ou sobrecorreções que provavelmente influenciariam na estabilidade dos casos.

A correta inclinação mesiodistal dos dentes ao final do tratamento ortodôntico tem sido buscada de diversas maneiras. Desde as dobras artísticas no fio retangular até a soldagem dos braquetes em posição angulada nas bandas preconizada por HOLDAWAY ${ }^{50}$ e posteriormente a colagem direta obedecendo os mesmos princípios ${ }^{52,92}$, a busca pela simplificação sem perder a qualidade tornou-se evidente.

Mesmo utilizando estes recursos, muitas vezes a individualidade se sobrepõe e alguns ajustes tornam-se necessários. Assim, uma atenção especial deve ser dada à montagem do aparelho ortodôntico, em relação ao posicionamento dos braquetes, uma vez que, os dentes podem apresentarem-se com adequada inclinação axial mesiodistal ao início do tratamento requisitando a individualização do aparelho. Sendo assim, os acessórios seriam posicionados 
paralelamente às bordas incisais ${ }^{77,92}$, sempre que se constatar boa posição dentária, com a finalidade de se manter a inclinação axial inicial. Em relação ao tratamento com a técnica straight wire que utiliza braquetes programados com as angulações ideais já incorporadas, uma individualização do aparelho talvez seria adequada ${ }^{24}$.

É de boa conduta também a avaliação das inclinações dentárias mesiodistais ao término do tratamento com o objetivo de controlar e avaliar as possíveis e tão freqüentes recidivas ortodônticas. Julga-se necessário, no entanto, futuras investigações para verificar se os casos tratados ortodonticamente que recidivaram, apresentaram-se, ao final do tratamento, com as inclinações axiais mesiodistais muito discrepantes do padrão médio normal. 


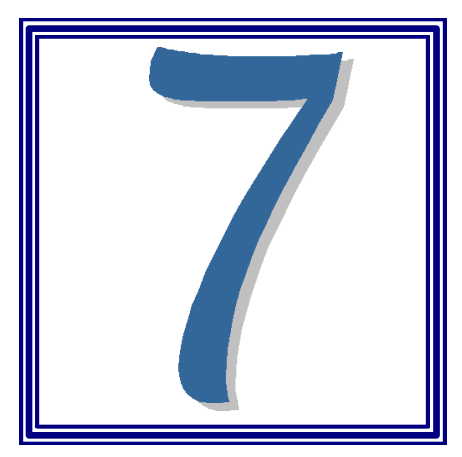

CONCLUSÕES 


\section{7 - CONCLUSÕES}

Dos resultados obtidos e considerando a literatura revista e discutida, pode-se concluir que:

* As inclinações axiais mesiodistais dos dentes ânterosuperiores e caninos inferiores, ao início do tratamento, mostraram-se diferentes daquelas observadas em uma oclusão normal, em $50 \%$ dos dentes avaliados.

* As inclinações ao final do tratamento apresentaram-se, em sua maioria, concordes com as configurações anatômicas normais descritas por URSI ${ }^{90}$.

* A radiografia panorâmica apresentou-se como um valioso instrumento para avaliações angulares antes e durante o tratamento, pois pode-se constatar com o auxílio desta, a necessidade de correção ou apenas da manutenção da inclinação axial mesiodistal, proporcionando desta forma, estabilidade e boa função oclusal. 


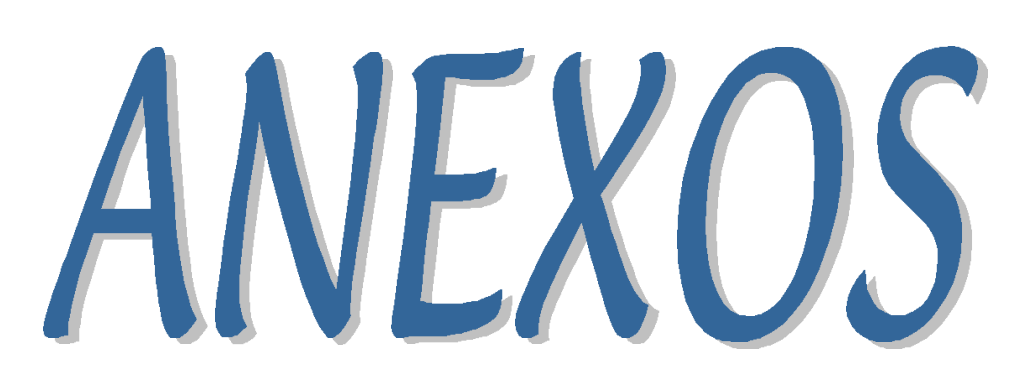


Anexo 1 - Valores amostrais, em graus das inclinações axiais mesiodistais dos dentes ântero-superiores e caninos inferiores ao início do tratamento.

\begin{tabular}{|c|c|c|c|c|c|c|c|c|}
\hline \multirow[t]{2}{*}{$\mathrm{N}^{\mathrm{o}}$ paciente } & \multicolumn{8}{|c|}{ Número do dente } \\
\hline & 13 & 12 & 11 & 21 & 22 & 23 & 33 & 43 \\
\hline 01 & 89,0 & 98,0 & 92,0 & 86,0 & 92,0 & 85,0 & 97,0 & 91,0 \\
\hline 02 & 91,0 & 92,0 & 85,0 & 86,0 & 96,0 & 94,0 & 100,0 & 84,0 \\
\hline 03 & 97,0 & 89,0 & 87,0 & 90,0 & 92,0 & 95,0 & 101,0 & 106,0 \\
\hline 04 & 88,5 & 90,0 & 88,0 & 90,0 & 94,0 & 88,0 & 85,0 & 81,0 \\
\hline 05 & 95,0 & 99,0 & 87,0 & 87,0 & 98,0 & 94,0 & 88,0 & 87,0 \\
\hline 06 & 93,0 & 93,0 & 89,0 & 85,0 & 95,0 & 92,0 & 102,0 & 95,0 \\
\hline 07 & 92,0 & 93,0 & 92,0 & 85,0 & 93,0 & 87,0 & 88,0 & 83,0 \\
\hline 08 & 84,0 & 100,0 & 88,5 & 87,0 & 102,0 & 87,0 & 81,0 & 79,0 \\
\hline 09 & 89,0 & 91,0 & 91,0 & 97,0 & 103,0 & 91,0 & 102,0 & 95,0 \\
\hline 10 & 94,0 & 92,0 & 89,5 & 88,0 & 94,0 & 92,0 & 87,0 & 90,0 \\
\hline 11 & 102,0 & 103,0 & 93,0 & 86,0 & 94,0 & 95,0 & 80,5 & 86,0 \\
\hline 12 & 86,0 & 97,0 & 89,5 & 84,0 & 96,0 & 84,0 & 78,0 & 81,0 \\
\hline 13 & 100,0 & 97,0 & 89,0 & 94,0 & 103,0 & 97,0 & 97,0 & 98,0 \\
\hline 14 & 90,0 & 85,0 & 90,0 & 85,0 & 89,0 & 93,0 & 86,0 & 89,0 \\
\hline 15 & 87,0 & 89,0 & 85,5 & 89,0 & 100,0 & 86,0 & 93,0 & 88,0 \\
\hline 16 & 83,0 & 95,0 & 87,0 & 94,0 & 99,0 & 89,0 & 86,0 & 82,0 \\
\hline 17 & 91,0 & 95,5 & 88,0 & 87,0 & 99,0 & 89,0 & 88,0 & 91,5 \\
\hline 18 & 92,0 & 91,0 & 92,0 & 88,0 & 89,0 & 84,5 & 91,0 & 97,0 \\
\hline 19 & 84,0 & 89,5 & 89,0 & 87,5 & 99,0 & 90,5 & 89,5 & 81,0 \\
\hline 20 & 83,5 & 85,0 & 86,0 & 88,0 & 83,0 & 84,5 & 87,0 & 95,0 \\
\hline 21 & 87,0 & 108,0 & 96,0 & 87,0 & 98,0 & 81,0 & 80,0 & 78,0 \\
\hline 22 & 80,0 & 78,0 & 77,0 & 89,5 & 90,0 & 89,0 & 89,0 & 91,0 \\
\hline 23 & 80,0 & 98,0 & 86,0 & 88,0 & 96,0 & 83,0 & 85,0 & 85,0 \\
\hline 24 & 95,0 & 92,5 & 88,0 & 94,0 & 103,0 & 93,0 & 101,0 & 91,0 \\
\hline 25 & 93,0 & 94,0 & 87,0 & 91,0 & 96,0 & 98,0 & 97,0 & 89,0 \\
\hline 26 & 80,0 & 86,0 & 82,0 & 84,0 & 93,0 & 76,0 & 98,0 & 90,5 \\
\hline 27 & 84,0 & 90,5 & 83,0 & 89,0 & 97,0 & 89,0 & 93,0 & 83,0 \\
\hline 28 & 97,0 & 103,0 & 95,0 & 92,0 & 101,5 & 95,0 & 96,0 & 95,0 \\
\hline 29 & 99,0 & 102,0 & 93,0 & 82,0 & 90,5 & 84,0 & 93,0 & 81,0 \\
\hline 30 & 97,0 & 92,0 & 86,0 & 89,5 & 87,5 & 100,0 & 100,0 & 91,0 \\
\hline 31 & 82,0 & 88,0 & 86,0 & 88,0 & 91,0 & 89,0 & 93,0 & 84,0 \\
\hline 32 & 78,0 & 89,0 & 96,0 & 84,0 & 89,0 & 81,0 & 98,0 & 95,0 \\
\hline 33 & 88,0 & 89,0 & 90,0 & 91,0 & 90,0 & 90,0 & 89,0 & 84,0 \\
\hline 34 & 97,0 & 97,0 & 86,0 & 84,0 & 91,0 & 93,0 & 88,0 & 79,0 \\
\hline 35 & 90,0 & 98,0 & 86,0 & 82,0 & 87,0 & 81,0 & 93,5 & 94,5 \\
\hline 36 & 87,0 & 91,0 & 89,0 & 89,0 & 92,0 & 88,0 & 91,0 & 88,0 \\
\hline 37 & 91,0 & 85,0 & 86,0 & 86,0 & 92,0 & 94,0 & 95,0 & 89,0 \\
\hline 38 & 86,0 & 95,0 & 92,0 & 93,0 & 100,0 & 94,5 & 94,5 & 91,0 \\
\hline 39 & 97,0 & 103,0 & 84,0 & 87,0 & 99,0 & 97,0 & 98,0 & 95,0 \\
\hline 40 & 93,0 & 94,0 & 87,0 & 93,5 & 101,0 & 81,0 & 94,0 & 101,0 \\
\hline
\end{tabular}


Anexo 2 - Valores amostrais, em graus das inclinações axiais mesiodistais dos dentes ântero-superiores e caninos inferiores ao término do tratamento.

\begin{tabular}{|c|c|c|c|c|c|c|c|c|}
\hline $\mathrm{N}^{\circ}$. paciente & \multicolumn{8}{|c|}{ Número do dente } \\
\hline & 13 & 12 & 11 & 21 & 22 & 23 & 33 & 43 \\
\hline 01 & 89,0 & 90,0 & 88,0 & 82,0 & 82,0 & 82,0 & 79,5 & 73,0 \\
\hline 02 & 84,0 & 88,5 & 88,0 & 92,0 & 91,0 & 88,0 & 84,0 & 77,0 \\
\hline 03 & 91,0 & 91,0 & 85,0 & 82,0 & 83,0 & 86,0 & 75,0 & 78,0 \\
\hline 04 & 87,0 & 87,0 & 86,0 & 93,0 & 96,0 & 96,0 & 95,0 & 74,0 \\
\hline 05 & 90,0 & 93,0 & 85,0 & 82,5 & 86,0 & 86,0 & 74,0 & 89,0 \\
\hline 06 & 94,0 & 101,0 & 89,0 & 87,0 & 83,0 & 82,0 & 79,0 & 83,0 \\
\hline 07 & 90,0 & 95,0 & 92,0 & 87,0 & 91,0 & 89,0 & 92,0 & 89,0 \\
\hline 08 & 89,5 & 89,0 & 87,0 & 86,0 & 86,5 & 85,0 & 65,0 & 72,0 \\
\hline 09 & 87,0 & 93,0 & 85,0 & 87,0 & 96,0 & 82,0 & 79,0 & 79,0 \\
\hline 10 & 89,0 & 91,0 & 87,0 & 89,0 & 93,0 & 90,0 & 84,0 & 75,0 \\
\hline 11 & 84,0 & 95,0 & 82,0 & 85,0 & 90,5 & 81,0 & 76,0 & 78,5 \\
\hline 12 & 97,0 & 96,0 & 94,0 & 83,0 & 94,0 & 90,0 & 83,5 & 85,0 \\
\hline 13 & 76,0 & 86,0 & 84,5 & 88,0 & 96,5 & 85,0 & 77,0 & 83,5 \\
\hline 14 & 82,0 & 84,0 & 80,5 & 91,0 & 90,5 & 88,0 & 88,0 & 92,0 \\
\hline 15 & 93,0 & 91,5 & 87,0 & 84,0 & 90,0 & 86,0 & 75,0 & 87,0 \\
\hline 16 & 91,0 & 96,0 & 88,0 & 86,0 & 90,0 & 89,0 & 72,0 & 83,0 \\
\hline 17 & 88,0 & 96,0 & 93,5 & 88,0 & 91,5 & 86,5 & 82,0 & 77,5 \\
\hline 18 & 83,0 & 87,0 & 90,5 & 87,0 & 87,0 & 88,0 & 87,0 & 90,5 \\
\hline 19 & 84,0 & 88,0 & 87,5 & 89,0 & 87,0 & 85,0 & 84,0 & 78,0 \\
\hline 20 & 83,0 & 87,0 & 89,0 & 88,0 & 88,0 & 86,0 & 82,5 & 88,0 \\
\hline 21 & 91,0 & 92,0 & 86,5 & 81,0 & 82,0 & 86,0 & 79,5 & 75,0 \\
\hline 22 & 83,0 & 85,0 & 86,0 & 84,0 & 86,5 & 86,0 & 78,0 & 83,0 \\
\hline 23 & 81,0 & 86,0 & 82,0 & 84,0 & 85,0 & 78,0 & 80,0 & 84,0 \\
\hline 24 & 81,0 & 85,0 & 84,0 & 91,0 & 91,0 & 89,0 & 87,0 & 82,0 \\
\hline 25 & 92,0 & 93,0 & 87,0 & 87,0 & 95,0 & 91,0 & 92,0 & 90,0 \\
\hline 26 & 93,0 & 93,0 & 87,0 & 83,0 & 85,0 & 86,0 & 87,0 & 81,0 \\
\hline 27 & 92,0 & 94,0 & 89,0 & 84,0 & 81,0 & 79,0 & 87,0 & 86,0 \\
\hline 28 & 88,0 & 95,0 & 88,0 & 90,0 & 94,0 & 90,0 & 84,0 & 91,0 \\
\hline 29 & 92,0 & 95,0 & 87,5 & 81,5 & 85,0 & 81,0 & 85,5 , & 81,0 \\
\hline 30 & 89,0 & 98,0 & 86,0 & 78,0 & 88,0 & 87,5 & 82,0 & 82,5 \\
\hline 31 & 86,0 & 89,0 & 85,0 & 86,0 & 91,0 & 88,0 & 84,0 & 82,0 \\
\hline 32 & 86,5 & 87,5 & 88,0 & 85,5 & 93,0 & 85,0 & 80,5 & 88,0 \\
\hline 33 & 74,0 & 82,0 & 84,0 & 89,0 & 82,0 & 77,0 & 83,5 & 83,5 \\
\hline 34 & 87,0 & 85,0 & 85,0 & 83,0 & 86,0 & 87,5 & 73,0 & 72,0 \\
\hline 35 & 92,0 & 101,0 & 90,0 & 86,0 & 89,0 & 89,0 & 69,0 & 76,0 \\
\hline 36 & 90,0 & 91,0 & 91,5 & 80,0 & 78,0 & 75,0 & 90,0 & 89,0 \\
\hline 37 & 79,0 & 79,0 & 83,0 & 83,0 & 83,0 & 82,0 & 89,0 & 84,0 \\
\hline 38 & 89,0 & 99,5 & 94,0 & 83,0 & 83,0 & 84,5 & 87,0 & 85,0 \\
\hline 39 & 87,0 & 95,0 & 85,0 & 86,0 & 92,0 & 94,0 & 72,0 & 69,0 \\
\hline 40 & 87,0 & 94,0 & 89,0 & 85,5 & 83,0 & 84,0 & 93,0 & 89,5 \\
\hline
\end{tabular}




\section{REFERÊNCIAS BIBLIOGRÁFICAS}




\section{REFERÊNCIAS BIBLIOGRÁFICAS *}

1. ALMEIDA, R.R.; VASCONCELOS, M.H.F.; INSABRALDE, C.M.B. Importância das radiografias panorâmicas intermediárias em tratamentos ortodônticos. Rev. Fac. Odont. Lins, v.1, n.1, p.17-20, 1988.

2. ALMEIDA, R.R. et al. Determinação do ângulo goníaco: teler radiografia x ortopantomografia. Rev. Odont. USP, v.5, n.2, p.118-23, 1991.

3. ALMEIDA, S.M.; BÓSCOLO, F.N.; HAITER NETO, F. Erros em radiografias panorâmicas. Rev. Odont. Brasil CentralROBRAC, v.5, n.16, p.25-9, 1995.

4. ALMEIDA, S.M.; BÓSCOLO, F.N.; MONTEBELLO FILHO, A. Estudo das distorções da imagem produzida em aparelhos panorâmicos que se utilizam dos princípios ortopantomográficos e elipsopantomográficos. Rev. Odont. USP, v.9, n.2, p.91-9, 1995.

\footnotetext{
* Normas recomendadas para uso no âmbito da Universidade de São Paulo, com base no documento "Referencias Bibliográficas: exemplos", emanado do Conselho Supervisor do Sistema Integrado de Biblioteca da USP, em reunião de 20 de setembro de 1990.
} 
5. ALPERN, M.C. Analysis of panoramic cephalometrics using a skeletal cephalostat. Angle Orthodont., v.49, n.2, p.110-20, 1979.

6. ALPERN, M.C. Clinical radiography in the orthodontic practice. Angle Orthodont., v.54, n.3, p.233-46, 1984.

7. ALVARES, L.C.; TAVANO, O. Curso de radiologia em odontologia. 3.ed. São Paulo, Editora Santos, 1993.

8. AMIR, C. et al. Evaluation of the precision of dimensional measurements of the mandible on panoramic radiographs. Oral Surg., v.86, n.2, p.242-8, 1998.

9. ANDREWS, J.R. apud KANE, E.G. ${ }^{55}$ p.16.

10. ANDREWS, L.F. The six keys to normal occlusion. Amer. J. Orthodont., v.62, n.3, p.296-309, 1972.

11. ANDREWS, L.F. The diagnostic system: occlusal analysis. Dent. Clin. N. Amer., v.20, n.4, p.671-90, 1976.

12. BERKOVITZ, B.K.B.; HOLLAND, G.R.; MOXHAM, B.J. The alignment and occlusion of the permanent teeth. $\ln$ : - A colour atlas \& textbook of oral anatomy. London, Wolfe Medical, 1978. p. 35-41. 
13. BEYRON, H.L. Occlusal relationship. Int. dent. 」., v.2, n.4, p.467-96, 1952.

14. BJERKLIN, K; KUROL, J. Ectopic eruption of the maxillary first permanent molars: etiologic factors. Amer. 1. Orthodont., v.84, n.2, p.147-55, 1983.

15. BLACKMAN, S. Mass dental radiography. Radiography, v.22, p.21-5, 1956 .

16. BLACKMAN, S. Rotational tomography of the face. Brit. ]. Radiol., v.33, p.408-18, 1960.

17. BLACKMAN, S. Panoramic radiography. Brit. J. oral Surg., v.1, p. 209-18, 1963.

18. BREZDEN, N.A.; BROOKS, S.L. Evaluation of panoramic dental radiographs taken in private practice. Oral Surg., v.63, p.617-21, 1987.

19. BRUKS, A. et al. Radiographic examinations as an aid to orthodontic diagnosis and treatment planning. Swed. dent. J., v.23, n.2/3, p.77-85, 1999. 
20. CAMPOS JUNIOR, A. Distribuiçãa fotoelástica de forças axiais: influência das oclusões cúspide-fossa e cúspidecrista marginal, sob periodonto normal e debilitado (antes e após esplintagem). Bauru, 1986. 149p. Tese (Doutorado) - Faculdade de Odontologia de Bauru, Universidade de São Paulo.

21. CAPELLI, J. et al. Avaliação de interesse clínico entre a radiografia panorâmica e o conjunto periapical aplicado à clínica odontológica. Rev. Inst. Cienc. Saúde, v.9, n.2, p.59-68, 1991.

22. CAPELOZZA FILHO, L; MACHADO, G.B. Inclinação axial mésio-distal do primeiro molar superior na ortopantomografia: sugestão de modificação do método de avaliação. Rev. Soc. bras. Ortodont., v.2, n.5, p.142-4, 1994.

23. CAPELOZZA FILHO, L. et al. Angulação dentária após o tratamento ortodôntico pela técnica de Andrews e Edgewise: avaliação pela ortopantomografia. Ortodontia, v.27, n.2, p.60-6, 1994. 
24. CAPELOZZA FILHO, L. et al. Individualização de braquetes na técnica de straight wire: revisão de conceitos e sugestão de indicações para uso. Rev. Dental Press Ortodon. Ortop. Facial, v.4, n.4, p.87-106, 1999.

25. CARVALHO, P.L. et al. Estudo radiográfico comparativo das ampliações de segmentos ósseos crânio-faciais em crânios nas ortopantomografias e elipsopantomografias. Rev. Odont. USP, v.8, n.3, p.20510, 1994.

26. CAVALCANTI, M.G.P. et al. Estudo radiográfico comparativo de grandezas lineares maxilo-mandibulares por meio de elipsopantomografias e telerradiografias frontais em leucodermas e descendentes de japoneses. Rev. Odont. USP. v.7, n.2, p.115-9, 1993.

27. CHILES, J.L.; GORES, R.J. Anatomic interpretation of the orthopantomogram. Oral Surg., v.35, n.4, p.564-74, 1973.

28. CHRISTEN, A.G.; SEGRETO, V.A. Distortion and artifacts encountered in panorex radiography. L. Amer. dent. Ass., v.77, p. 1096-101, 1968. 
29. DAHLBERG, G. Statistical methods for medical and biological students. New York, Interscience, 1940.

30. DEMPSTER, W.T. et al. Arrangement in the jaws of the roots of the teeth. L. Amer. dent. Ass., v.67, p.779-97, 1963.

31. DEWEL, B.F. Clinical observations on the axial inclination of teeth. Amer. J. Orthodont., v.35, n.2, p.98-115, 1949.

32. EDWARDS, J.G. The prevention of relapse in extraction cases. Amer. J. Orthodont., v.60, n.2, p.128-41, 1971.

33. ENACAR, A.; ALTAY, O.T.; HAYDAR, B. Orthodontic intervention in adult patients as an adjunct to prosthetic and restorative dentistry. J. Nihon Univ. Sch. Dent., v.34, n.1, p.50-6, 1992.

34. EVANS, R. Incidence of lower second permanent molar impaction. Brit. J. Orthodont., v.15, p.199-203, 1988. 
35. FREITAS, J.A.S. Estudo antropométrico, dentário e ósseo de brasileiros de três a dezoito de idade, da região de Bauru. Bauru, 1975. 185p. Tese (Livre-Docência) Faculdade de Odontologia de Bauru, Universidade de São Paulo.

36. FREITAS, A.; ROSA, J.E.; SOUZA, I.F. Radiologia odontológica. 4.ed. São Paulo, Artes Médicas, 1998.

37. FRYKHOLM, A. Angular measurements in orthopantomography. Dentomaxillofac. Radiol., v.6, n.2, p.77-81, 1977.

38. GARDINER, J.H.; MILLS, K.M. Panoramic X-ray techniques in orthodontic diagnosis. Orthodontist, v.3, p.12-7, 1971.

39. GARINO, R.R. Sistema dentário. In: APRILE, H.; FIGUN, M.E.; GARINO, R.R. Anatomia odontologica orocervicofacial. 5. ed. Buenos Aires, El Ateneo, 1971. Cap.8, p.302-516.

40. GILBERT, S.G. Orthodontics and the panorex X-ray. Bul. Philadelphia Co. D. Soc., v.28, p.11-5, 1962. 
41. GLICKMAN, I. Principios de oclusion. In:

Periodontologia clínica. 4.ed. México, Interamericana, 1974. Cap. 52, p.808-33.

42. GOLDMAN, H.M.; COHEN, D.W. Anatomia e histologia. In:_. Periodontia. 6.ed. Rio de Janeiro, Guanabara Koogan, 1983. Cap.1, p.1-56.

43. GRABER, T.M. Panoramic radiography in dentistry. L. Canad. dent. Ass., v.31, n.3, p.158-73, 1965.

44. GRABER, T.M. Postmortems in posttreatment adjustments. Amer. J. Orthodont., v.52, n.5, p.311-52, 1966.

45. GRABER, T.M. Panoramic radiography. Angle Orthodont., v.36, n.4, p.293-311, 1966.

46. GRABER, T.M. Panoramic radiography in orthodontic diagnosis. Amer. J. Orthodont., v.53, n.11, p.799-821, 1967.

47. GUIMARÃES, L. et al. Estudo de dentes supranumerários na região anterior. Rev. bras. Odont., v.49, n.3, p.34-7, 1992. 
48. HATASAKA, H.H. A radiographic study of roots in extraction sites. Angle Orthodont., v.46, n.1, p.64-8, 1976.

49. HAUCK, R.M. Documentation of tooth movement by means of panoral radiography. Amer. J. Orthodont., v.57, n.4, p.386-92, 1970.

50. HOLDAWAY, R.A. Bracket angulation as applied to the edgewise appliance. Angle Orthodont., v.22, n.4, p.227$36,1952$.

51. HOUSTON, W.J.B. The analysis of errors in orthodontic measurements. Amer. J. Orthodont., v.83, n.5, p.38290, 1983.

52. INTERLANDI, S. Ortodontia mecânica do arco de canto. Introdução à técnica. São Paulo, Sarvier, 1986.

53. ISHIKAWA, F. et al. Orthodontic applications of panoramic radiography with panorex. Ц. Jap. Orthodont. Soc., v.27, n.1, p.151-6, 1968. 
54. JAGER, A.; KABARITY, A.; SINGELMANN, C. Evaluation of orthodontic treatment with early extraction of four second molars. Ц. Orofac. Orthop., v.58, n.1, p.30-43, Feb. 1997.

55. KANE, E.G. Panoramic radiology and clinical orthodontic research. .. Missouri D. Ass., v.44, p.15-8, 1964.

56. KANE, E.G. A cephalostat for panoramic radiography. Angle Orthodont., v.37, n.4, p.325-33, 1967.

57. KITE, O.W. et al. Radiation and image distortion in the panorex X-ray unit. Oral Surg., v.15, n.10, p.1201-10, 1962.

58. LANGLAND, O.E.; SIPPY, F.H. Anatomic structures as visualized on the orthopantomogram. Oral Surg., v.26, n.4, p.475-84, 1968.

59. LARHEIM, T.A.; SVANAES, D.B. Reproducibility of rotational panoramic radiography: mandibular linear dimensions and angles. Amer. J. Orthodont. Dentofac. Orthop., v.90, n.1, p.45-51, 1986. 
60. LEE, B.W. The force requirements for tooth movement. Part II: Uprighting and root torque. Austr. Orthodont. L., v.14, n.1, p.34-9, 1995.

61. LIU, Y.T.; GRAVELY, J.F. The reliability of the "ortho grid" in cephalometric assessment. Brit. J. Orthodont., v.8, p.21-7, 1991.

62. LUCCHESI, M.V.; WOOD, R.E.; NORTJÉ, C.J. Suitability of the panoramic radiograph for assessment of mesiodistal angulation of teeth in the buccal segments of the mandible. Amer. J. Orthodont. Dentofac. Orthop., v.94, n.4, p.303-10, 1988.

63. LUND, T.M.; MANSON-HING, L.R. Relations between tooth positions and focal troughs of panoramic machines. Oral Surg., v.40, n.2, p.285-93, 1975.

64. MATILLA, K.; ALTONEN, M.; HAAVIKKO, K. Determination of the gonial angle from the orthopantomogram. Angle Orthodont., v.47, n.2, p.107-10, 1977.

65. MAYORAL, G. Treatment results with light wires studied by panoramic radiography. Amer. J. Orthodont., v.81, n.6, p.489-97, 1982. 
66. MINARELLI, A.M.; RAMALHO, L.R.T. Posição do forame da mandíbula em função do crescimento: estudo antropométrico em radiografias de crianças. $\underline{\text { Rev. bras. }}$ Cienc. Morfol., v.6, n.2, p.100-4, 1989.

67. MITCHELL, L.D. Panoramic roentgenography. Ł. Amer. dent. Ass., v.66, p.777-86, 1963.

68. MLYNARSKA-ZDUANIAK, E. Angles of inclination of the axes of teeth and buds of permanent teeth in pantomograms in normal occlusion in the early period of tooth exchange. Czas. Stomatol., v.36, n.7, p.541-6, 1983.

69. NELSEN, R.J.; KUMPULA, J.W. Panographic radiography. L. dent. Res., v.31, n.2, p.158-65, 1952.

70. PAATERO, Y.V. A new tomographical method for radiographing curved outer surfaces. Acta Radiol., v.32, p. 177-84, 1948.

71. PAATERO, Y.V. Pantomography in theory and use. Acta Radiol., v.41, p.321-35, 1954.

72. PAATERO, Y.V. Pantomography and orthopantomography. Oral Surg., v.14, n.8, p.947-53, 1961. 
73. PHILLIP, R.G.; HURST, R.V.V. The cant of the occlusal plane and distortion in the panoramic radiograph. Angle Orthodont., v.48, n.4, p.317-23, 1978.

74. PHILLIPS, J.E. Principles and function of the orthopantomograph. Oral Surg., v.24, n.1, p.41-9, 1967.

75. PICOSSE, M. Oclusão dentária. In: - Anatomia dentária. 4.ed. São Paulo, Sarvier, 1990. Cap.5, p.93110.

76. PINTO, R.H.R. Avaliação radiográfica da localização do forame mental em diferentes técnicas radiográficas como recurso complementar para planejamento em implantodontia. São Paulo, 1998. 85p. Dissertação (Mestrado) - Faculdade de Odontologia, Universidade de São Paulo.

77. RENFROE, E.W. Construction of the basic appliance. In:

Edgewise. Philadelphia, Lea \& Febiger, 1975. Cap. 2, p.65-125. 
78. RICHARDSON, J.E.; LANGLAND, O.E.; SIPPY, F.H. A cephalostat for the orthopantomograph. Oral Surg., v.27, n.5, p.642-6, 1969.

79. ROCKE, R.T. 1972 apud HATASAKA, H.H. ${ }^{48}$ p.64.

80. ROWSE, C.W. Notes on interpretation of the orthopantomogram. Brit. dent. L., v.130, p.425-34, 1971.

81. RUSHTON, V.E.; HORNER, K.; WORTHINGTON, H.V. The quality of panoramic radiographs in a sample of general dental practices. Brit. dent. J., v.186, n.12, p.630-3, 1999.

82. SAMAWI, S.S.B.; BURKE, P.H. Angular distortion in the orthopantomogram. Brit. J. Orthodont., v.11, p.100-7, 1984.

83. SANDLER, P.J. Reproducibility of cephalometric measurements. Brit. J. Orthodont., v.15, p.105-10, 1988.

84. SICHER, H.; DuBRUL, E.L. The víscera of head and neck. In: . Oral. anatomy. 5.ed. Saint Louis, Mosby, 1970. Cap.4, p.174-296. 
85. STAGGERS, J.A.; GERMANE, N.; FORSTON, W.M. A comparison of the effects of first premolar extractions on third molar angulation. Angle Orthodont., v.62, n.2, p.135-8, 1992.

86. STRANG, R.H.W. Factors associated with successful orthodontic treatment. Amer. J. Orthodont., v.38, n.10, p.790-800, 1952.

87. TANAKA, E.E. Estudo comparativo entre os aspectos clínicos, radiográficos transcranianos e tomográficos computadorizados em pacientes com disfunções crânio-mandibulares. São Paulo, 1996. $\quad$ 77p. Dissertação (Mestrado) - Faculdade de Odontologia, Universidade de São Paulo.

88. TAVANO, O. et al. Determinação de linhas de referência para medições angulares em radiografias ortopantomográficas. Odont. mod., v.16, n.9, p.22-5, 1989.

89. TUVERSON, D.L. Anterior interocclusal relations. Amer. J. Orthodont., v.78, n.4, p.361-70, 1980. 
90. URSI, W.J.S. Avaliação das inclinações axiais mesiodistais dos dentes superiores e inferiores, em uma amostra de oclusão normal, não tratada ortodonticamente, utilizando radiografias ortopantomográficas obtidas em diferentes aparelhos. Bauru, 1989. 99p. Dissertação (Mestrado) - Faculdade de Odontologia de Bauru, Universidade de São Paulo.

91. URSI, W.J.S. et al. Assessment of mesiodistal axial inclination through panoramic radiography. L. clin. Orthodont., v.24, n.3, p.166-73, 1990.

92. VIGORITO, J.W. Introdução à mecânica ortodôntica com aparelhos fixos. In: - Ortodontia clínica preventiva. São Paulo, Panamed, 1984. Cap. 8, p.255-93.

93. WATSON, W. apud BLACKMAN, S. ${ }^{16}$ p. 408.

94. WHEELER, R.C. The arrangement of the teeth and occlusion. In: . A textbook of dental anatomy and physiology. 4.ed. Philadelphia, Saunders Company, 1965. Cap. 16, p. 365-412.

95. WILLIAMS, R. Eliminating lower retention. L. clin. Orthodont., v.19, n.5, p.342-9, 1985. 
96. YOUNG, J. Outline of oral and dental anatomy. New York, McGraw-Hill, 1964.

97. ZACH, G.A.; LANGLAND, O.E.; SIPPY, F.H. The use of the orthopantomograph in longitudinal studies. Angle Orthodont., v.39, n.1, p.42-50, 1969. 


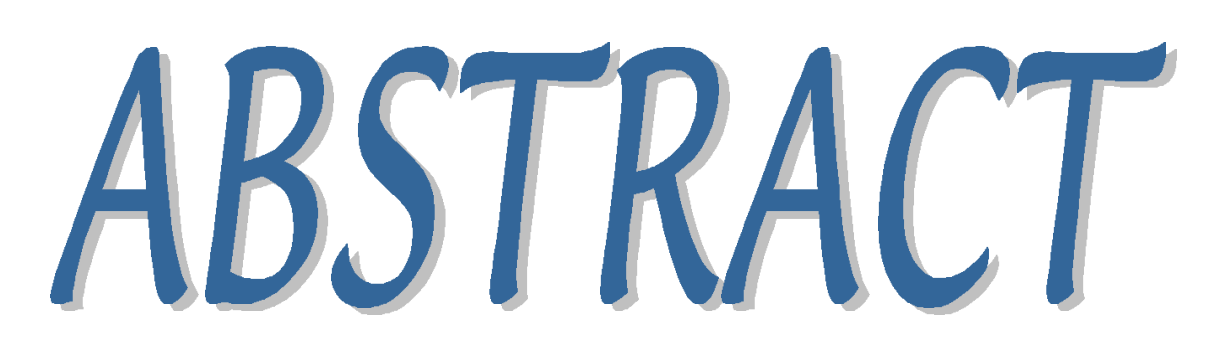




\section{ABSTRACT}

Ortopantomograph study of anterior teeth axial inclinations, comparing patients orthodontically treated and subjects with untreated normal occlusion.

The objective of this investigation was to evaluate, through panoramic radiographs, the mesiodistal axial inclination of the upper anterior teeth and lower cuspids at the beginning and at the end of orthodontic treatment. The experimental sample consisted of 40 patients ( 20 males and 20 females) treated orthodontically by the simplified standard edgewise technique without extractions. From each patient a panoramic radiography was taken at the beginning (T1) and at the end (T2) of treatment. The mean values of the mesiodistal axial inclination at T1 were compared with the mean values at $\mathrm{T} 2$ and both were compared to the mesiodistal axial inclination of a normal control sample. Results showed that the mesiodistal axial inclinations of the upper anterior teeth and the lower cuspids at the beginning of treatment were different from those observed in a normal occlusion in $50 \%$ of the evaluated teeth. However, the inclinations at the end of treatment, were, in most instances, consistent with the normal anatomical configuration. In addition, the panoramic radiographs proved to be an important tool for this purpose. 